\title{
NEVADA TEST SITE WATER-SUPPLY WELLS
}

\author{
Prepared by \\ David Gillespie, Dee Donithan, and Paul Seaber
}

Submitted to

Nevada Operations Office

U.S. Department of Energy

MAY 1996
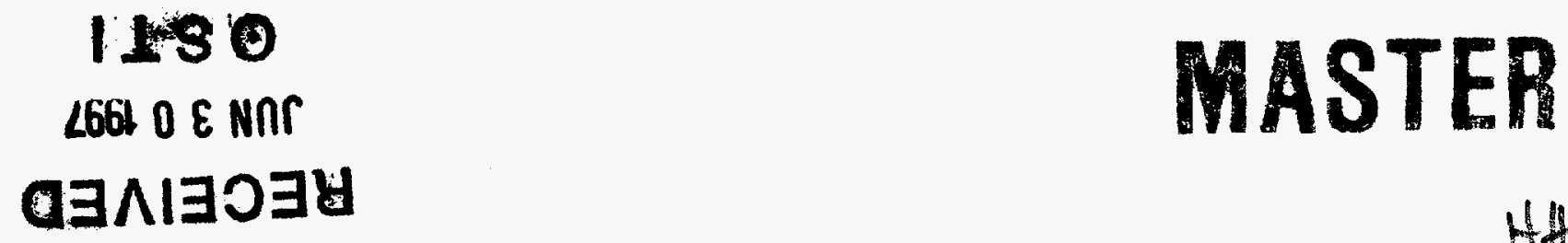


\section{DISCLAMMER}

Portions of this document may be illegible in electronic image products. Images are produced from the best available original document. 
This report was prepared as an account of work sponsored by the United States Government. Neither the United States nor the United States Department of Energy, nor any of their employees, makes any warranty, express or implied, or assumes any legal liability or responsibility for the accuracy, completeness or usefulness of any information, apparatus, product or process disclosed, or represents that its use would not infringe privately owned rights. Reference herein to any specific commercial product, process, or service by trade name, mark, manufacturer, or otherwise, does not necessarily constitute or imply its endorsement, recommendation, or favoring by the United States Government or any agency thereof. The views and opinions of authors expressed herein do not necessarily state or reflect those of the United States Government or any agency thereof.

This report has been reproduced directly from the best available copy.

Available to DOE and DOE contractors from the Office of Scientific and Technical Information, P.O. Box 62, Oak Ridge, TN 37831; prices available from (423) 576-8401.

Available to the public from the National Technical Information Service, U.S. Department of Commerce, 5285 Port Royal Rd., Springfield, VA 22161. 


\title{
NEVADA TEST SITE WATER-SUPPLY WELLS
}

\author{
Prepared by \\ David Gillespie, Dee Donithan, and Paul Seaber \\ Water Resources Center \\ Desert Research Institute \\ University and Community College System of Nevada
}

Publication No. 45138

\section{Submitted to}

Nevada Operations Office

U.S. Department of Energy

Las Vegas, Nevada

May 1996

The work upon which this report is based was supported by the U.S. Department of Energy under Contract \#DE-AC08-90NV10845. 


\section{CONTENTS}

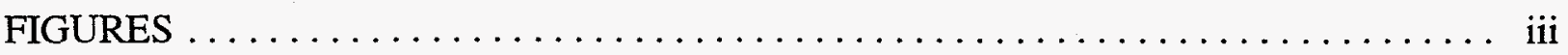

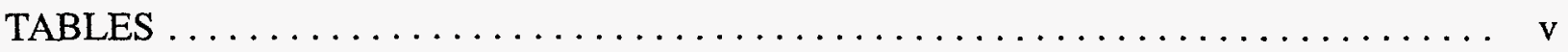

CONVERSION FACTORS AND ABBREVIATIONS $\ldots \ldots \ldots \ldots \ldots \ldots \ldots \ldots$ vi

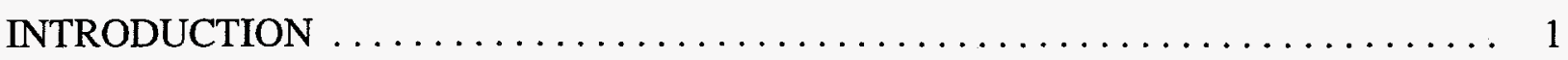

OVERVIEW OF THE GROUNDWATER REGIME ON THE NEVADA TEST SITE $\ldots . .1$

Physiography and Geology of the NTS $\ldots \ldots \ldots \ldots \ldots \ldots \ldots \ldots \ldots \ldots \ldots$

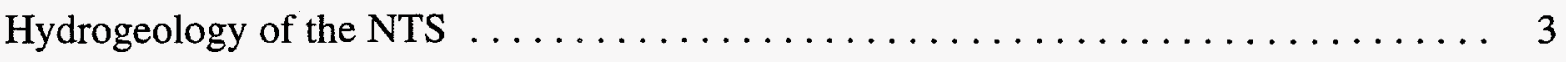

Regional Groundwater Flow Patterns at the NTS $\ldots \ldots \ldots \ldots \ldots \ldots \ldots \ldots \ldots$

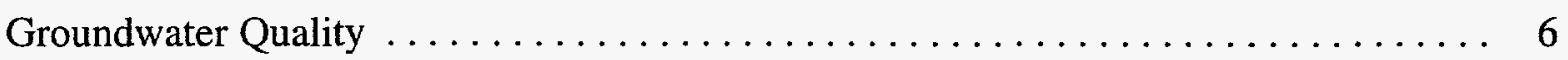

POSSIBLE SOURCES FOR CONTAMINATION OF NTS WATER SUPPLY WELLS $\ldots .6$

Underground Nuclear Tests $\ldots \ldots \ldots \ldots \ldots \ldots \ldots \ldots \ldots \ldots \ldots \ldots \ldots \ldots$

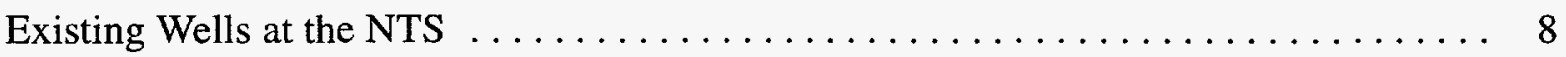

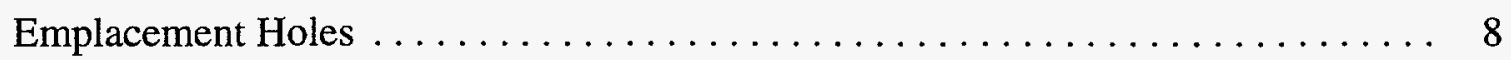

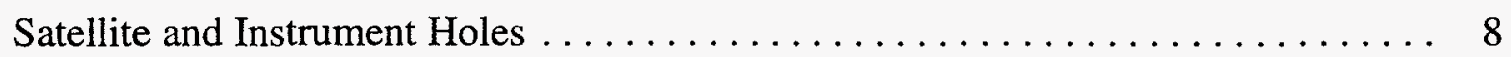

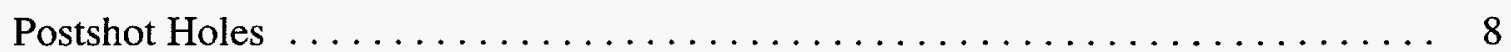

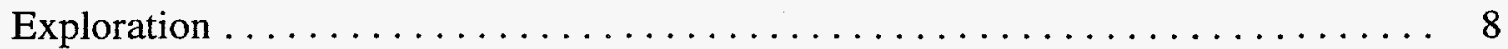

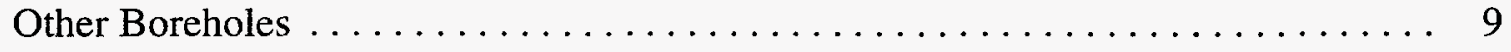

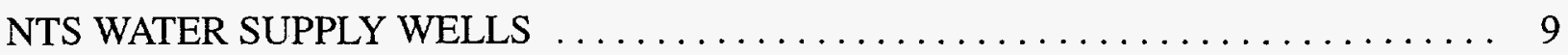

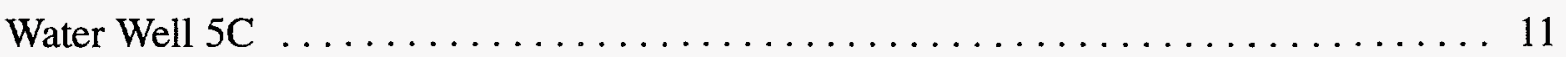

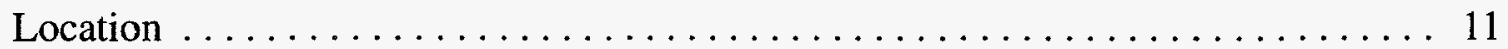

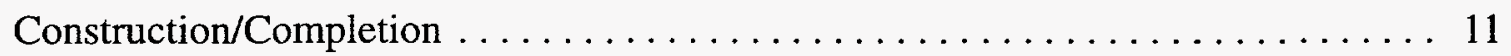

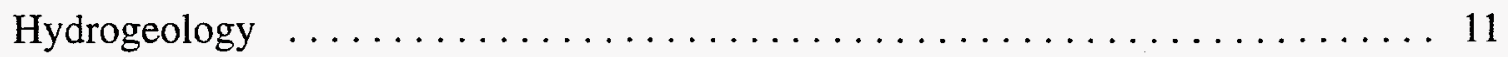

Proximity to Underground Nuclear Tests and Existing Wells $\ldots \ldots \ldots \ldots \ldots \ldots 11$

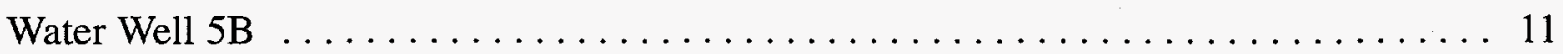

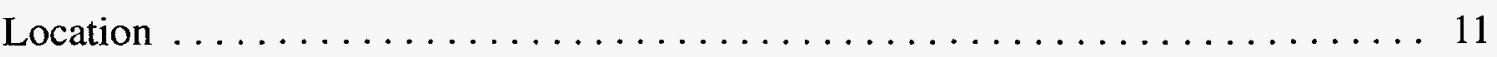

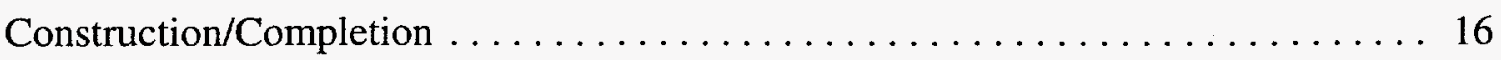

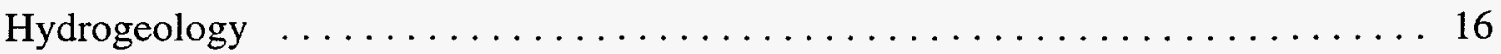

Proximity to Underground Nuclear Tests and Existing Wells $\ldots \ldots \ldots \ldots \ldots \ldots$

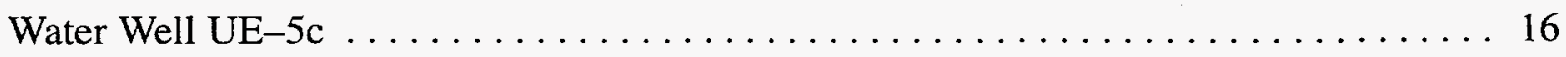

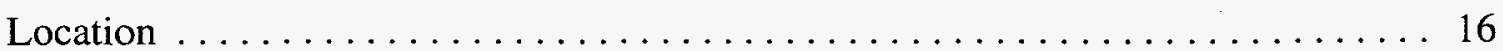

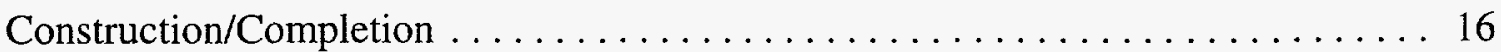

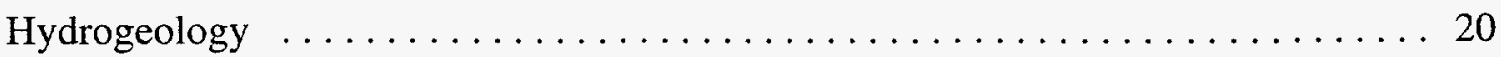

Proximity to Underground Nuclear Tests and Existing Wells $\ldots \ldots \ldots \ldots \ldots 20$

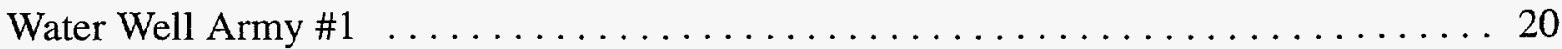

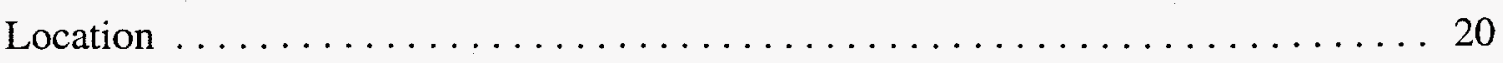

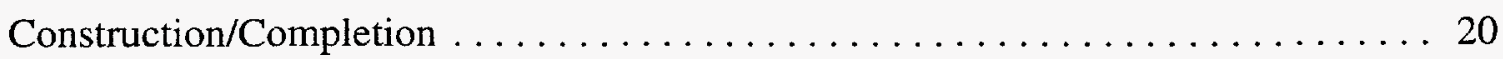




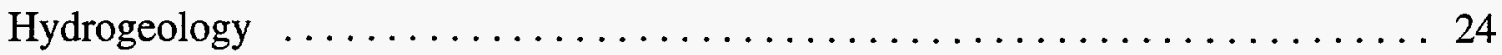

Proximity to Underground Nuclear Tests and Existing Wells $\ldots \ldots \ldots \ldots \ldots 24$

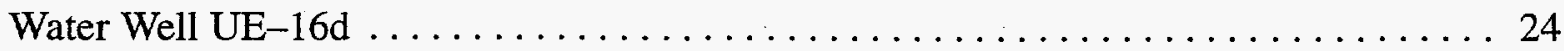

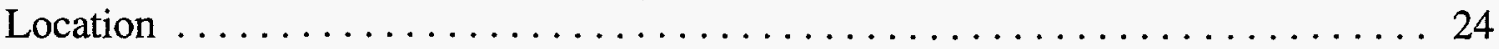

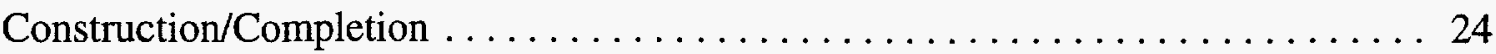

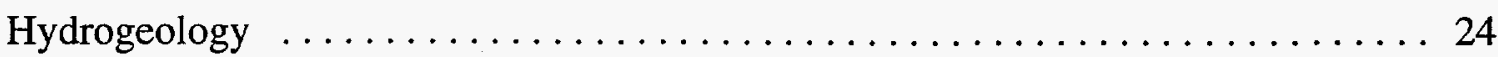

Proximity to Underground Nuclear Tests and Existing Wells $\ldots \ldots \ldots \ldots \ldots 27$

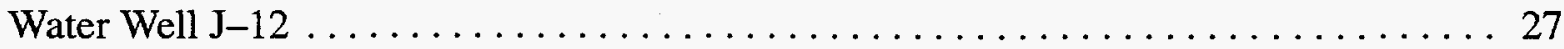

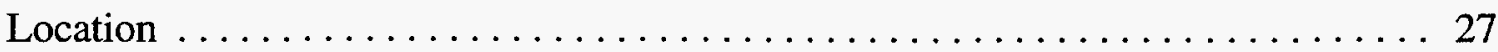

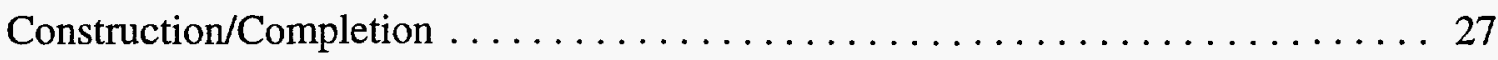

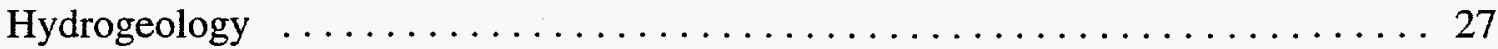

Proximity to Underground Nuclear Tests and Existing Wells . . . . . . . . . 31

Existing Water Rights Permits $\ldots \ldots \ldots \ldots \ldots \ldots \ldots \ldots \ldots \ldots \ldots \ldots \ldots \ldots \ldots \ldots \ldots \ldots \ldots$

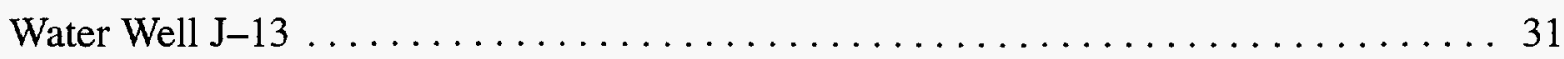

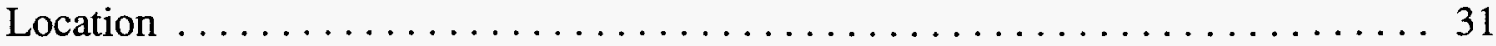

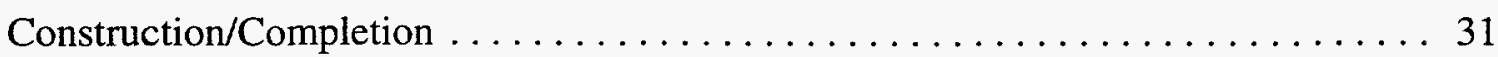

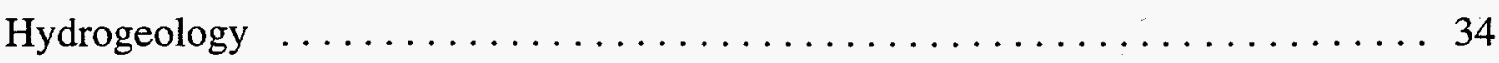

Proximity to Underground Nuclear Tests and Existing Wells ............ 34

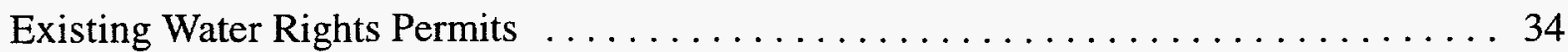

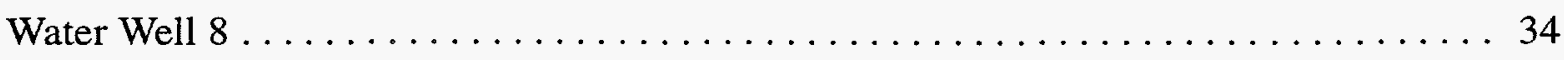

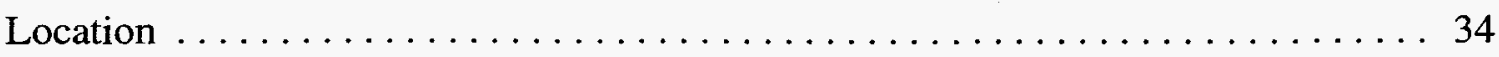

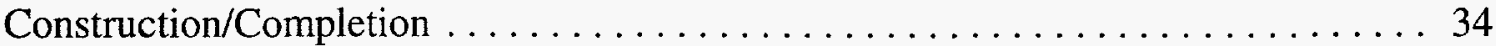

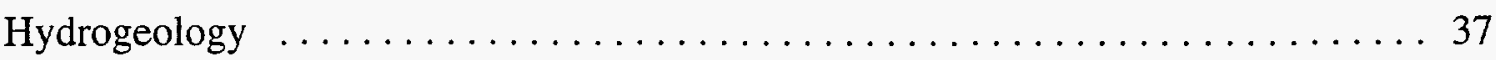

Proximity to Underground Nuclear Tests and Existing Wells . . . . . . . . 37

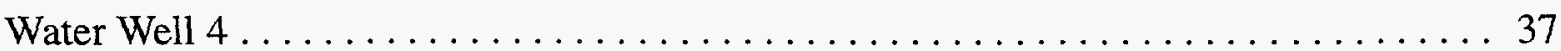

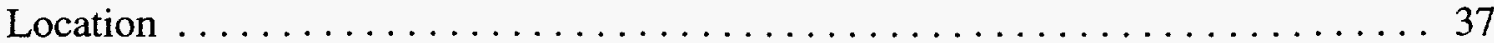

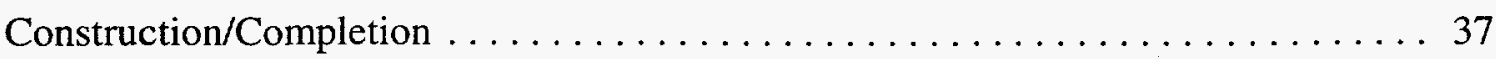

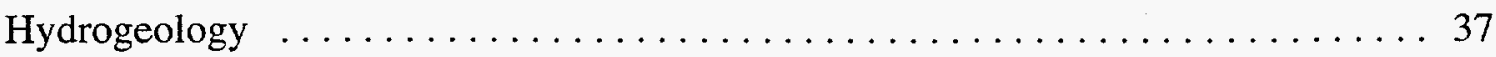

Proximity to Underground Nuclear Tests and Existing Wells ............. 40

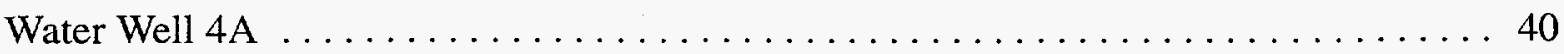

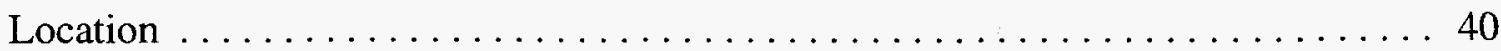

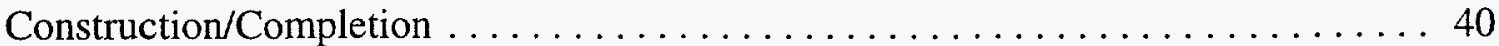

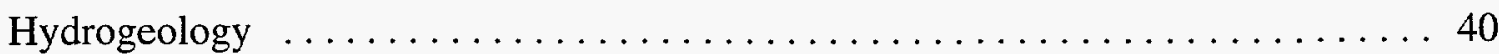

Proximity to Underground Nuclear Tests and Existing Wells $\ldots \ldots \ldots \ldots \ldots \ldots 44$

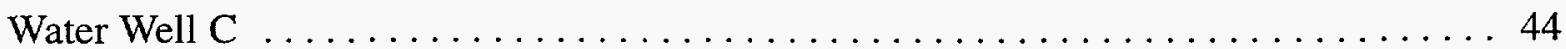

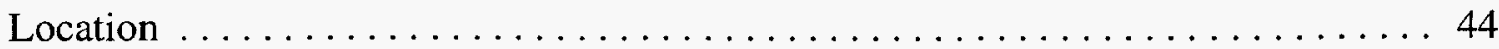

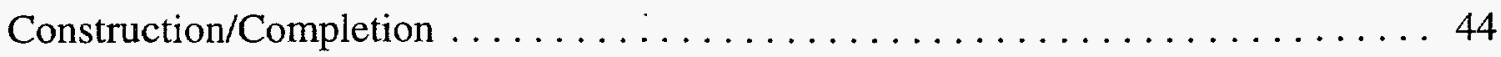

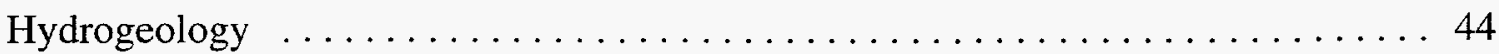


Proximity to Underground Nuclear Tests and Existing Wells . . . . . . . . 47

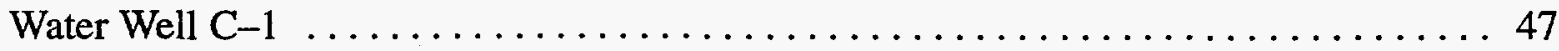

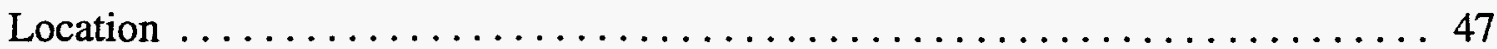

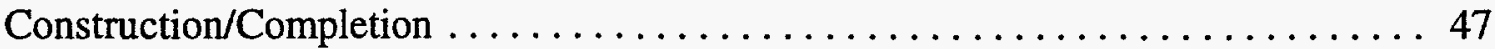

Hydrogeology $\ldots \ldots \ldots \ldots \ldots \ldots \ldots \ldots \ldots \ldots \ldots \ldots \ldots \ldots \ldots \ldots \ldots$

Proximity to Underground Nuclear Tests and Existing Wells . . . . . . . . . . 47

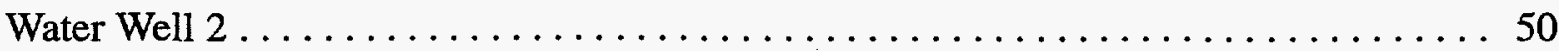

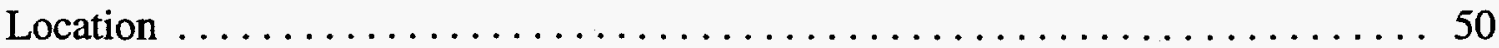

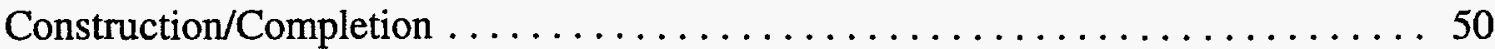

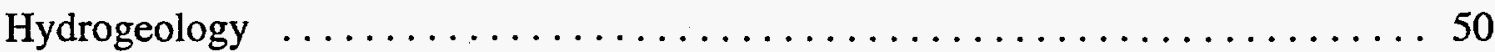

Proximity to Underground Nuclear Tests and Existing Wells . . . . . . . . . 50

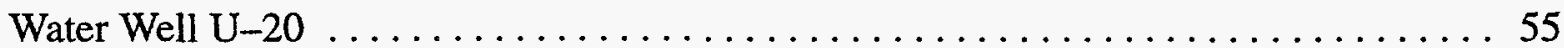

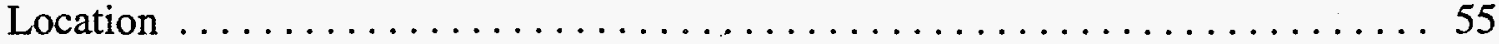

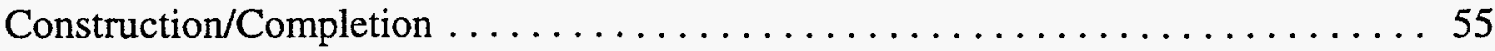

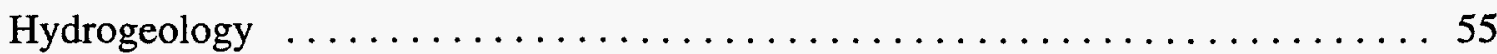

Proximity to Underground Nuclear Tests and Existing Wells $\ldots \ldots \ldots \ldots \ldots 5$

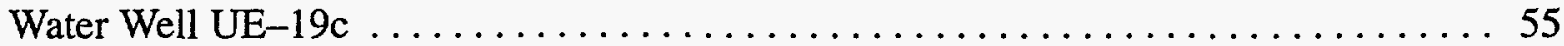

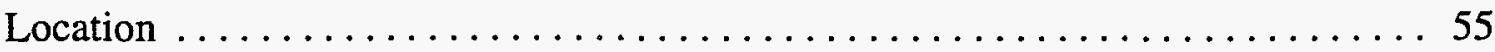

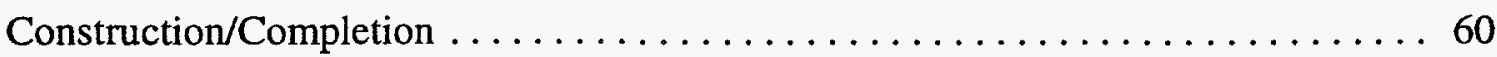

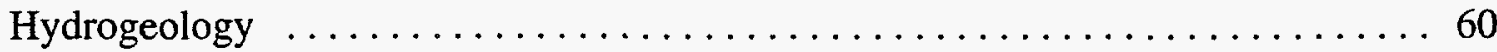

Proximity to Underground Nuclear Tests and Existing Wells . . . . . . . . . . 60

REFERENCES ................................. 65

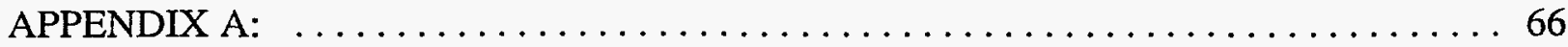

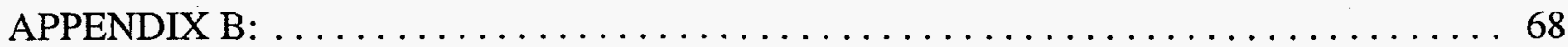

\section{FIGURES}

1. Physiographic features at the Nevada Test Site. $\ldots \ldots \ldots \ldots \ldots \ldots \ldots \ldots \ldots$

2. Major rock types at the Nevada Test Site. . . . . . . . . . . . . . . 3

3. Composite potentiometric surface and hydrographic subbasins at the Nevada Test Site. . . . . . . . . . . . . . . . . . . . . . . . . . . . 5

4. Underground nuclear testing locations at the Nevada Test Site. . . . . . . . . . 7

5. Location of NTS water-supply wells. $\ldots \ldots \ldots \ldots \ldots \ldots \ldots \ldots \ldots \ldots \ldots \ldots$

6. Well construction and lithology at Water Well $5 \mathrm{C} \ldots \ldots \ldots \ldots \ldots \ldots \ldots$

7. Water Well $5 \mathrm{C}$ water quality $($ Stiff-diagram) $\ldots \ldots \ldots \ldots \ldots \ldots \ldots \ldots \ldots$ 
8. Map showing relative locations of Water Well $5 \mathrm{C}$, Water Well $5 \mathrm{~B}$, and Water Well 5A.................................... 15

9. Well construction and lithology at Water Well 5 B. . . . . . . . . . . . . 17

10. Water Well $5 B$ water quality $($ Stiff-diagram) $\ldots \ldots \ldots \ldots \ldots \ldots \ldots \ldots \ldots \ldots$

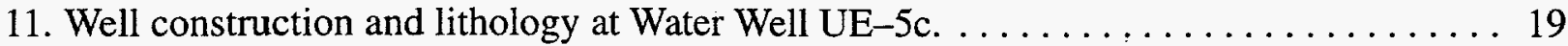

12. Water Well UE-5c water quality $($ Stiff-diagram $) \ldots \ldots \ldots \ldots \ldots \ldots \ldots \ldots$

13. Map showing relative locations of Water Well UE-5c, U-5e, RNM \#1,

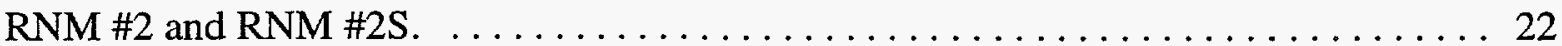

14. Well construction and lithology at Water Well Army \#1. . . . . . . . . . . 23

15. Water Well Army \#1 water quality (Stiff-diagram) $\ldots \ldots \ldots \ldots \ldots \ldots \ldots \ldots$

16. Well construction and lithology at Water Well UE-16d. . . . . . . . . . . 26

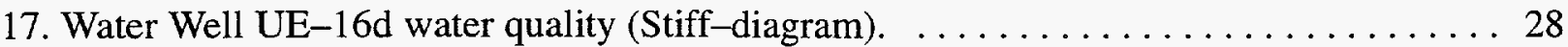

18. Map showing relative locations of Water Well UE-16d, UE-16c, UE-17a,

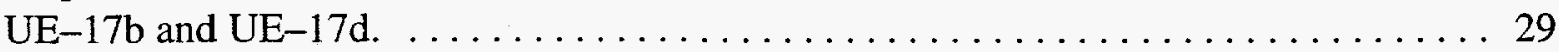

19. Well construction and lithology at Water Well $\mathrm{J}-12 \ldots \ldots \ldots \ldots \ldots \ldots \ldots$

20. Water Well J-12 water quality (Stiff-diagram) $\ldots \ldots \ldots \ldots \ldots \ldots \ldots \ldots \ldots$

21. Well construction and lithology at Water Well $\mathrm{J}-13 \ldots \ldots \ldots \ldots \ldots \ldots \ldots$

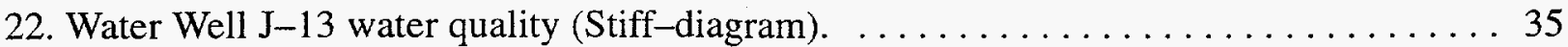

23. Well construction and lithology at Water Well $8 . \ldots \ldots \ldots \ldots \ldots \ldots \ldots \ldots$

24. Water Well 8 water quality $($ Stiff - diagram) $\ldots \ldots \ldots \ldots \ldots \ldots \ldots \ldots$

25. Well construction and lithology at Water Well $4 . \ldots \ldots \ldots \ldots \ldots \ldots \ldots$

26. Water Well 4 water quality $($ Stiff-diagram) $\ldots \ldots \ldots \ldots \ldots \ldots \ldots \ldots \ldots \ldots \ldots$

27. Map showing relative locations of Water Well 4, Water Well 4A,

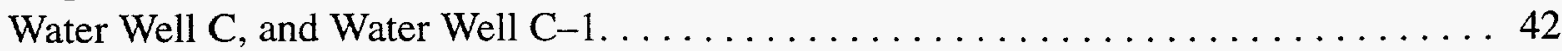

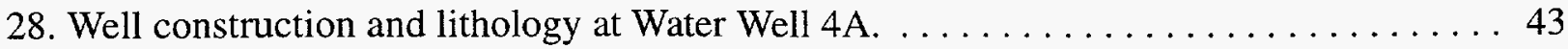

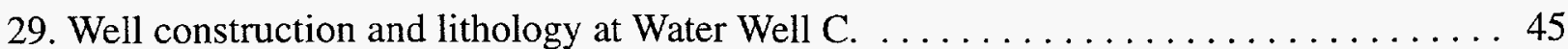

30. Water Well $\mathrm{C}$ water quality $($ Stiff-diagram) $\ldots \ldots \ldots \ldots \ldots \ldots \ldots \ldots \ldots \ldots$

31. Well construction and lithology at Water Well $\mathrm{C}-1 . \ldots \ldots \ldots \ldots \ldots \ldots$ 
32. Water Well C-1 water quality (Stiff-diagram) $\ldots \ldots \ldots \ldots \ldots \ldots \ldots \ldots \ldots$

33. Well construction and lithology at Water Well $2 . \ldots \ldots \ldots \ldots \ldots \ldots \ldots \ldots \ldots$

34. Water Well 2 water quality (Stiff-diagram). $\ldots \ldots \ldots \ldots \ldots \ldots \ldots \ldots \ldots \ldots \ldots \ldots \ldots \ldots \ldots$

35. Map showing relative locations of Water Well 2, U-2ax,UE-8d, UE-8f,

UE-8i, UE-8h, and Jangle Test Hole \#A2 $\ldots \ldots \ldots \ldots \ldots \ldots \ldots \ldots \ldots \ldots$

36. Lithologic cross section showing relationship between Water Well 2

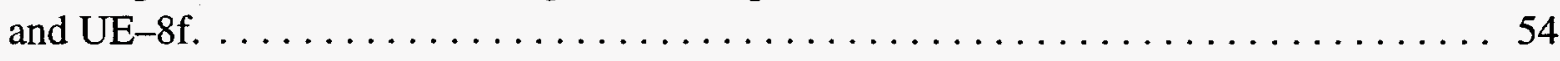

37. Well construction and lithology at Water Well $U-20 . \ldots \ldots \ldots \ldots \ldots \ldots \ldots$

38. Water Well U-20 water quality (Stiff-diagram) $\ldots \ldots \ldots \ldots \ldots \ldots \ldots \ldots \ldots \ldots \ldots \ldots \ldots$

39. Map showing relative locations of Water Well U-20, U-20ac, U-20a, U-20b, U-20n, U-20bf, U-20bd, U-20ay, U-20ai, UE-20n\#1 and UE-20bh\#1 . . . . . . . 58

40. Lithologic cross-section showing relationship between U-20 Water and U-20bd.

41. Well construction and lithology at Water Well UE-19c. ................ 61

42. Water Well UE-19c water quality (Stiff-diagram) $\ldots \ldots \ldots \ldots \ldots \ldots \ldots \ldots \ldots \ldots \ldots \ldots$

43. Map showing relative locations of Water Well UE-19c and U-19c. $\ldots \ldots \ldots \ldots \ldots 6$

44. Lithologic cross section showing relationship between Water Well UE-19c

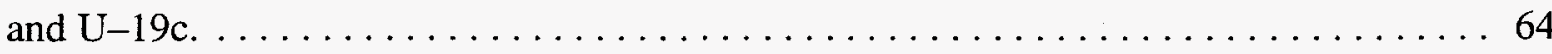

TABLES

1. Nevada Test Site Water-Supply Wells $\ldots \ldots \ldots \ldots \ldots \ldots \ldots \ldots \ldots \ldots \ldots \ldots \ldots \ldots$

2. Hydrostratigraphic Classification of Principal Lithologic Units at the Nevada Test Site

3. Summary of Construction, Lithologic, and Hydrologic Characteristics of NTS

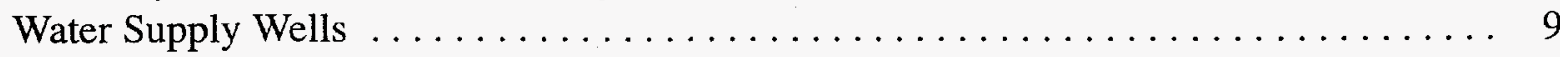

4. Major Ion Chemistry from NTS Water-Supply Wells $\ldots \ldots \ldots \ldots \ldots \ldots \ldots \ldots$ 


\section{CONVERSION FACTORS AND ABBREVIATIONS}

Units of measure used in this report may be converted to International System (metric) units by using the following factors:

$\begin{array}{ll}\text { Multiply } & \underline{\text { By }} \\ \text { mile } & 1.609344 \\ \text { foot (ft) } & 0.3048 \\ \text { inch (in) } & 2.54 \\ \text { inch (in) } & 25.4 \\ \text { gallon (gal) } & 0.003785434\end{array}$

To Obtain

$\mathrm{km}$

meter $(\mathrm{m})$

centimeter $(\mathrm{cm})$

millimeter $(\mathrm{mm})$

cubic meters $\left(\mathrm{m}^{3}\right)$ 


\section{INTRODUCTION}

A total of 15 water-supply wells (Table 1) are currently being used at the Nevada Test Site (NTS). The purpose of this report is to bring together the information gleaned from investigations of these water-supply wells. This report should serve as a reference on well construction and completion, static water levels, lithologic and hydrologic characteristics of aquifers penetrated, and general water quality of water-supply wells at the NTS.

Possible sources for contamination of the water-supply wells are also evaluated. Existing wells and underground nuclear tests conducted near (within 25 meters (m)) or below the water table within 2 kilometers $(\mathrm{km})$ of a water-supply well were located and their hydrogeologic relationship to the water-supply well determined.

TABLE 1. NEVADA TEST SITE WATER-SUPPLY WELLS.

\begin{tabular}{lll}
\hline \hline Water Well 5C & Water Well J-12 & Water Well C \\
Water Well 5B & Water Well J-13 & Water Well C-1 \\
Water Well UE-5c & Water Well 8 & Water Well 2 \\
Water Well Army \#1 & Water Well 4 & Water Well U-20 \\
Water Well UE-16d & Water Well 4A & Water Well UE-19c \\
\hline
\end{tabular}

\section{OVERVIEW OF THE GROUNDWATER REGIME ON THE NEVADA TEST SITE}

\section{Physiography and Geology of the Nevada Test Site}

The NTS is located in southern Nevada and lies within the Basin and Range physiographic province. The topography of the NTS is composed of four major basins, three large mesas, and a number of north-south-trending mountain ranges. The four major basins, or valleys, are located in the eastern and southern areas and are known as Frenchman, Yucca and Jackass flats, and Mercury Valley. The minimum elevations of these basins (above mean sea level) are 1200, 1000, 1100, and $1000 \mathrm{~m}$, respectively. The three large mesas are Pahute Mesa (2256 m), Buckboard Mesa (1848 m), and Rainier Mesa (2324 m). The major mountain ranges on the NTS include the Belted Range (2354 $\mathrm{m})$, Mercury Ridge (1608 m), and the Halfpint Range (1539 m). Isolated mountains such as Skull Mountain (1828 m), Shoshone Mountain (2154 m), and Yucca Mountain (1930 m) are also present on the NTS. The locations of these features are shown in Figure 1.

The major geologic units of the NTS can be classified into three types: (1) complexly folded and faulted sedimentary rocks of Paleozoic age, (2) volcanic tuffs and lavas of Tertiary age, and (3) Tertiary and Quaternary alluvium (Figure 2). The sedimentary rocks of Paleozoic age are hundreds to thousands of meters thick and are comprised primarily of carbonate rocks in the lower and upper sections, which are separated by a thick sequence of clastic rocks (shale and quartzite). These Paleozoic-age sediments have undergone several deformational events, resulting in a series of north-south-oriented thrust faults, accompanied by complex folding and normal faulting. 


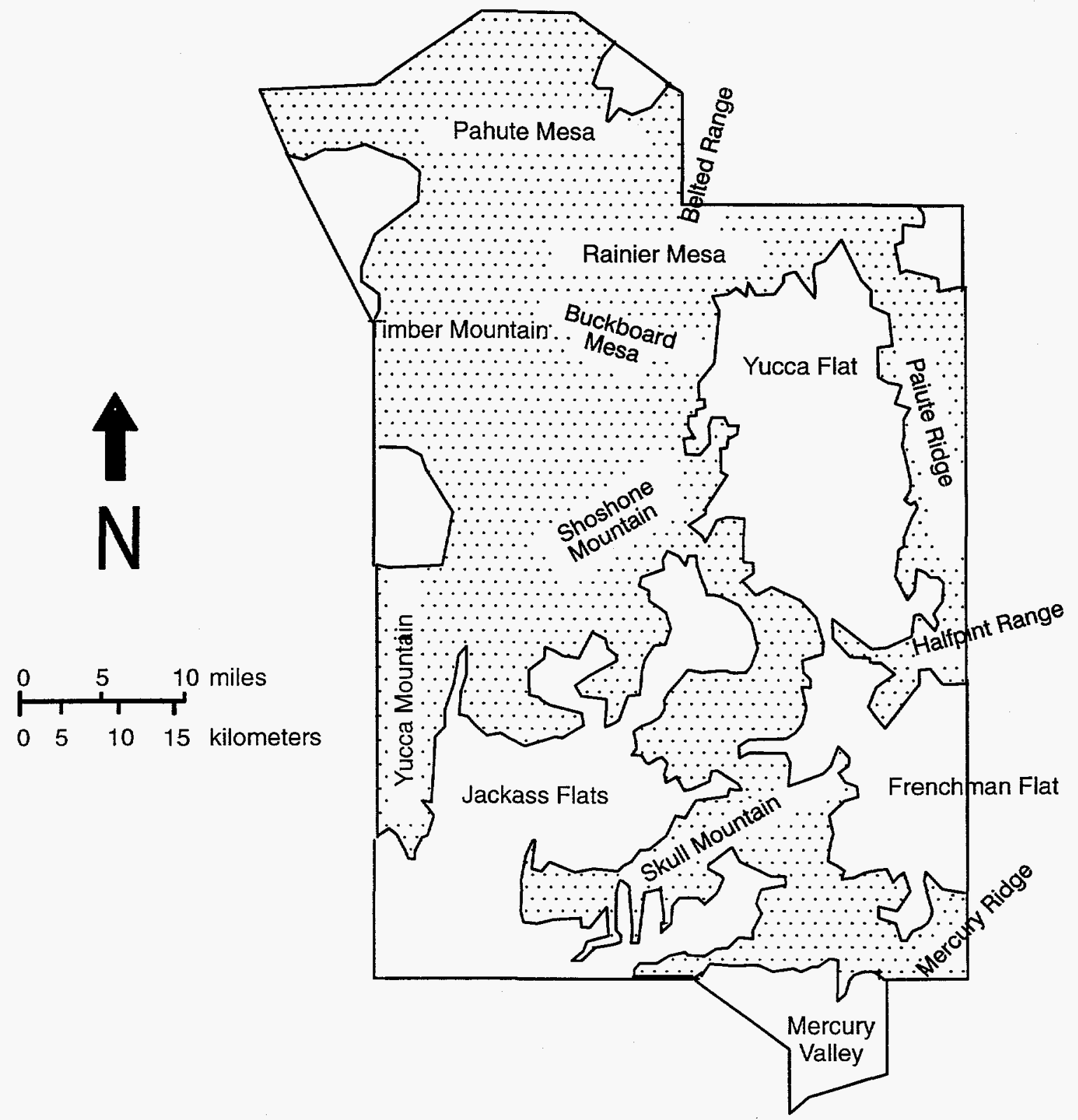

Figure 1. Physiographic features at the Nevada Test Site.

The volcanic units of Tertiary age are predominantly rhyolitic tuffs ejected from volcanic centers, primarily Silent Canyon and Timber Mountain calderas, located in the northwestern portion of the NTS. The aggregate thickness of these volcanic rocks is several thousand meters, however, erosion and nondeposition result in extremely variable thickness of individual units. Tertiary units have been deformed to a much lesser degree than the Paleozoic section, and are down-dropped in the valleys and tilted along steeply dipping faults of late Tertiary age. 


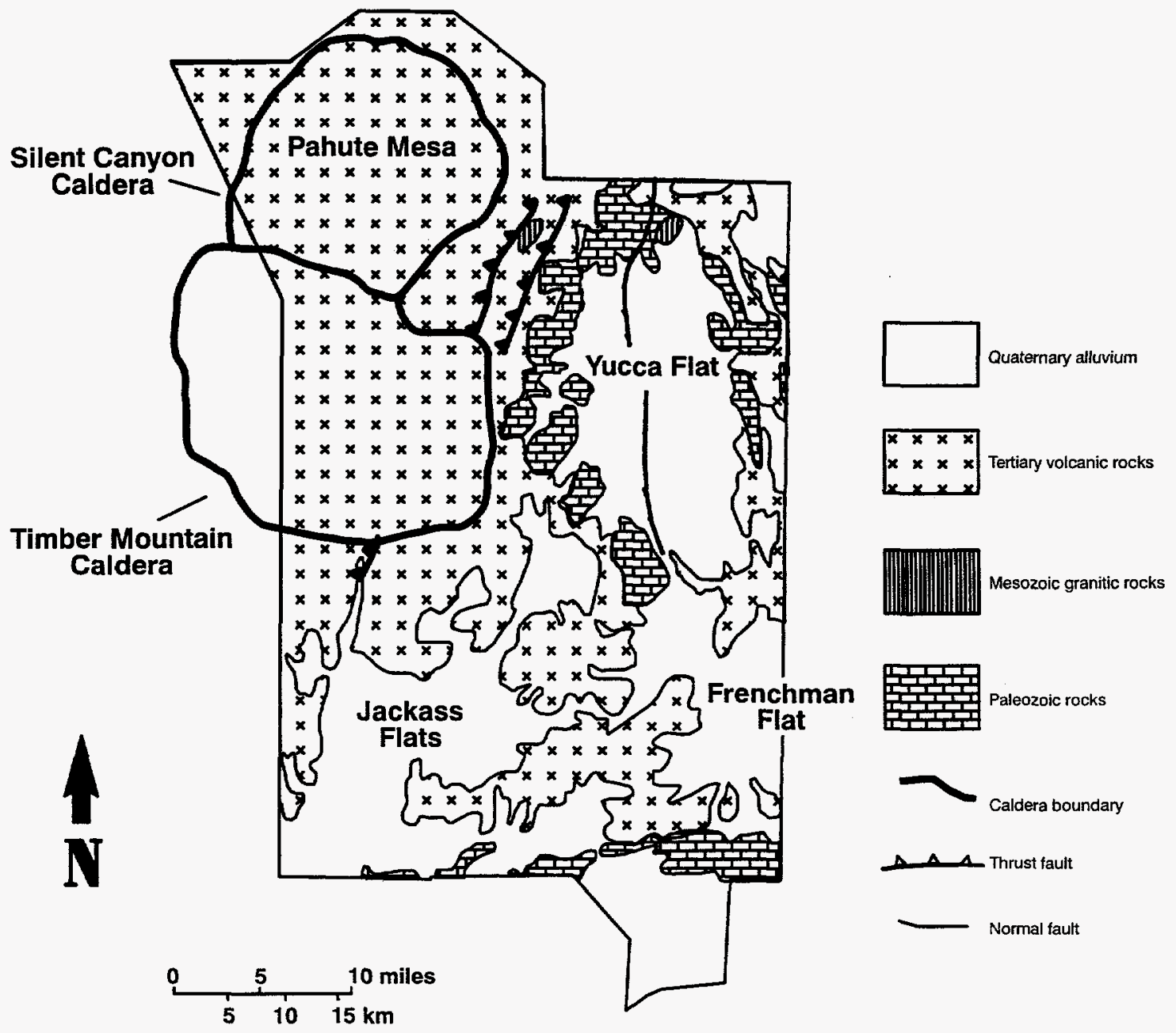

Figure 2. Major rock types at the Nevada Test Site.

Alluvial sediments are derived from the erosion of nearby mountains. These sediments are composed of Paleozoic and Tertiary rock fragments, and fill the intermontaine valleys to a maximum thickness of 600 to 900 meters. Alluvial sediments appear to be relatively undeformed with the exception of geologically recent faulting producing offsets in these materials, especially along the north-south-trending Yucca Fault in central Yucca Flat.

\section{Hydrogeology of the Nevada Test Site}

A generalized hydrostratigraphic classification of the principal lithologic units encountered at the NTS, as modified from Winograd and Thordarson (1975), is presented in Table 2. Valley fill (alluvium) is an aquifer whenever it is encountered within the saturated zone (within the deepest portions of the basin valleys), and transmits groundwater through intergranular, primary porosity/permeability. Tertiary volcanics produce aquifers in lava-flow, welded tuff, and bedded tuff intervals. Tuff aquitards occur in non-welded, and zeolitized tuff units. In general, groundwater flow within Tertiary volcanic units is dominated by fracture flow (secondary porosity/permeability). The 
more dense lava and welded tuff units contain a greater number of fractures; non-welded and zeolitized units (less dense) contain fewer or sealed fractures. Paleozoic aquifers consist of fractured carbonate units. Paleozoic aquitards consist of clastic intervals (shales and quartzites).

TABLE 2. HYDROSTRATIGRAPHIC CLASSIFICATION OF PRINCIPAL LITHOLOGIC UNITS AT THE NEVADA TEST SITE.

\begin{tabular}{|c|c|c|}
\hline Geologic Time Period & Stratigraphic Unit & Hydrogeologic Unit \\
\hline \multirow[t]{6}{*}{ Cenozoic } & Valley Fill & Valley-Fill Aquifer \\
\hline & $\begin{array}{l}\text { Basalt of Kiwi Mesa } \\
\text { Rhyolite of Shoshone Mountain } \\
\text { Basalt of Skull Mountain }\end{array}$ & Lava-Flow Aquifer \\
\hline & $\begin{array}{l}\text { Timber Mountain Tuff } \\
\text { Paintbrush Tuff }\end{array}$ & Welded Tuff Aquifer \\
\hline & Informal Bedded Tuff & Bedded Tuff Aquifer \\
\hline & Wahmonie Formation & Lava-Flow Aquitard/Tuff Aquitard \\
\hline & $\begin{array}{l}\text { Salyer Formation } \\
\text { Belted Range Tuff } \\
\text { Local Informal Units } \\
\text { Rhyolite Flows and Tuffaceous } \\
\text { Beds of Calico Hills } \\
\text { Tuff of Crater Flat } \\
\text { Lithic Ridge Tuff } \\
\text { Rocks of Pavits Spring } \\
\text { Horse Spring Formation }\end{array}$ & Tuff Aquitard \\
\hline Mesozoic & Granitic Stocks & Minor Aquitard \\
\hline \multirow[t]{3}{*}{ Paleozoic } & Tippipah Limestone & Upper Carbonate Aquifer \\
\hline & Eleana Formation & Upper Clastic Aquitard \\
\hline & $\begin{array}{l}\text { Devil's Gate Limestone } \\
\text { Nevada Formation } \\
\text { Undifferentiated Dolomite } \\
\text { Ely Springs Dolomite } \\
\text { Eureka Quartzite } \\
\text { Pogonip Group } \\
\text { Nopah Formation } \\
\text { Bonanza King Formation } \\
\text { Carrera Formation }\end{array}$ & Lower Carbonate Aquifer \\
\hline Precambrian & $\begin{array}{l}\text { Zabriskie Quartzite } \\
\text { Wood Canyon Formation } \\
\text { Stirling Quartzite } \\
\text { Johnnie Formation }\end{array}$ & Lower Clastic Aquitard \\
\hline
\end{tabular}




\section{Regional Groundwater Flow Patterns at the Nevada Test Site}

Areas of groundwater recharge, discharge, and flow on and near the NTS have been divided into three subbasins (Figure 3) which are considered part of the larger Death Valley groundwater basin (Waddell et al., 1984). Groundwater within the Ash Meadows subbasin drains from areas north and east of the NTS and flows generally southwestward towards springs at Ash Meadows, approximately $40 \mathrm{~km}$ southwest of Mercury (Winograd and Thordarson, 1975). Groundwater flow within this subbasin is thought to occur primarily in the lower carbonate aquifer. The distribution of head and direction of flow are greatly affected by the presence of low permeability rocks (lower clastic aquitard) within the subbasin (Winograd and Thordarson, 1975).

Groundwater from the majority of the western portion of the NTS flows from beneath Pahute Mesa (and possibly other areas to the north) southward, towards Alkali Flat in the central Amargosa Desert. Groundwater flow is through the valley-fill, volcanic, and lower carbonate aquifers.

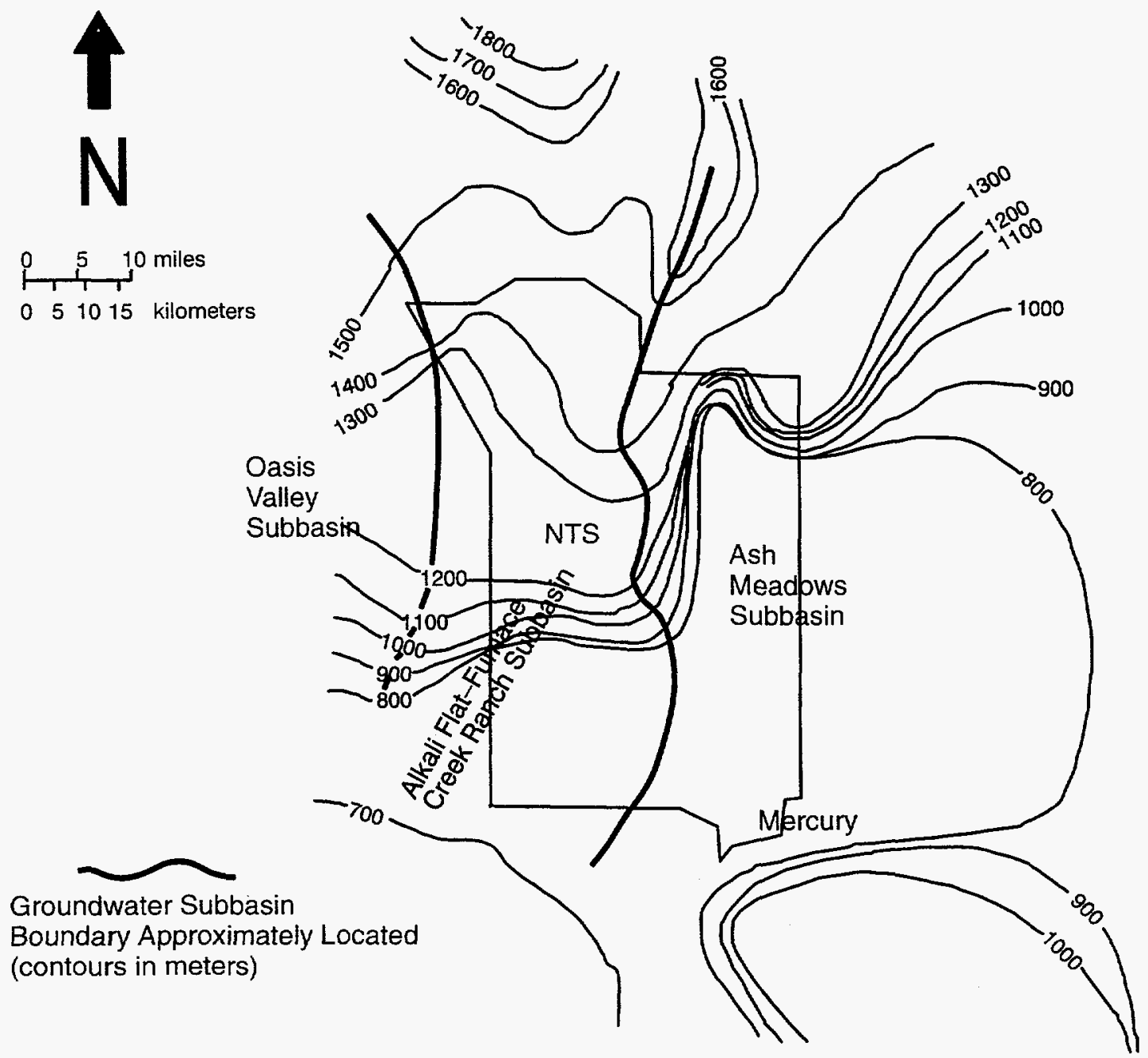

Figure 3. Composite potentiometric surface and hydrographic subbasins at the Nevada Test Site (after Waddell et al., 1984). 
Discharge occurs at Alkali Flat by evapotranspiration. Some underflow may surface at springs in Death Valley (Winograd and Thordarson, 1975).

The remaining portion of groundwater flowing from western Pahute Mesa and areas to the north is thought to move southward, beneath the western portion of the NTS, within the Oasis Valley subbasin. Discharge from this flow system occurs primarily through evapotranspiration at Oasis Valley and as underflow to the Alkali Flat-Furnace Creek Ranch subbasin (White, 1979). Groundwater flow in Pahute Mesa is primarily through interbedded volcanic rocks, which exhibit extreme contrasts in vertical and horizontal hydraulic conductivity (Blankennagel and Weir, 1973).

The boundaries of the subbasins described above have been placed at different locations by different authors and, due to the sparseness of data, are poorly defined. The average well density for the NTS (an area of approximately 43,240 square $\mathrm{km}$ ) is very low. The level of coverage sufficient for the determination of generalized regional flow patterns is not adequate to determine localized, detailed flow models required for hydrologic characterization. The paucity of wells on the NTS prohibit the determination of vital information such as: rate or direction of inter-aquifer flux, the perturbations created by localized geologic structure or nuclear testing, or the delineation of permeable and impermeable zones within individual hydrologic units.

\section{Groundwater Quality}

The interpretation of groundwater chemical analysis has been extremely valuable in developing conceptual models of groundwater flow. Schoff and Moore (1964) performed the first comprehensive studies of the chemical quality of the groundwater underlying the NTS. They classified groundwater on the NTS as belonging to one of three broad categories: (1) a sodium and potassium bicarbonate type; (2) a calcium and magnesium bicarbonate type; and (3) a type which consisted of mixtures of the first two, in varying proportions. The first groundwater type was found in the tuff aquifers and aquitards. The second type was found in Paleozoic carbonate aquifers as well as in the valley-fill aquifers, which were composed primarily of carbonate rock detritus. Mixed waters were thought to have formed in one of three ways: (1) by movement of water from tuffaceous rocks into carbonate rocks (or carbonate alluvium); (2) by movement of water from carbonates into tuffs; or (3) through mixing of the first two groundwater types. Chapman and Lyles (1993) examined groundwater chemical analysis results from a total of 81 wells obtained over the period from 1957 to 1990 . As in previous investigations, they determined the existence of three basic hydrochemical facies represented by the samples.

\section{POSSIBLE SOURCES FOR CONTAMINATION OF NTS WATER-SUPPLY WELLS}

\section{Underground Nuclear Tests}

Underground nuclear tests at the NTS have been conducted in either vertically drilled shafts or in tunnels. The five areas in which nuclear testing has been conducted on the NTS are identified in Figure 4 (denoted by shading of 1-km-radius circles around locations of underground tests). These areas are located in Yucca Flat, Frenchman Flat, Rainier Mesa, Pahute Mesa, and Shoshone Mountain, and are considered the source areas for radionuclides found within the groundwater. The 


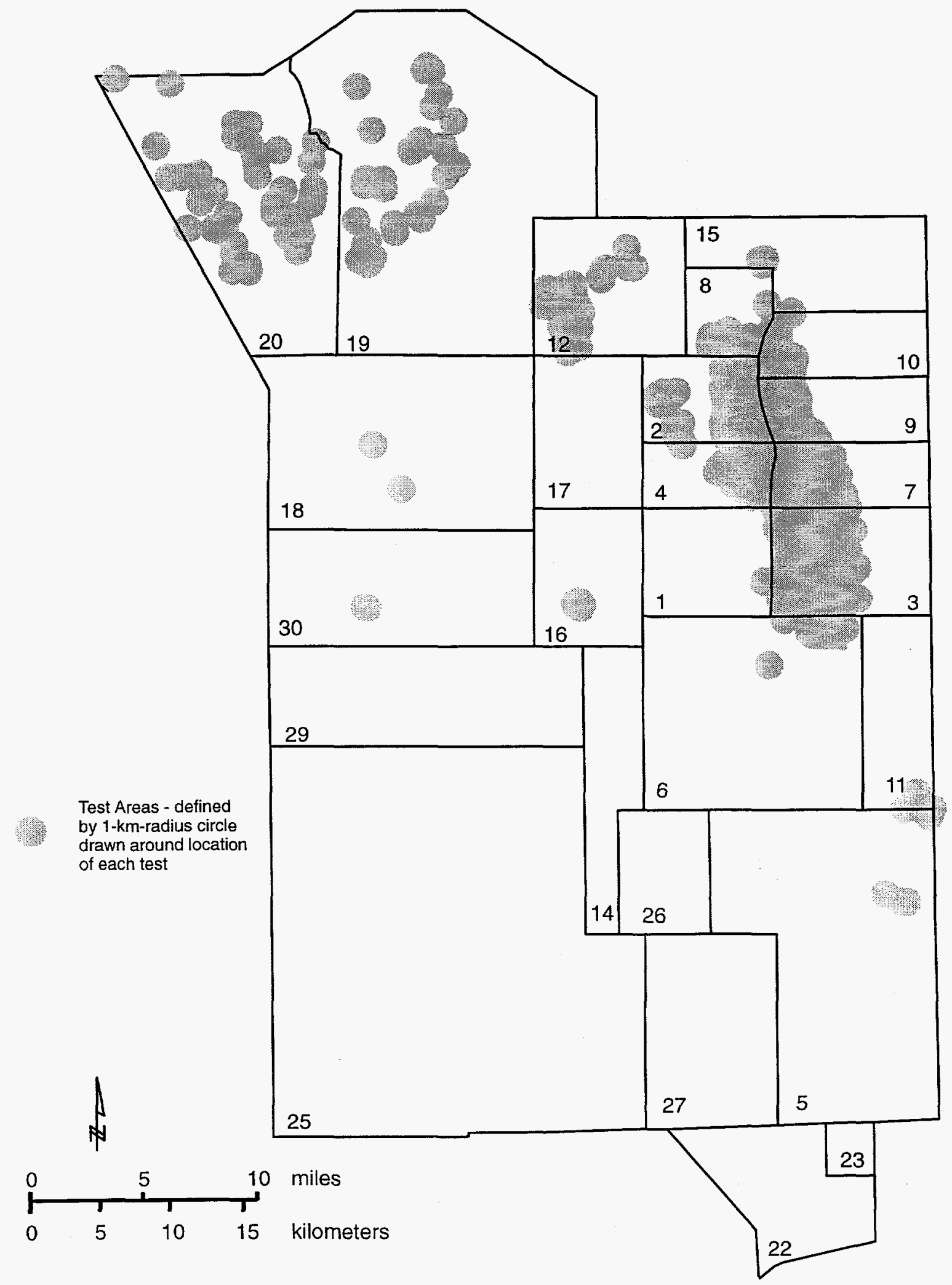

Figure 4. Underground nuclear testing locations at the Nevada Test Site. 
majority of underground testing has been conducted in unsaturated alluvium and Tertiary units. However, several nuclear tests were conducted within pre-Cenozoic units and at or below the water table. Approximately 160 nuclear tests were detonated near (within $25 \mathrm{~m}$ ) or below the water table.

\section{Existing Wells at the NTS}

Existing wells at the NTS, other than water-supply wells, can be grouped into five categories: emplacement (either expended or unexpended), satellite/instrument, postshot, exploration, and other.

\section{Emplacement Holes}

Emplacement holes at the NTS range from a few centimeters to more than two meters in diameter. These holes were drilled to provide access to the underground for the nuclear test device. Depending on the yield of the device to be contained, these holes range in depth from tens to hundreds of meters. Generally, these emplacement holes extend only slightly below the depth of burial for the device, however, if the depth of burial was to be near the water table, these holes may have been drilled until the water table was penetrated and then stemmed (back-filled) to above the water table prior to emplacement of the device. Following emplacement of the test device, these holes were stemmed with containment material to near the surface.

\section{Satellite and Instrument Holes}

Satellite holes at the NTS were constructed prior to drilling an emplacement hole for lithologic investigations. The primary purpose of these holes was to determine the lithologic character of the units intended to contain the proposed detonation, and to obtain geophysical logs which could not be conducted in the larger-diameter emplacement holes.

Prior to detonation of the underground test, instrument holes were drilled, or if suitable, satellite holes were used as instrument holes, to obtain seismic data from the test. Sensors were placed at the desired depths and the holes were then stemmed to the surface. As a general rule, satellite and instrument holes were located relatively close to their associated emplacement hole. Prior to detonation of the underground test, all holes within a distance of approximately one depth of burial for the device were plugged to prevent loss of containment during the test. As a result, almost all satellite and instrument holes at the NTS associated with expended emplacement holes are stemmed to the surface.

\section{Postshot Holes}

Postshot holes were holes drilled following detonation of an underground test to recover samples from the material in the cavity produced as a result of the test. These holes were also used to obtain gas samples from the chimney produced by the detonation. These samples were used to evaluate the test. Following completion of sampling, postshot holes were either plugged and abandoned, or an abandonment valve was installed on top of the surface casing and shut in, or a valve was placed on the gas sampling tubing which is cemented within the hole.

\section{Exploration}

Exploration holes at the NTS have been, and are currently, drilled for a variety of reasons. Early exploration holes were used to evaluate areas for proposed underground nuclear testing and to 
investigate the hydrology of the NTS. The Environmental Restoration (ER) Program, operated by the U.S. Department of Energy/Nevada Operations Office (DOE/NV), is currently constructing holes at the NTS to further investigate the hydrology of the NTS and to evaluate contaminate transport in the saturated and vadose zones.

\section{Other Boreholes}

Many holes exist at the NTS which were constructed for various purposes other than those listed above. Most of these holes are shallow (less than $500 \mathrm{~m}$ ) and do not extend to the water table.

\section{NTS WATER-SUPPLY WELLS}

In the following sections of this report, well construction and completion, static water levels, lithologic and hydrologic characteristics of aquifers penetrated, and general water quality of water-supply wells at the NTS are described. This information is summarized in Table 3 . Well construction and completion information was obtained from Raytheon Services Nevada (RSN) hole-histories and various United States Geological Survey (USGS) reports. Static water levels, lithologic and hydrologic characteristics of aquifers penetrated were obtained from various USGS, Lawerence Livermore National Laboratory (LLNL), Los Alamos National Laboratory (LANL), NTS Site Maintenance Department, and Desert Research Institute (DRI) records and reports. Water quality data (Table 4) represent an average of historical water quality sample results.

TABLE 3. SUMMARY OF CONSTRUCTION, LITHOLOGIC, AND HYDROLOGIC CHARACTERISTICS OF NTS WATER-SUPPLY WELLS.

\begin{tabular}{lccccrcc}
\hline \hline \multicolumn{1}{c}{ Well } & $\begin{array}{c}\text { Surface } \\
\text { Elevation }\end{array}$ & $\begin{array}{c}\text { Total } \\
\text { Depth }\end{array}$ & $\begin{array}{c}\text { Septh to } \\
\text { Static Water } \\
\text { Level }\end{array}$ & $\begin{array}{c}\text { Pumping } \\
\text { Rate } \\
\mathrm{m}^{3} / \text { day }\end{array}$ & $\begin{array}{c}\text { Specific } \\
\text { Capacity } \\
\mathrm{m}^{3} / \text { day/m }\end{array}$ & $\begin{array}{c}\text { Transmis- } \\
\text { sivity } \\
\mathrm{m}^{2} / \text { day }\end{array}$ & $\begin{array}{c}\text { Aquifer } \\
\text { Type }\end{array}$ \\
\hline Water Well 5C & 939.1 & 365.8 & 210.6 & 1650 & 23 & 31 & Alluvium \\
Water Well 5B & 942.4 & 274.6 & 208.5 & 1300 & 70 & 137 & Alluvium \\
Water Well UE-5c & 980.2 & 817.5 & 245.1 & 1908 & 30 & N/A & Alluvium \\
Water Well Army\#1 & 961.3 & 595.3 & 239.9 & 2450 & 90 & 1068 & Carbonate \\
Water Well UE-16d & 1427.7 & 914.4 & 230 & 1057 & 217 & N/A & Carbonate \\
Water Well J-12 & 954 & 347.2 & 225.9 & 2080 & 1700 & 1242 & Volcanics \\
Water Well J-13 & 954 & 1066.2 & 282.8 & 3640 & 540 & 845 & Volcanics \\
Water Well 8 & 1735.7 & 1673.3 & 328.6 & 3160 & 1200 & 2298 & Volcanics \\
Water Well 4 & 1098.2 & 273.7 & 286.8 & 3543 & 140 & N/A & Volcanics \\
Water Well 4A & 1099 & 462.1 & 254.5 & 3816 & 321 & N/A & Volcanics \\
Water Well C & 1195.2 & 518.5 & 469.7 & 1581 & 10373 & 11180 & Carbonate \\
Water Well C-1 & 1195.1 & 502.9 & 470 & 1581 & 519 & 75 & Carbonate \\
Water Well 2 & 1362.5 & 1043 & 626.4 & 927 & 10.8 & N/A & Carbonate \\
Water Well U-20 & 1971.4 & 996.1 & 620.3 & 1526 & 7.4 & N/A & Volcanics \\
Water Well UE-19c & 2143.7 & 2587.5 & 714.7 & 1962 & 73 & 149 & Volcanics \\
\hline \hline
\end{tabular}


TABLE 4. MAJOR ION CHEMISTRY FROM NTS WATER-SUPPLY WELLS (mg/l).

\begin{tabular}{lccccccc}
\hline \multicolumn{1}{c}{ Well Name } & $\begin{array}{c}\text { Sodium } \\
(\mathrm{Na})\end{array}$ & $\begin{array}{c}\text { Potassium } \\
(\mathrm{K})\end{array}$ & $\begin{array}{c}\text { Calcium } \\
(\mathrm{Ca})\end{array}$ & $\begin{array}{c}\text { Magnesium } \\
(\mathrm{Mg})\end{array}$ & $\begin{array}{c}\text { Chlorine } \\
(\mathrm{Cl})\end{array}$ & $\begin{array}{c}\text { Bicarbonate }+ \\
\text { Carbonate } \\
\left(\mathrm{HCO}_{3}+\mathrm{CO}_{3}\right)\end{array}$ & $\begin{array}{c}\text { Sulfate } \\
\left(\mathrm{SO}_{4}\right)\end{array}$ \\
\hline Water Well 5C & 129 & 6 & 2.4 & 0.6 & 9.1 & 271 & 26 \\
Water Well 5B & 96.6 & 10.6 & 7.7 & 1.7 & 23.2 & 166 & 58 \\
Water Well UE-5c & 83.5 & 6.3 & 9.1 & 2.1 & 12.1 & 163 & 44 \\
Water Well Army \#1 & 38.1 & 5.4 & 44 & 20.9 & 16.1 & 257 & 53 \\
Water Well UE-16d & 33.1 & 6.8 & 70.8 & 25.2 & 11.8 & 293 & 62 \\
Water Well J-12 & 41.2 & 5 & 14 & 1.8 & 7.6 & 119 & 22 \\
Water Well J-13 & 45.6 & 5.8 & 13.9 & 2.1 & 7.7 & 126 & 23 \\
Water Well 8 & 29.6 & 3.4 & 8.5 & 1.1 & 7.6 & 78 & 15 \\
Water Well \#4 & 48.5 & 5.3 & 25.6 & 8.2 & 11.6 & 159 & 41 \\
Water Well \#4A & N/A & N/A & N/A & N/A & N/A & N/A & N/A \\
Water Well C & 127.1 & 14 & 71.1 & 27 & 32.6 & 566 & 67 \\
Water Well C-1 & 124.2 & 3.9 & 59.1 & 28.5 & 33.9 & 550 & 65 \\
Water Well 2 & 28.2 & 6.7 & 32.2 & 15 & 7.2 & 210 & 23 \\
Water Well U-20 & 57.8 & 1.8 & 5.9 & 0.4 & 11.7 & 111 & 30 \\
Water Well UE-19c & 53.6 & 0.5 & 3.7 & 0.2 & 3.5 & 134 & 5 \\
\hline \hline
\end{tabular}

Possible sources for contamination of the water-supply wells were also evaluated. Existing wells and underground nuclear tests conducted near (within 25 meters) or below the water table within $2 \mathrm{~km}$ of a water-supply well were located and their hydrogeologic relationship to the water-supply well determined. Lithologic symbols and stratigraphic nomenclature used in well construction diagrams and geologic cross sections are given in Appendix A and B, respectively.

Water-supply wells at the NTS are sampled on an annual basis by the DOE/NV Long-term Hydrologic Monitoring Program. Samples from water-supply wells, as well as other wells at the NTS, are analyzed for tritium content and by gamma spectrometry. Sample analysis results are published annually in the DOE/NV Annual Site Environmental Report. During the last two years for which records are available (1993 and 1994), all water-supply wells were sampled at least once, with the exception of Water Well UE-19c. Analysis results did not indicate the presence of elevated tritium concentrations within any of the water-supply wells sampled.

In addition to the radiological analysis conducted by the Long-term Hydrologic Monitoring Program, water-supply wells at the NTS are sampled regularly by both Bechtel Nevada and the State 
of Nevada and analyzed for Safe Drinking Water Act constituents, with the results published in the Annual Site Environmental Report. Although these are not potable water-supply wells, Water Wells U-20 and UE-19c are also sampled for Safe Drinking Water Act constituents.

\section{Water Well 5C}

\section{Location}

Water Well 5C is located in central Frenchman Flat (Figure 5) within the Ash Meadows subbasin groundwater flow system. Elevation at the well site is $939.1 \mathrm{~m}$ above mean sea level (MSL). Water Well 5C is located south (downgradient) of underground nuclear tests conducted in Frenchman and Yucca flats. Potentiometric data (Winograd and Thordarson, 1975) indicate a virtually flat groundwater gradient in the area of Water Well 5C. The apparent general direction of groundwater flow in the area of Water Well 5C is from northwest to southeast (Figure 3).

\section{Construction/Completion}

Water Well 5C (Figure 6) was drilled in 1954 with rotary tools using aqua-gel as drilling fluid. A 34-cm hole was drilled to $6.1 \mathrm{~m}$, where 32.4-cm casing was run to $6.1 \mathrm{~m}$ and cemented to the surface. A 31.1-cm bit was used to drill the hole to a total depth of $365.8 \mathrm{~m}$. Records are scarce, but it is assumed that $27.3-\mathrm{cm}$-diameter casing was installed to a depth of $361.8 \mathrm{~m}$ and hung from the surface with no cement used. The $27.3-\mathrm{cm}$ casing was perforated from 270.4 to $361.8 \mathrm{~m}$.

\section{Hydrogeology}

Water Well $5 \mathrm{C}$ is completed entirely within alluvium (Figure 6). Static water level in the well is reported at $210.6 \mathrm{~m}$ below land surface. Specific capacity for Water Well 5C is reported as approximately $23 \mathrm{~m}^{3} /$ day $/ \mathrm{m}$ of drawdown at a production rate of approximately $1650 \mathrm{~m}^{3} /$ day (Claassen, 1973). Mean transmissivity for Water Well 5C is estimated as $31 \mathrm{~m}^{2} /$ day (Winograd and Thordarson, 1975).

Water quality data (Chapman and Lyles, 1993) from the well indicate a $\mathrm{Na}+\mathrm{K}+\mathrm{HCO}_{3}$ water type (Figure 7). This water type is typical of volcanic aquifers or alluvium aquifers composed primarily of volcanic rock fragments. Records also indicate the well was treated with acid in 1966, which may account for the low $\mathrm{Ca}$ and $\mathrm{Mg}$ content of the water from the well.

Proximity to Underground Nuclear Tests and Existing Wells

No underground tests were conducted near (within $25 \mathrm{~m}$ ) or below the water table located within $2 \mathrm{~km}$ of Water Well 5C. Two existing wells, Water Well 5B (active NTS water-supply well) and Water Well 5A (abandoned NTS water-supply well), are located within $2 \mathrm{~km}$ of Water Well 5C. Water Well 5B is located approximately $1 \mathrm{~km}$ northwest of Water Well 5C; Water Well 5A is located approximately $1 \mathrm{~km}$ southeast of Water Well 5C (Figure 8).

\section{Water Well 5B}

\section{Location}

Water Well 5B (Figure 5) is located in central Frenchman Flat within the Ash Meadows subbasin groundwater flow system. Elevation at the well site is $942.4 \mathrm{~m}$ MSL. Water Well 5B is 
1 Water Well 5C

2 Water Well 5B

3 Water Well UE-5c

4 Water Well Army \# 1

5 Water Well UE-16d

Water Well J-12

7 Water Well J-13

8 Water Well 8

9 Water Well 4

Water Well 4A

Water Well $C$

12 Water Well C-1

13 Water Well 2

14 Water Well U-20

15 Water Well UE-19c

Test Areas - defined by $1-\mathrm{km}$-radius circle drawn around location of each test

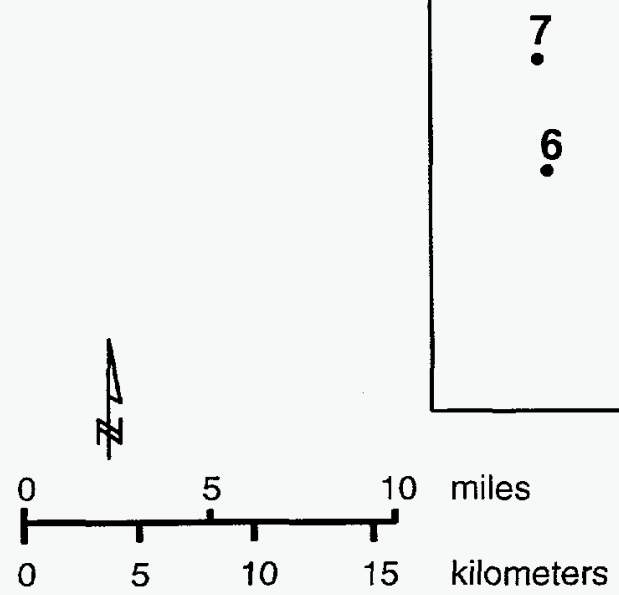

Figure 5. Location of NTS water-supply wells. 


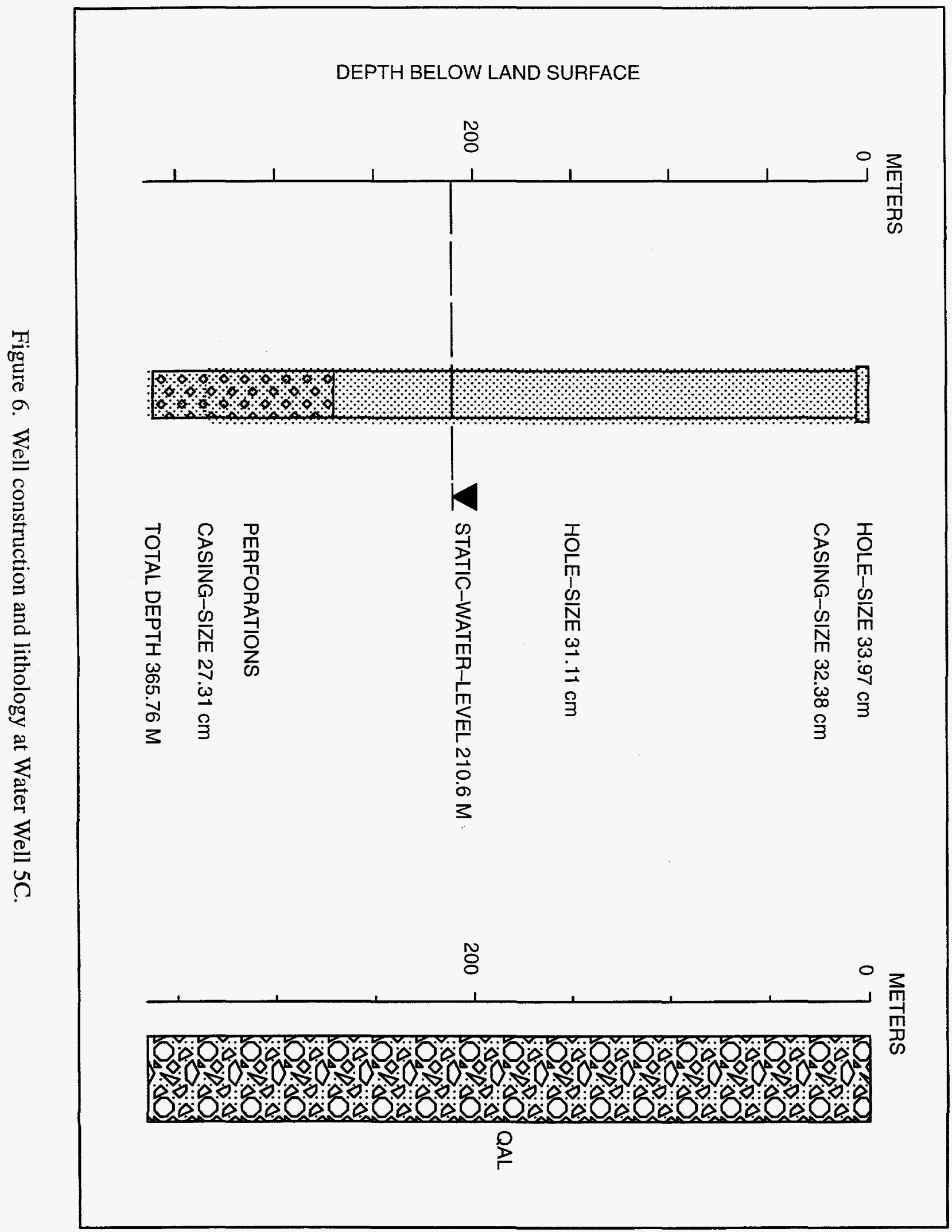




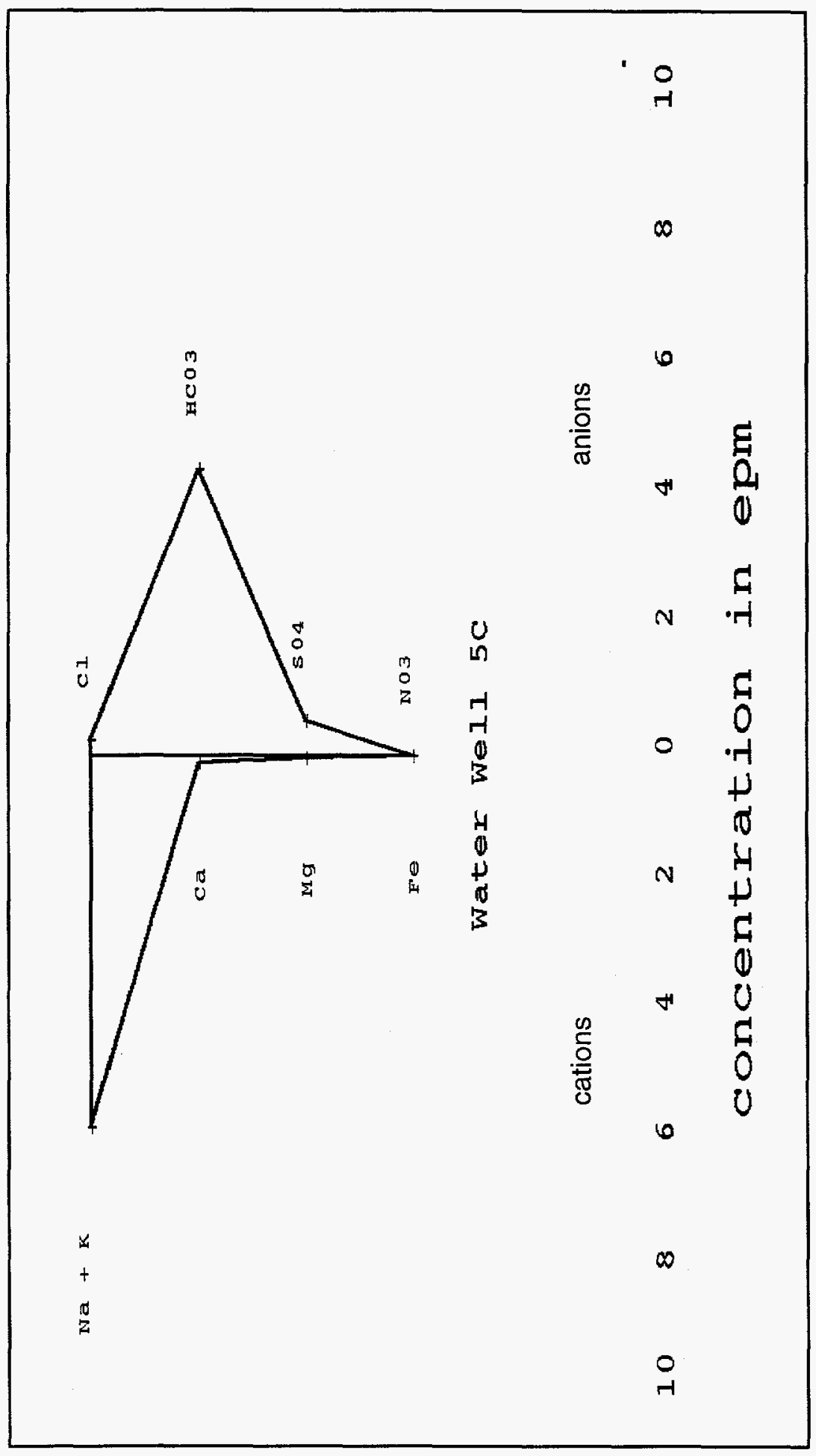

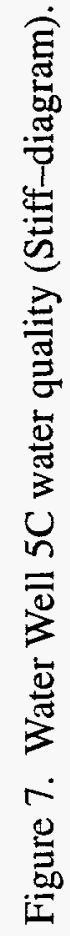




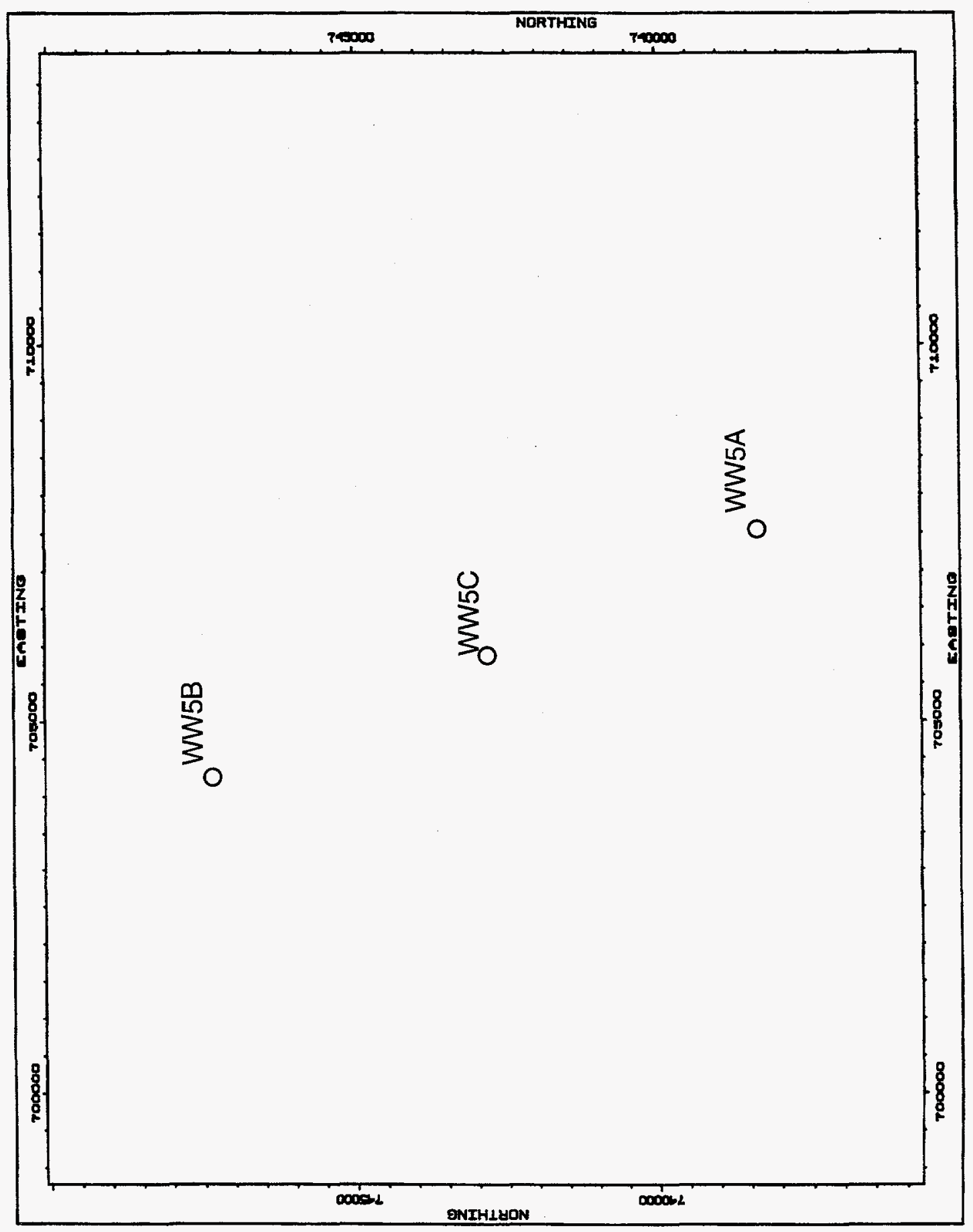

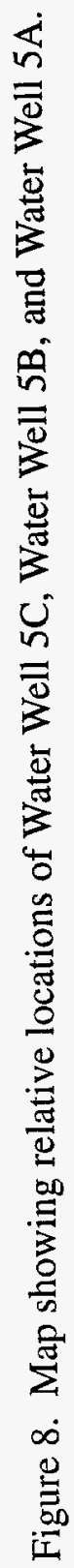


located south (downgradient) of underground nuclear tests conducted in Frenchman and Yucca flats. Potentiometric data (Winograd and Thordarson, 1975) indicate a virtually flat groundwater gradient in the area of Water Well 5B. The apparent general direction of groundwater flow in the area of Water Well 5B is from northwest to southeast (Figure 3).

\section{Construction/Completion}

Water Well 5B (Figure 9) was drilled in 1951 with cable tools. A 38.1-cm-diameter hole was drilled from the surface to $140.2 \mathrm{~m}$ and cased with 32.4-cm-diameter casing. It is not recorded but the annular space between this casing and the borehole was probably either cemented to surface or tack cemented at the bottom and the surface. A $30.5-\mathrm{cm}$-diameter hole was drilled from $140.2 \mathrm{~m}$ to total depth at $274.6 \mathrm{~m}$ and a liner casing was installed in the borehole from 134.1 to $274.3 \mathrm{~m}$. It is unknown if cement was used in the installation of the liner, but most likely cement was not used. The bottom section of the liner is slotted from 213.4 to $274.3 \mathrm{~m}$.

\section{Hydrogeology}

Water Well 5B (Figure 9) is completed entirely within alluvium. Static water level in the well is reported at $208.5 \mathrm{~m}$ below land surface. Specific capacity for Water Well 5C is reported as approximately $70 \mathrm{~m}^{3} / \mathrm{day} / \mathrm{m}$ of drawdown at a production rate of approximately $1300 \mathrm{~m}^{3} / \mathrm{day}$ (Claassen, 1973). Mean transmissivity for Water Well 5B is estimated as $137 \mathrm{~m}^{2} /$ day (Winograd and Thordarson, 1975).

Water quality data (Chapman and Lyles, 1993) from the well indicate a $\mathrm{Na}+\mathrm{K}+\mathrm{HCO}_{3}$ water type but with significant $\mathrm{Ca}$ and $\mathrm{Mg}$ content. (Figure 10). This mixed water type is typical of alluvium aquifers composed of carbonate and volcanic rock fragments.

\section{Proximity to Underground Nuclear Tests and Existing Wells}

No underground tests were conducted near (within $25 \mathrm{~m}$ ) or below the water table located within $2 \mathrm{~km}$ of Water Well 5B. One existing well, Water Well 5C (an active NTS water-supply well) is located within $2 \mathrm{~km}$ of Water Well 5B. Water Well 5B is located approximately $1 \mathrm{~km}$ southeast of Water Well 5C (Figure 8).

\section{Water Well UE-5c}

Location

Water Well UE-5c is located in central Frenchman Flat within the Ash Meadows subbasin groundwater flow system (Figure 5). Elevation at the well site is $980.2 \mathrm{~m} \mathrm{MSL}$. Water Well UE-5c is located south (downgradient) of underground nuclear tests conducted in Frenchman and Yucca flats. Potentiometric data (Winograd and Thordarson, 1975) indicate a virtually flat groundwater gradient in the area of Water Well UE-5c. The apparent general direction of groundwater flow in the area of Water Well UE-5c is from northwest to southeast (Figure 3). Water Well UE-5c is located perpendicular to apparent flow lines, or upgradient from underground tests conducted in Frenchman Flat.

\section{Construction/Completion}

Water Well UE-5c (Figure 11) was drilled in 1964 with rotary tools. A 44.45-cm-diameter hole was drilled to $512.7 \mathrm{~m}$ where a string of 34-cm-diameter casing was installed and the annular space 

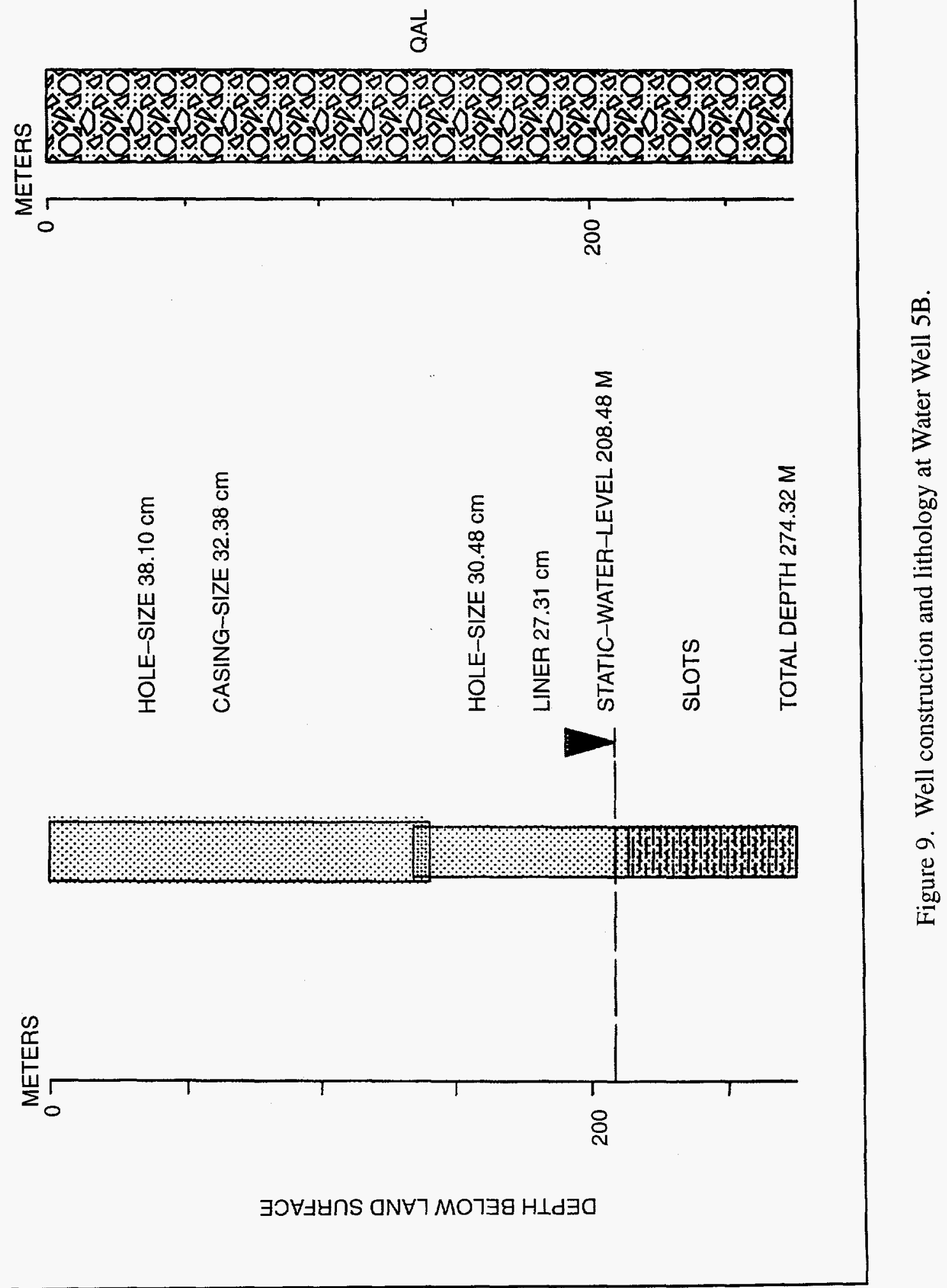


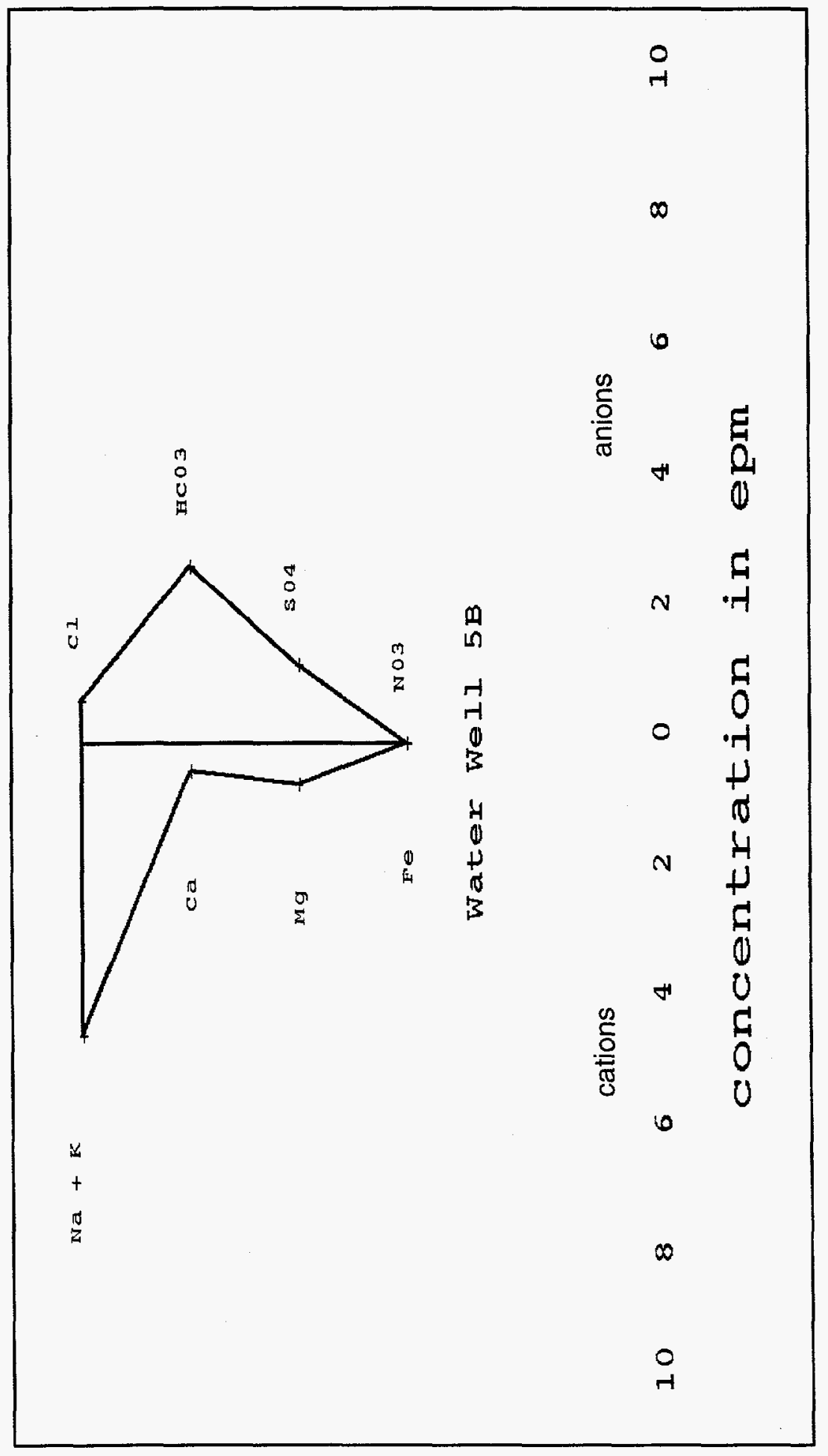

完 


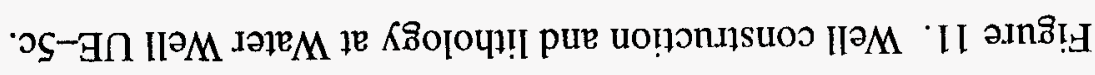

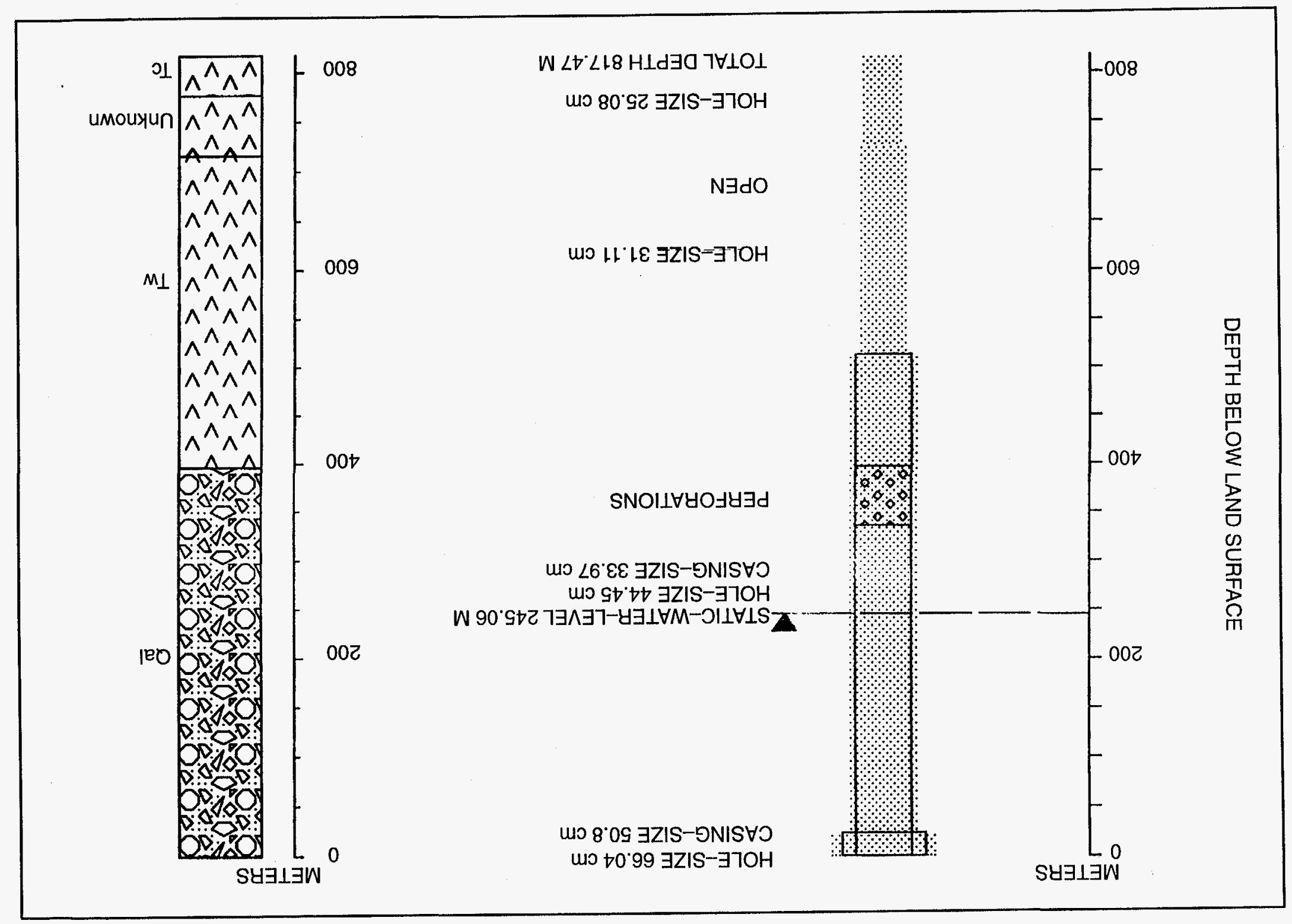


between the casing and the borehole cemented to the surface. A 31.1-cm-diameter hole was then drilled from $512.7 \mathrm{~m}$ to $726.9 \mathrm{~m}$ and a 25.1 -cm-diameter hole drilled from $726.9 \mathrm{~m}$ to total depth at $817.5 \mathrm{~m}$. Water Well UE-5c was drilled using an air and Davis mix, drilling mud, and aerated mud. Following completion of the well, the 34-cm-diameter casing was gun perforated from 335.3 to $396.2 \mathrm{~m}$.

\section{Hydrogeology}

The 34-cm-diameter casing in Water Well UE-5c extends to the base of alluvium which overlies units of the Wahmonie and Salyer tuffs (Figure 11). Static water level in the well is reported at $245.1 \mathrm{~m}$ below land surface. NTS Site Maintenance Department records (unpublished) indicate a specific capacity of $30.1 \mathrm{~m}^{3} /$ day $/ \mathrm{m}$ of drawdown at a discharge rate of $2450 \mathrm{~m} /$ day. Water quality data from the well indicate a $\mathrm{Na}+\mathrm{K}+\mathrm{HCO}_{3}$ water type typical of volcanic and tuffaceous-rich alluvium aquifers (Figure 12). Completion of the well and water quality data indicate the major water production in the well is most likely from the alluvium aquifer with minor contribution from the tuff units (Wahmonie Tuff and Salyer Tuff) penetrated by the well.

\section{Proximity to Underground Nuclear Tests and Existing Wells}

One underground test (U-5e) was conducted near (within $25 \mathrm{~m}$ ) or below the water table, and three additional existing wells, RNM \#1, RNM \#2 and RNM \#2S, are located within $2 \mathrm{~km}$ of Water Well UE-5c (Figure 13). The three RNM (Radionuclide Migration) wells were drilled to investigate migration of radionuclides from the test conducted just below the water table at U-5e. U-5e and the three RNM wells are located approximately $1.9 \mathrm{~km}$ southeast (downgradient) of Water Well UE-5c.

\section{Water Well Army \#1}

\section{Location}

Water Well Army \#1 is located in Mercury Valley within the Ash Meadows subbasin groundwater flow system (Figure 5). Elevation at the well site is $961.3 \mathrm{~m} \mathrm{MSL}$. Water Well Army \#1 is located south (downgradient) of underground nucleartests conducted in Frenchman and Yucca flats. Potentiometric data (Winograd and Thordarson, 1975) indicate the general direction of groundwater flow in the area of Water Well Army \#1 to be from northeast to southwest (Figure 3).

\section{Construction/Completion}

Construction of Water Well Army \#1 (Figure 14) began in 1958 using cable tools to drill an initial 31.1-cm-diameter hole to a depth of $189 \mathrm{~m}$. In 1962, a 44.4-cm-diameter rotary bit was used to open the $31.1-\mathrm{cm}$-diameter hole a depth of $188.4 \mathrm{~m}$. A string of 34-cm-diameter casing was then set to $185.3 \mathrm{~m}$ and cemented with $7.1 \mathrm{~m}^{3}$ of cement. A 19.4-cm-diameter hole was then drilled from $188.4 \mathrm{~m}$ to $396.2 \mathrm{~m}$ using air-foam to circulate the cutting from the hole. The $19.4-\mathrm{cm}$-diameter hole was then opened to $31.1-\mathrm{cm}$-diameter and $27.3-\mathrm{cm}$-diameter casing was placed in the hole and tack cemented over the lower portion with $2.8 \mathrm{~m}^{3}$ of cement. A $25.1-\mathrm{cm}$-diameter hole was drilled from $396.2 \mathrm{~m}$ to $417.6 \mathrm{~m}$ and a $17.8-\mathrm{cm}$-diameter liner was run from $364.8 \mathrm{~m}$ to $414.5 \mathrm{~m}$ and cemented in place with $2.5 \mathrm{~m}^{3}$ of cement. A $22.9-\mathrm{cm}$-diameter bit was used to drill from $417.6 \mathrm{~m}$ to $513.3 \mathrm{~m}$. A 17.1-cm-diameter bit was used to drill from $513.3 \mathrm{~m}$ to $539.8 \mathrm{~m}$ and a 15.6 bit was used to drill to total depth at $595.3 \mathrm{~m}$. Following construction of the borehole, the $27.3-\mathrm{cm}$-diameter casing was perforated from 274.3 to $320 \mathrm{~m}$ and from 274 to $274.3 \mathrm{~m}$. 


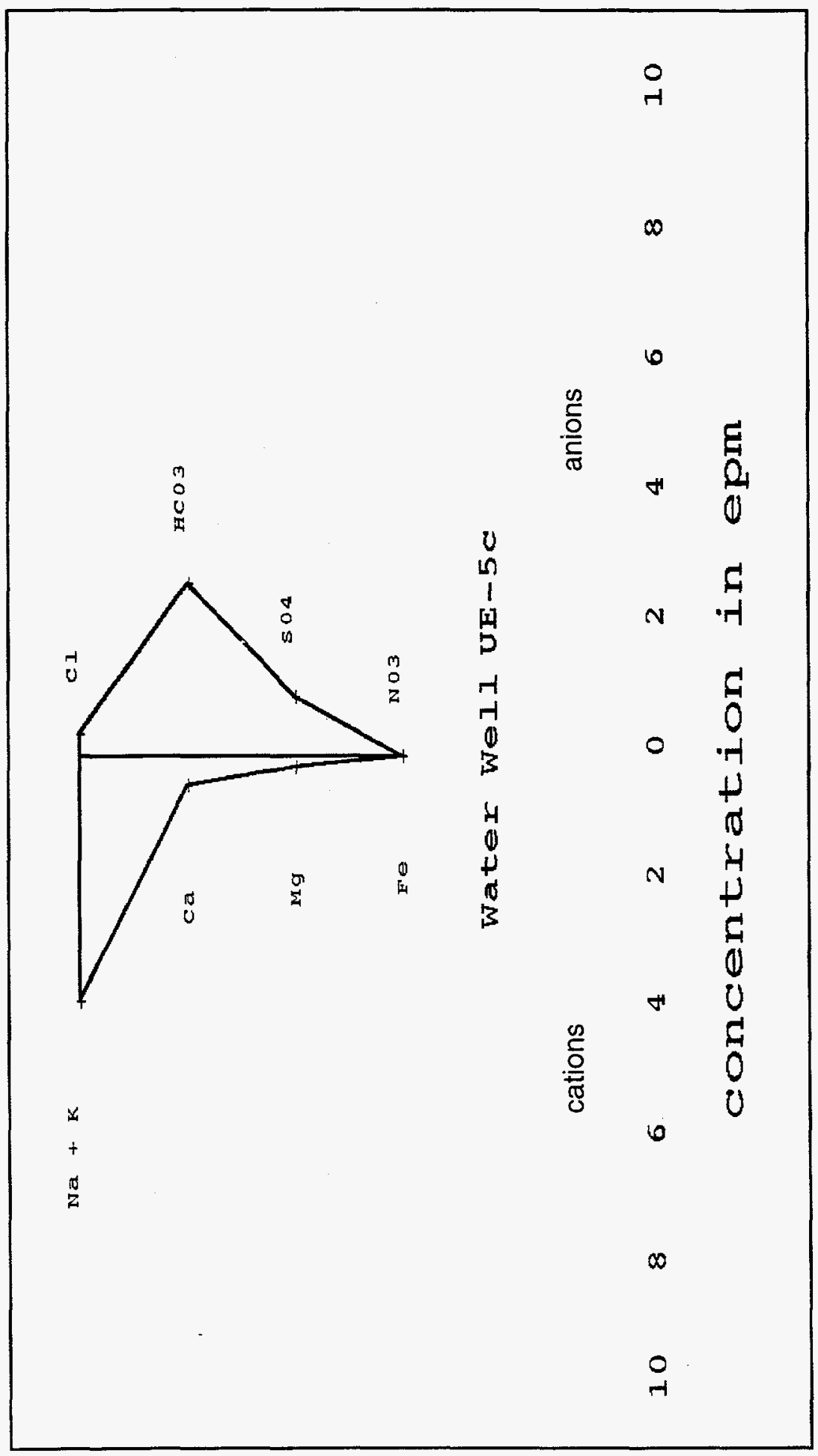




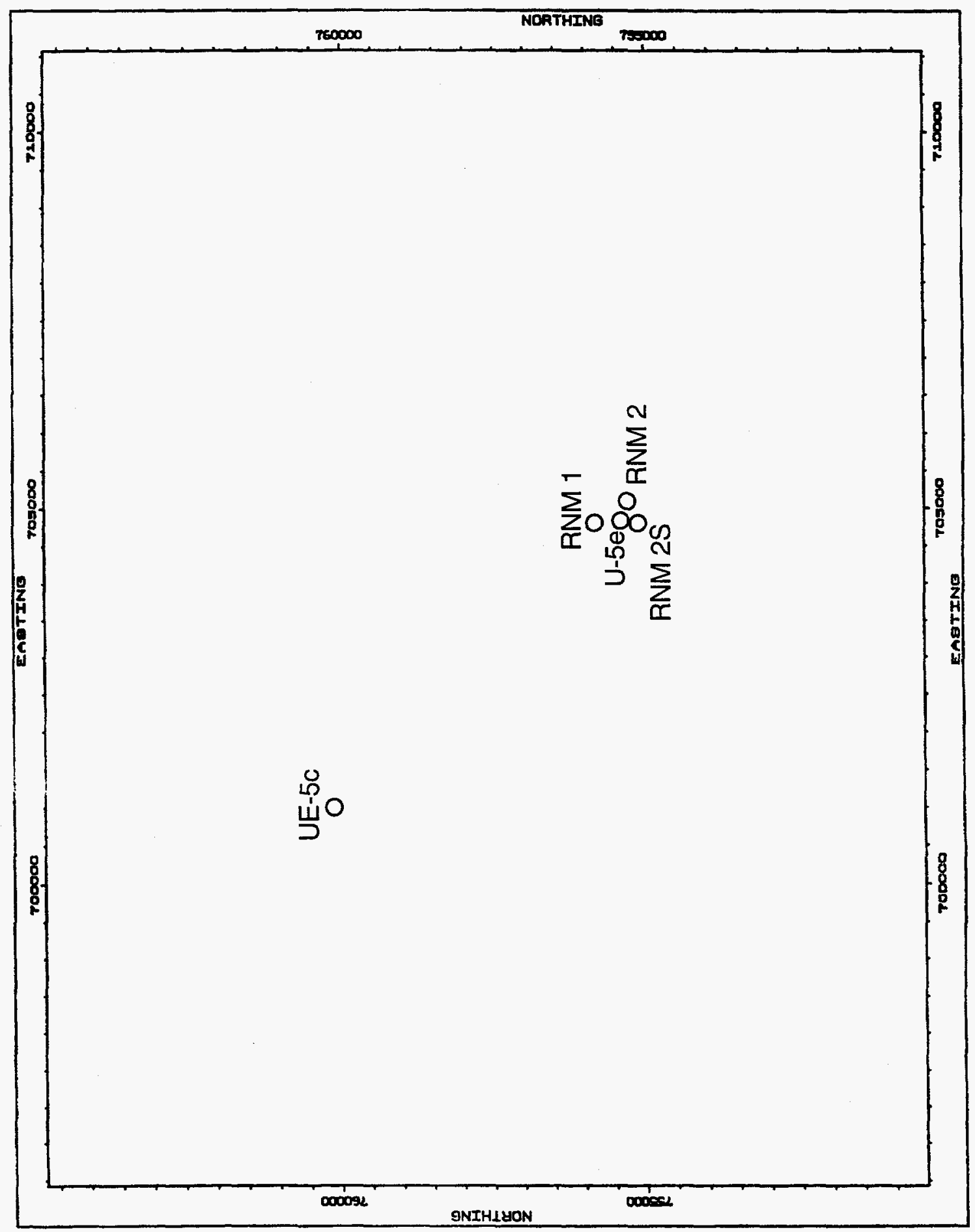

年 


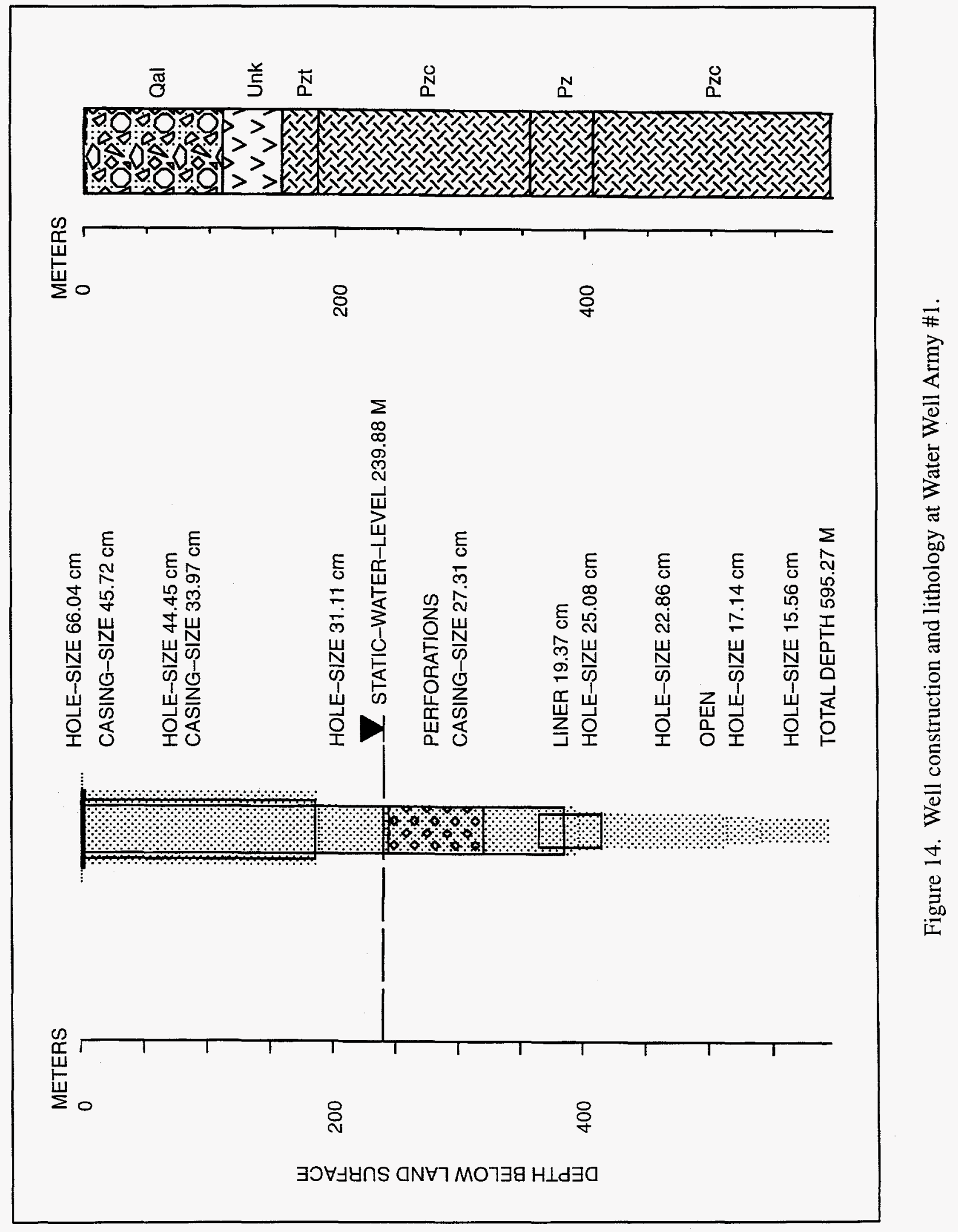




\section{Hydrogeology}

Static water level in the well is reported at $239.9 \mathrm{~m}$ below land surface. Production tests conducted at Water Well Army \#1 indicated a specific capacity of approximately $90 \mathrm{~m} 3 / \mathrm{day} / \mathrm{m}$ of drawdown with a drawdown of $8 \mathrm{~m}$ at a discharge rate of $2450 \mathrm{~m}^{3} /$ day (Claassen, 1973). Mean transmissivity of Water Well Army \#1 is estimated as $1068 \mathrm{~m}^{2} /$ day (Winograd and Thordarson, 1975).

The saturated interval penetrated by Water Well Army \#1 consists entirely of dolomites and limestones with some interbedded shales of the lower carbonate aquifer (Figure 14). Water quality data (Chapman and Lyles, 1993) from the well indicate a $\mathrm{Ca}+\mathrm{Mg}+\mathrm{HCO}_{3}$ water type typical of carbonate aquifers (Figure 15).

Proximity to Underground Nuclear Tests and Existing Wells

No underground tests or existing wells are located within $2 \mathrm{~km}$ of Water Well Army \#1.

\section{Water Well UE-16d}

\section{Location}

Water Well UE-16d is located west of Yucca Flat on the western flank of Syncline Ridge (Figure 5). Land surface elevation at the well site is $1427.7 \mathrm{~m}$ MSL. Water Well UE-16d is located on the eastern edge of the Alkali Flat-Furnace Creek Ranch subbasin groundwater flow system. Potentiometric data (Winograd and Thordarson, 1975) indicate the general direction of groundwater flow in the area of Water Well UE-16d to be from northwest to southeast (Figure 3).

\section{Construction/Completion}

Water Well UE-16d (Figure 16) was drilled in 1977 to a total depth of $914.4 \mathrm{~m}$. During construction, 17.8-cm-diameter casing was set in the well to a depth of $645.9 \mathrm{~m}$. The annular space between this casing and the wellbore was cemented to from 574.5 to $645.9 \mathrm{~m}$. Below this casing, a 15.9-cm-diameter hole was drilled to total depth. Air foam was used to circulate cuttings from the hole from 253 to $742.5 \mathrm{~m}$; mud was used from $742.5 \mathrm{~m}$ to total depth.

\section{Hydrogeology}

Below the water table, Water Well UE-16d penetrates units of the upper carbonate aquifer (Tippipah Limestone) which are underlain by quartzites of the upper clastic aquitard (Eleana Formation, Unit J) (Figure 16). The 17.8-cm-diameter casing in the well was set and cemented within units of the upper clastic aquitard effectively isolating the upper carbonate interval from the well.

In 1981, a bridge plug was placed in the $17.8-\mathrm{cm}$-diameter casing at $615.7 \mathrm{~m}$, isolating the lower clastic aquitard from the upper portion of the well. The 17.8-cm-diameter casing was then perforated from 349 to $399.3 \mathrm{~m}$, opening the upper portion of the well to the upper carbonate interval. Fluid level in the well is currently reported at $230 \mathrm{~m}$ below land surface.

NTS Site Maintenance Department records (unpublished) indicate a specific capacity of 217 $\mathrm{m}^{3} /$ day $/ \mathrm{m}$ of drawdown at a discharge rate of $1057 \mathrm{~m}^{3} /$ day. Water quality data (Chapman and Lyles, 


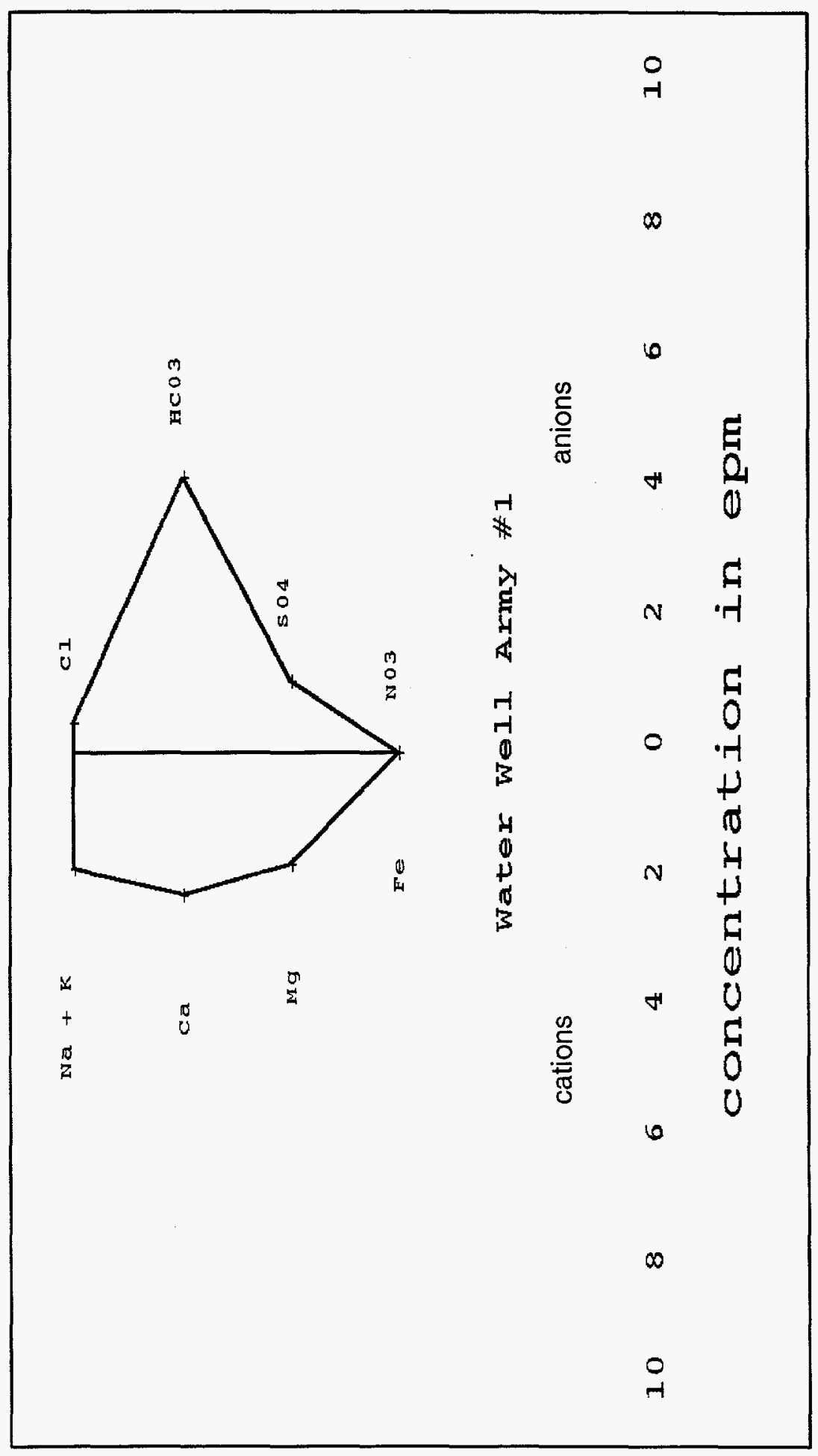

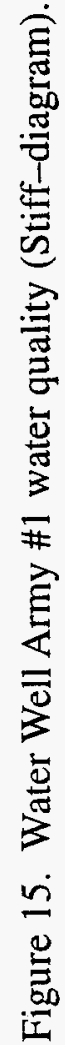




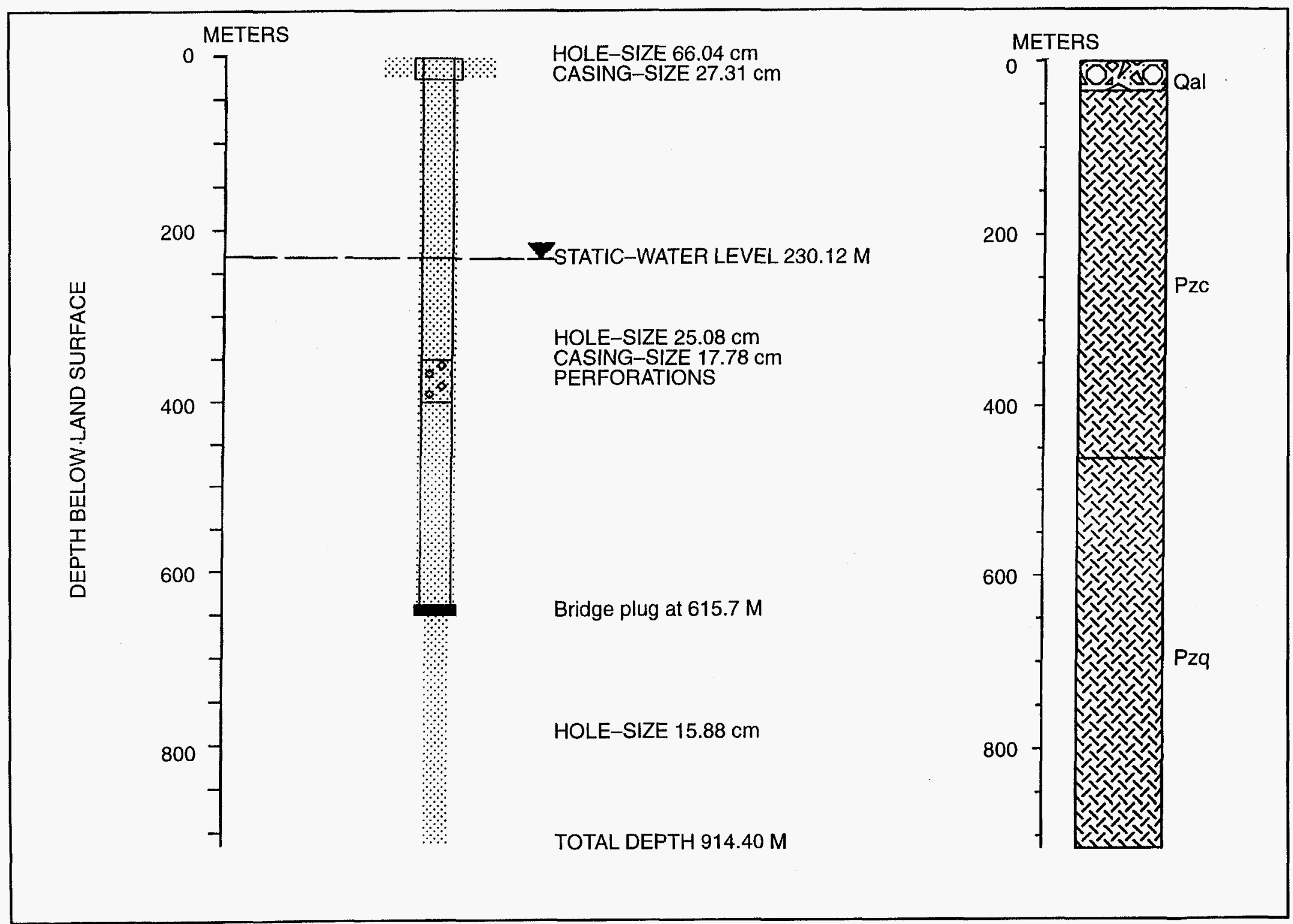

Figure 16. Well construction and lithology at Water Well UE-16d. 
1993) from Water Well UE-16d indicates a $\mathrm{Ca}+\mathrm{Mg}+\mathrm{HCO}_{3}$ water type typical of carbonate aquifers (Figure 17). Water production from Water Well UE-16d originates from the upper carbonate aquifer (Tippipah Limestone) which forms Syncline Ridge.

\section{Proximity to Underground Nuclear Tests and Existing Wells}

No underground tests were conducted near (within $25 \mathrm{~m}$ ) or below the water table located within $2 \mathrm{~km}$ of Water Well UE-16d. Four wells (UE-16c, UE-17a, UE-17b and UE-17d) are located within $2 \mathrm{~km}$ of Water Well UE-16d (Figure 18).

Wells UE-16c, UE-17b and UE-17d are relatively shallow (less than $125 \mathrm{~m}$ total depth) and do not penetrate the water table, penetrating only alluvium and units of the upper clastic aquitard (Eleana Formation). None of the three wells encounter units of the upper carbonate aquifer.

Well UE-17a was drilled to a total depth of $370 \mathrm{~m}$. Fluid level within the borehole is reported at $193.8 \mathrm{~m}$ below land surface. This fluid level is well below the contact between the upper carbonate aquifer and the upper clastic aquitard penetrated by the wellbore at a depth of $166.4 \mathrm{~m}$.

Because wells UE-16c, UE-17a, UE-17b and UE-17d are completed in the upper clastic aquitard, these wells do not present a hazard to Water Well UE-16d.

\section{Water Well J-12}

\section{Location}

Water Well J-12 is located in Jackass Flats in the southwestern portion of the NTS (Figure 5). Land surface elevation at the well site is $954 \mathrm{~m}$ MSL. Water Well J-12 is located in the Alkali Flat-Furnace Creek Ranch subbasin groundwater flow system. Potentiometric data (Winograd and Thordarson, 1975) indicate the general direction of groundwater flow in the area of Water Well J-12 to be from north to south (Figure 3).

\section{Construction/Completion}

The initial borehole at Water Well J-12 (Figure 19) was drilled in 1957 to a total depth of 270.4 $\mathrm{m}$. This original borehole was completed with $32.4-\mathrm{cm}$-diameter casing to total depth. It is not known whether cement was used in the installation of this casing; most likely cement was not used in placement of this casing. The casing was slotted from $241.7 \mathrm{~m}$ to $264.6 \mathrm{~m}$.

In 1968 , the well was deepened from $270.4 \mathrm{~m}$ to $347.2 \mathrm{~m}$ using a $29.8-\mathrm{cm}$-diameter bit. It is not known, but is assumed, rotary tools with conventional circulation of air and/or air-foam was used to construct this portion of the borehole. Casing was not placed in this portion of the well. The last reported total depth for Water Well J-12 was $310.6 \mathrm{~m}$

\section{Hydrogeology}

Static water level in Water Well J-12 is reported as $225.9 \mathrm{~m}$ below land surface. Following completion of the initial borehole, a production test was conducted at a pumping rate of $2080 \mathrm{~m}^{3} /$ day. This test resulted in a drawdown of $1.2 \mathrm{~m}$, yielding a specific capacity for the well of $1700 \mathrm{~m}^{3} / \mathrm{day} / \mathrm{m}$ of drawdown (Claassen, 1973). The latest production test conducted in the deepened borehole 


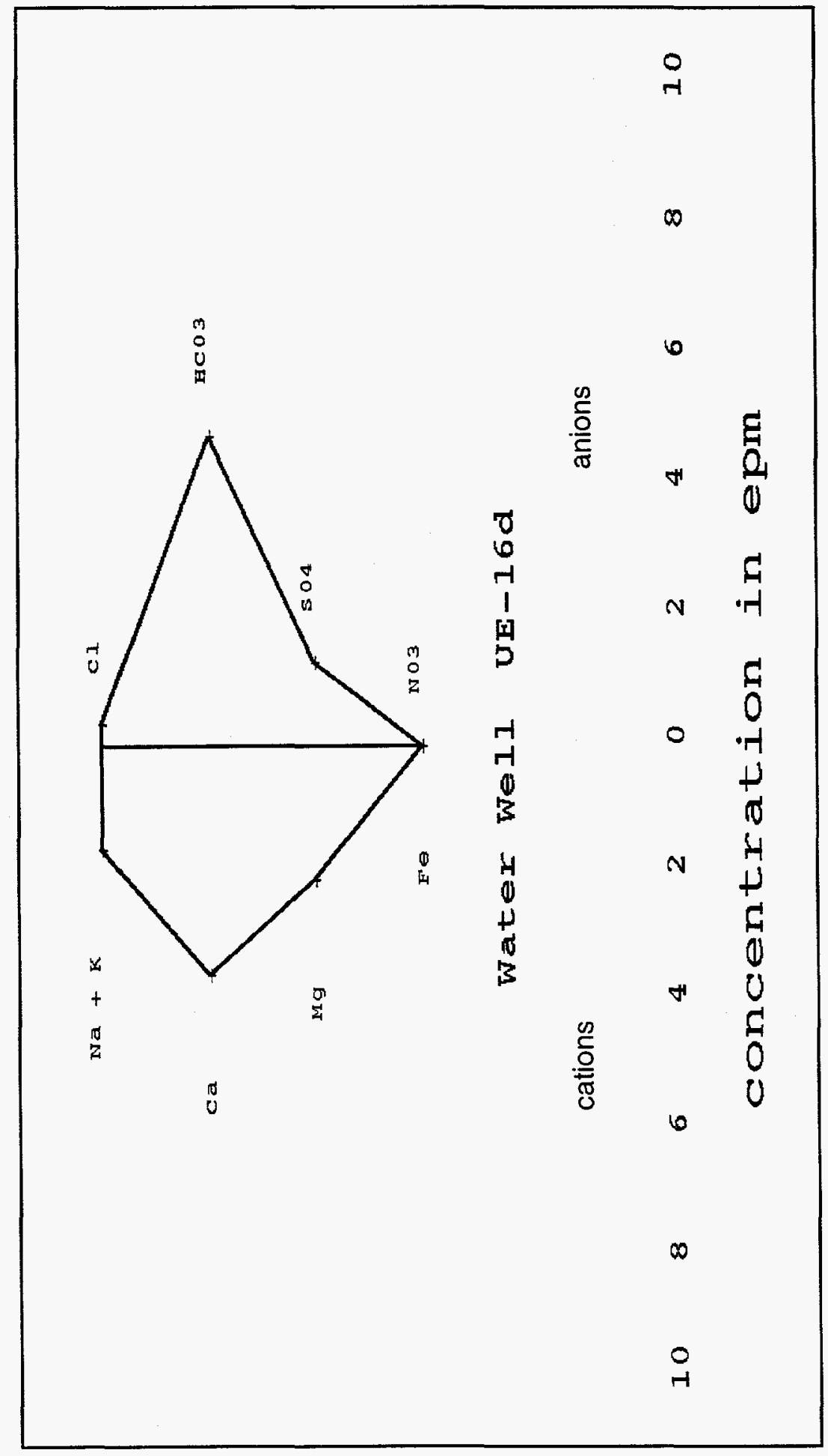




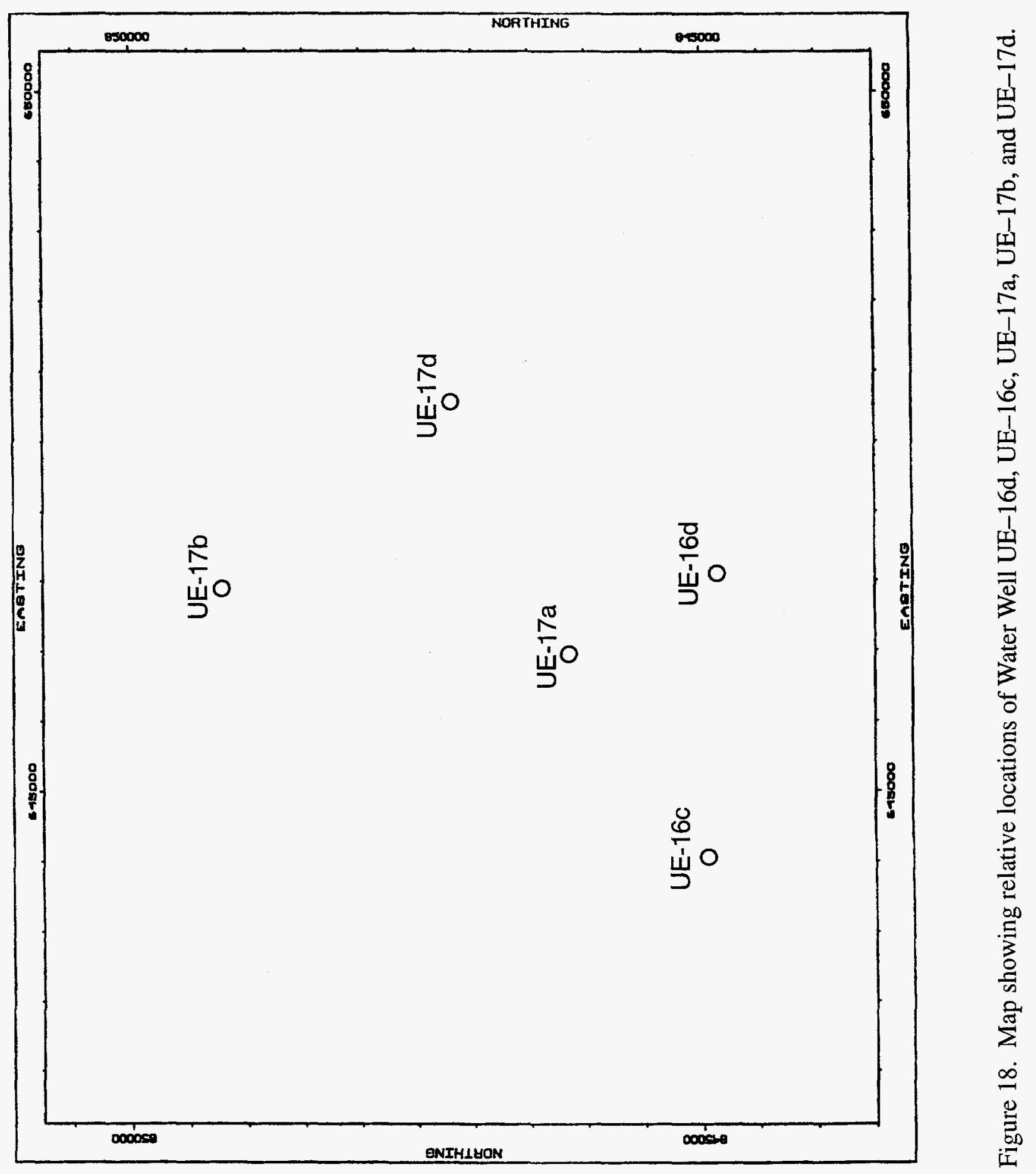




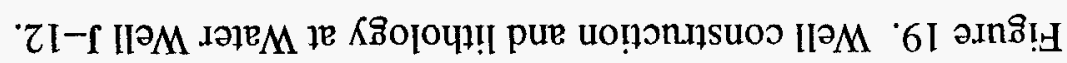

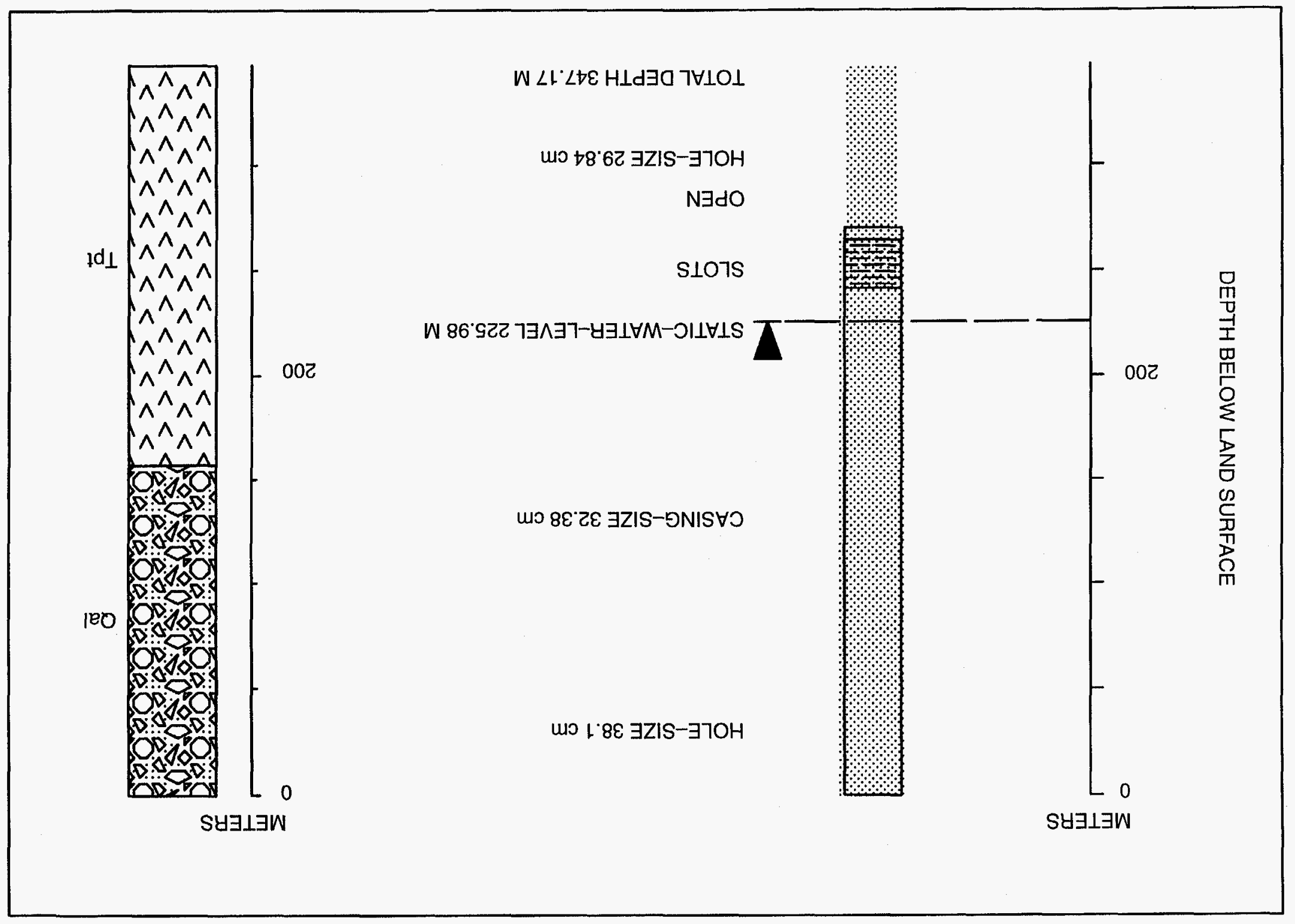


resulted in $3 \mathrm{~m}$ of drawdown at a pumping rate of $4850 \mathrm{~m}^{3} /$ day with a specific capacity of 1600 $\mathrm{m}^{3} /$ day/m of drawdown (Claassen, 1973). Mean transmissivity for Water Well J-12 is estimated as $1242 \mathrm{~m}^{2} /$ day (Winograd and Thordarson, 1975).

Water quality data from Water Well $\mathrm{J}-12$ indicate a $\mathrm{Na}+\mathrm{K}+\mathrm{HCO}_{3}$ water type typical of water from volcanic aquifers (Figure 20). Water production in Water Well J-12 originates from fractured welded ash-flow tuff units of the Topopah Spring member of the Paintbrush Tuff (Figure 20).

\section{Proximity to Underground Nuclear Tests and Existing Wells}

No underground tests or existing wells are located within $2 \mathrm{~km}$ of Water Well J-12.

\section{Existing Water Rights Permits}

Water rights permit number 57373, for Water Well J-12, was issued by the State of Nevada on 18 August 1992. The permit describes the point of diversion at Water Well J-12 to be: SW $1 / 4 \mathrm{NW} 1 / 4$, Section 6, T14S, R50E, M.D.B.\&M. at a point from which the SW corner of Section 6, said township and range, bears $\mathrm{S} 51^{\circ} 08^{\prime} 04^{\prime} \mathrm{W}$, a distance of 4332.31 feet. The permit allows a diversion rate of less than $1.0 \mathrm{ft}^{3} / \mathrm{sec}$ or less than 430.19 acre feet annually. The annual duty for Water Well J-12 is less than 430.19 acre feet. The type of use for water obtained from Water Well J-12 is described as industrial. The owner of record is DOE/NV.

\section{Water Well J-13}

Location

Water Well J-13 is located in Jackass Flats in the southwestern portion of the NTS (Figure 5). Land surface elevation at the well site is $954 \mathrm{~m}$ MSL. Water Well J-13 is located in the Alkali Flat-Furnace Creek Ranch subbasin groundwater flow system. Potentiometric data (Winograd and Thordarson, 1975) indicate the general direction of groundwater flow in the area of Water Well J-13 to be from north to south (Figure 3). Water Well J-13 is located approximately $4.75 \mathrm{~km}$ north of Water Well J-12.

\section{Construction/Completion}

Water Well J-13 (Figure 21) was originally drilled as USGS Hydrologic Test Hole \#6 in 1963. The borehole was constructed using rotary tools with conventional circulation. A 66-cm-diameter hole was drilled from the surface to $135.6 \mathrm{~m}$ using drilling mud and aerated mud. The remaining hole was drilled using air and air-foam. Surface casing, $45.7 \mathrm{~cm}$ in diameter, was placed in the 66- $\mathrm{cm}$-diameter hole to $135.6 \mathrm{~m}$. The annular space between this casing and the wellbore was cemented to the surface. A $43.8-\mathrm{cm}$-diameter hole was drilled from $135.6 \mathrm{~m}$ to $405.1 \mathrm{~m}$. A combined string of 34-cm-diameter (surface to $400.2 \mathrm{~m}$ ) and 29.8-cm-diameter ( 400.2 to $474.3 \mathrm{~m}$ ) casing was placed in the $43.8-\mathrm{cm}$-diameter hole and tack cemented at the bottom with $5 \mathrm{~m}^{3}$ of cement. A $38.1-\mathrm{cm}$-diameter hole was drilled from $474.3 \mathrm{~m}$ to $615.7 \mathrm{~m}$, and a $19.4-\mathrm{cm}$-diameter hole was drilled from $615.7 \mathrm{~m}$ to total depth at $1066.2 \mathrm{~m}$. A 14-cm-diameter liner was placed from $452.3 \mathrm{~m}$ to $1031.7 \mathrm{~m}$. The liner was not cemented within the wellbore. The liner contained a slotted interval from $822.6 \mathrm{~m}$ to $1012.2 \mathrm{~m}$. The combined casing string was perforated from $306.6 \mathrm{~m}$ to $426.7 \mathrm{~m}$. 


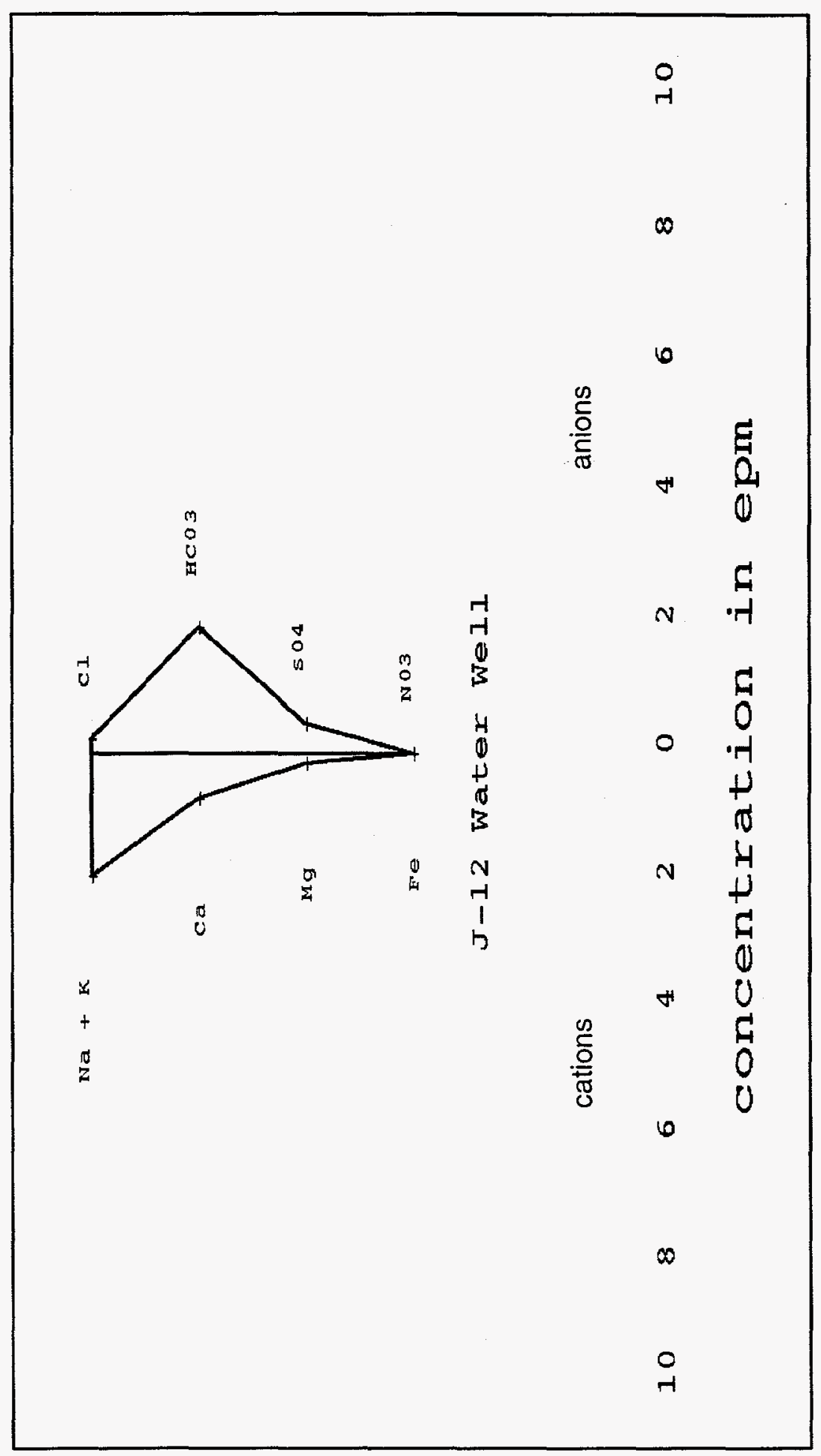

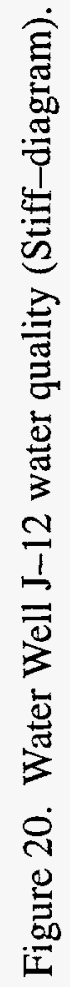


•

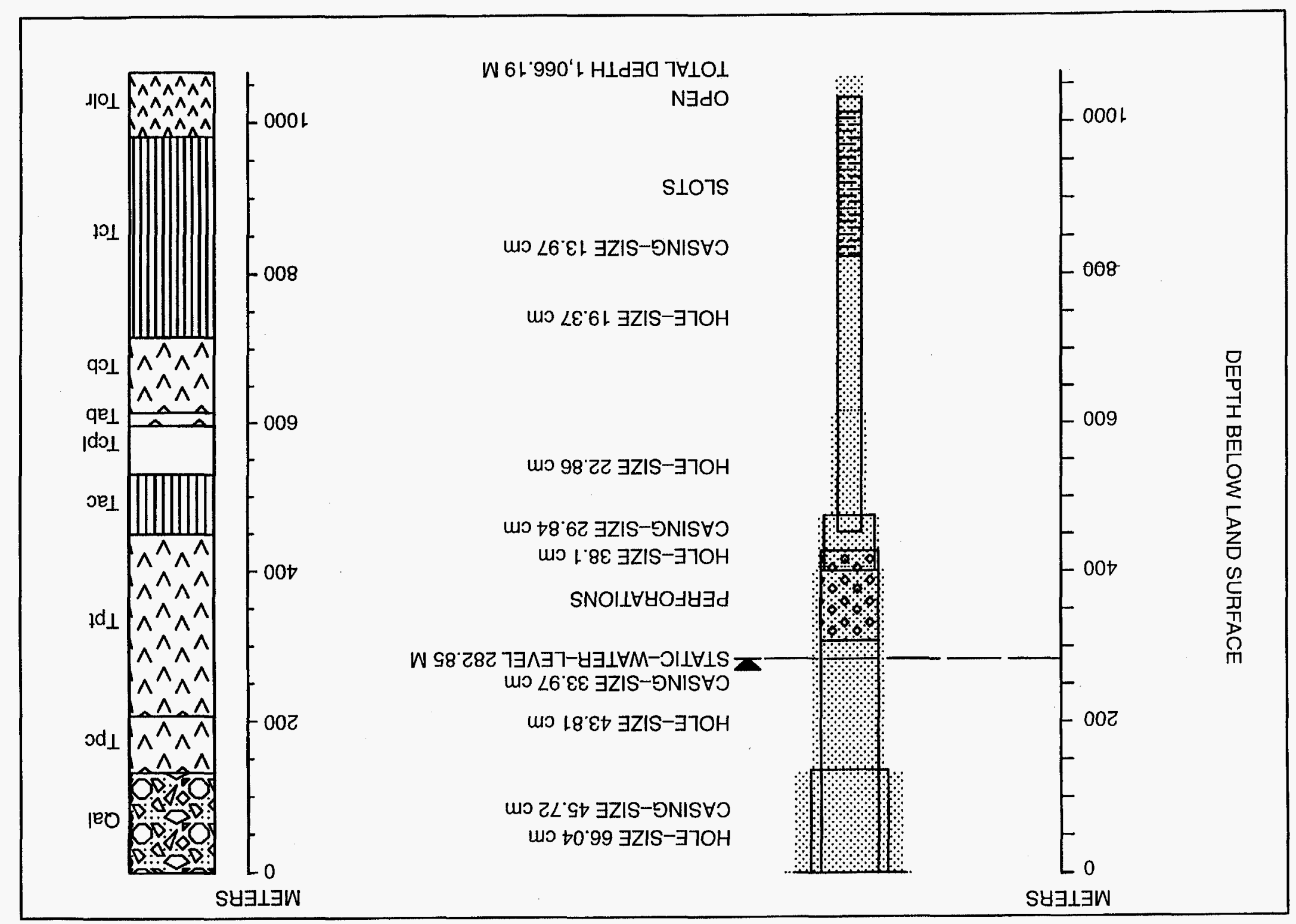




\section{Hydrogeology}

Static water level in Water Well J-13 is reported as $282.8 \mathrm{~m}$ below land surface. The latest production test, conducted in 1969 , resulted in $6.8 \mathrm{~m}$ of drawdown at a pumping rate of $3640 \mathrm{~m}^{3} /$ day with a specific capacity of $540 \mathrm{~m}^{3} / \mathrm{day} / \mathrm{m}$ of drawdown (Claassen, 1973). Mean transmissivity for Water Well J-13 is $845 \mathrm{~m}^{2} /$ day (Winograd and Thordarson, 1975).

Water quality data (Chapman and Lyles, 1993) from Water Well J-13 indicate a $\mathrm{Na}+\mathrm{K}+\mathrm{HCO}_{3}$ water type typical of water from volcanic aquifers (Figure 22). Major ion chemistry from Water Well $\mathrm{J}-13$ is almost identical to that from Water Well $\mathrm{J}-12$ with the exception of a slightly higher $\mathrm{Na}$ and $\mathrm{K}$ concentration in the water from Water Well $\mathrm{J}-13$. Water production in Water Well $\mathrm{J}-13$ appears to originate primarily from fractured welded ash-flow tuff units of the Topopah Spring member of the Paintbrush Tuff (as in Water Well J-12), with perhaps minor contributions from units of the Crater Flat Tuff (Figure 21).

\section{Proximity to Underground Nuclear Tests and Existing Wells}

No underground tests or existing wells are located within $2 \mathrm{~km}$ of Water Well J-13.

\section{Existing Water Rights Permits}

Water rights permit number 57376, for Water Well J-13, was issued by the State of Nevada on 18 August 1992. The permit describes the point of diversion at Water Well J-13 to be: NE1/4 SW $1 / 4$, Section 19, T13S, R50E, M.D.B.\&M. at a point from which the SW corner of Section 31, said township and range, bears $\mathrm{S} 08^{\circ} 46^{\prime} 06^{\prime} \mathrm{W}$, a distance of 13,298 feet. The permit allows a diversion rate of less than $0.8 \mathrm{ft}^{3} / \mathrm{sec}$ or less than 430.19 acre feet annually. The annual duty for Water Well J-13 is less than 430.19 acre feet. The type of use for water obtained from Water Well J-13 is described as industrial. The owner of record is DOE/NV.

\section{Water Well 8}

\section{Location}

Water Well 8 is located southeast of Pahute Mesa at the eastern edge of the Alkali Flat-Furnace Creek Ranch subbasin groundwater flow system (Figure 5). Land surface elevation at the drill site is $1735.7 \mathrm{~m}$ MSL. Potentiometric data (Winograd and Thordarson, 1975) indicate the general direction of groundwater flow in the area of Water Well 8 to be from north to south (Figure 3).

\section{Construction/Completion}

Water Well 8 (Figure 23) was drilled in 1962 using rotary tools with conventional circulation using air, air foam, mud and aerated mud. A $22.9-\mathrm{cm}$-diameter borehole was drilled to $619 \mathrm{~m}$. This hole was opened to $38.1-\mathrm{cm}$-diameter and $29.8-\mathrm{cm}$-diameter casing was installed to $619 \mathrm{~m}$. The bottom $45.7 \mathrm{~m}$ of annular space between this casing and the wellbore was cemented. A 19.4-cm-diameter hole was drilled from 619 to $1672.4 \mathrm{~m}$. A 15.6-cm-diameter core hole was cut from 1672.4 to total depth at $1673.3 \mathrm{~m}$. The borehole was opened to $27 \mathrm{~cm}$ from 618.7 to $895 \mathrm{~m}$ and a 7.6-cm-diameter liner was placed in the well from 591.6 to $895 \mathrm{~m}$. The liner was pre-slotted from 621.2 to $631 \mathrm{~m}$ and from 651.4 to $661.4 \mathrm{~m}$. The $34-\mathrm{cm}$ casing was gun perforated from 496.8 to 


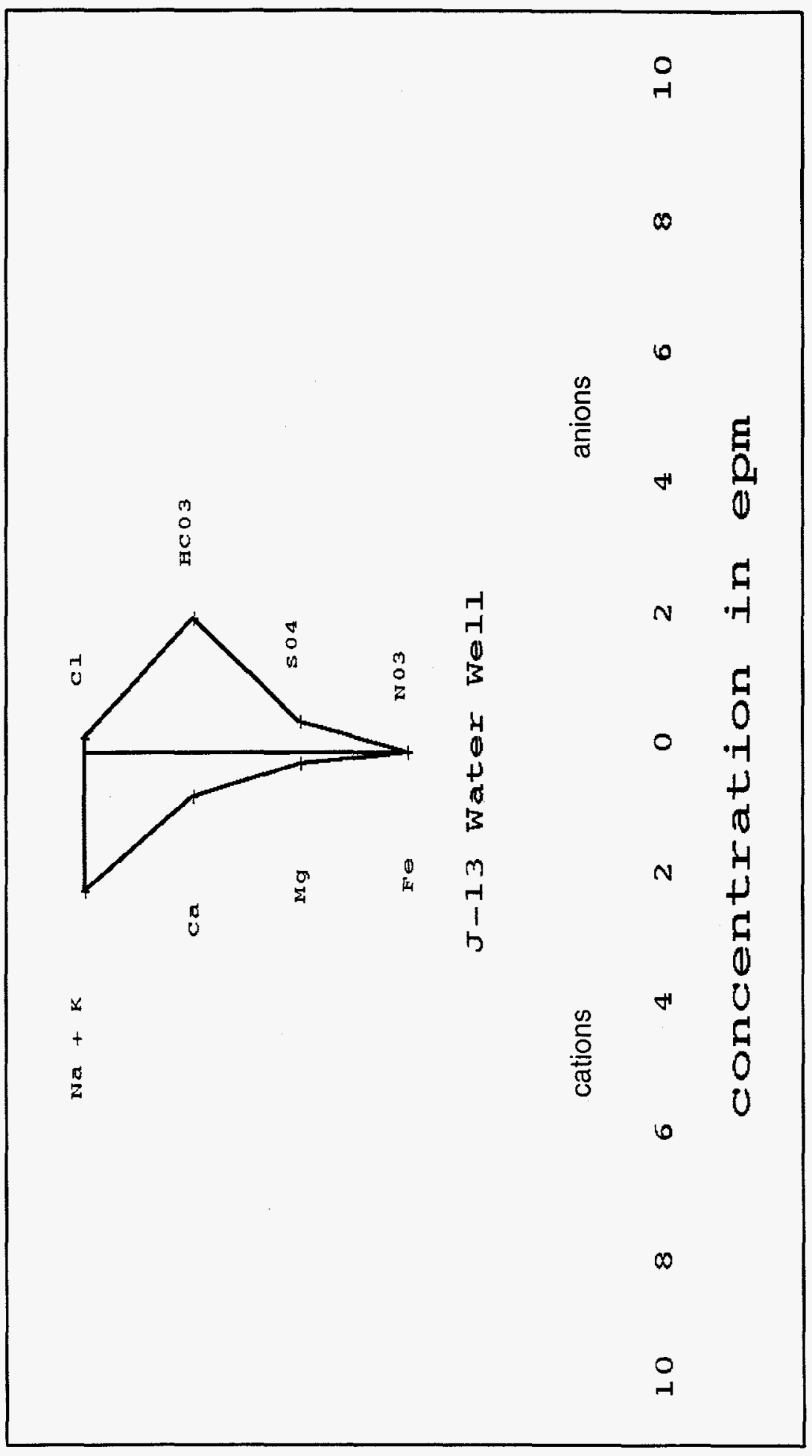

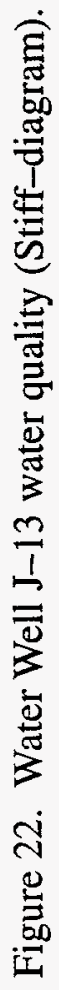


8 ІІРМ Јәте

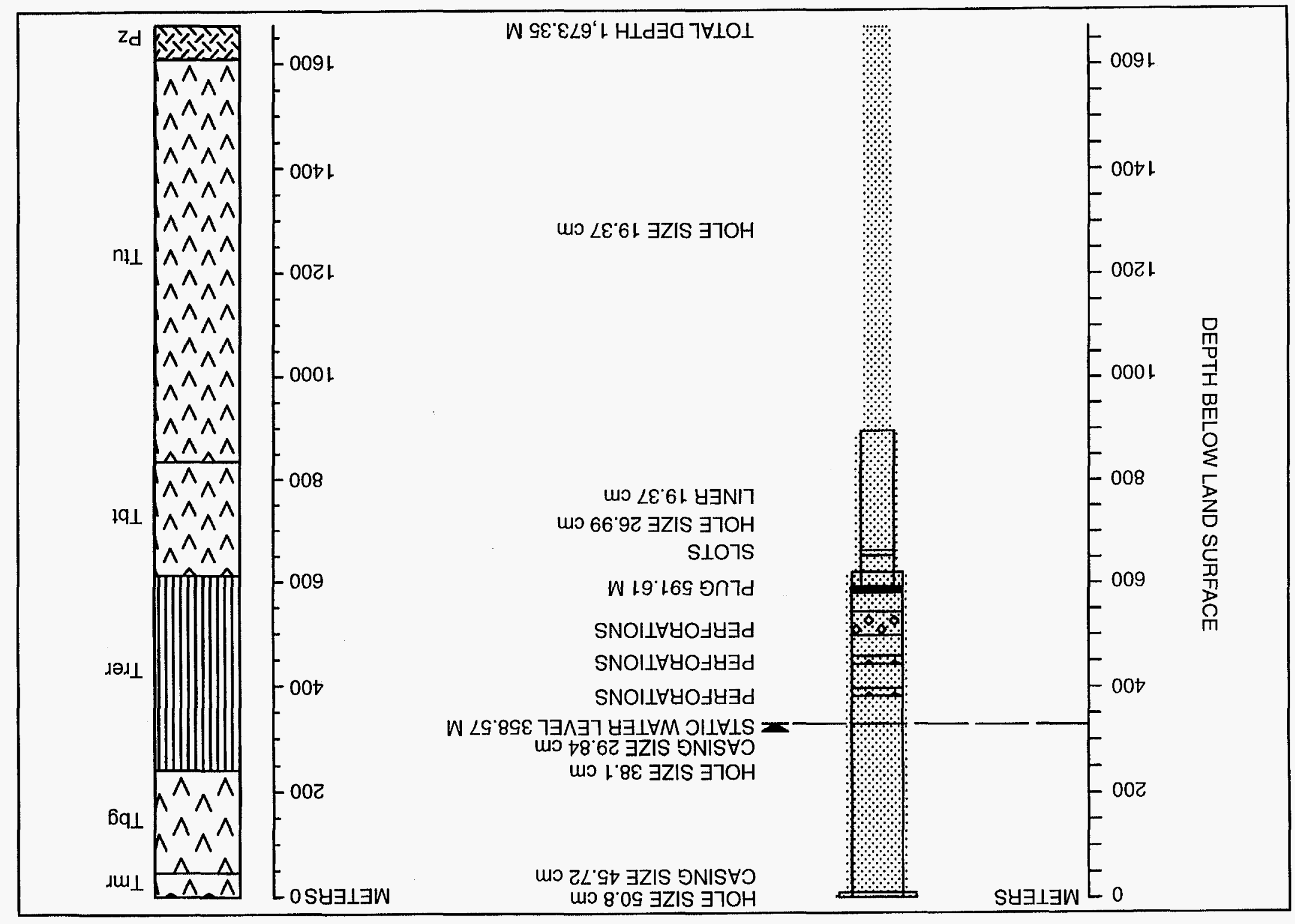


$542.5,442$ to 457.2 , and 381 to $396.2 \mathrm{~m}$. A retrievable bridge plug was then set at $591.6 \mathrm{~m}$ inside the $29.8-\mathrm{cm}$-diameter casing and a cement plug was placed inside liner and casing from the bridge plug up to $567.5 \mathrm{~m}$.

\section{Hydrogeology}

Static water level in Water Well 8 is reported at $328.6 \mathrm{~m}$ below land surface. A production test following installation of the pump indicated a production of $2180 \mathrm{~m}^{3} /$ day with a drawdown of 2.38 $\mathrm{m}$ (specific capacity of $920 \mathrm{~m}^{3} / \mathrm{day} / \mathrm{m}$ of drawdown). A production test in 1971 , conducted at a production rate of $3160 \mathrm{~m}^{3} /$ day with a drawdown of $8.9 \mathrm{~m}$ ), indicated a specific capacity for the well of $1200 \mathrm{~m}^{3} / \mathrm{day} / \mathrm{m}$ of drawdown (Claassen, 1973). Blankennagel and Weir (1973) reported an estimated transmissivity for Water Well 8 of $2298 \mathrm{~m}^{2} /$ day.

Water quality data (Chapman and Lyles, 1993) from the well indicate a $\mathrm{Na}+\mathrm{K}+\mathrm{HCO}_{3}$ water type typical of volcanic aquifers (Figure 24). Water production from Water Well 8 originates from rhyolitic lava flows with interbedded tuffs which comprise the Split Ridge stratigraphic unit (Figure 24).

\section{Proximity to Underground Nuclear Tests and Existing Wells}

No underground tests or existing wells are located within $2 \mathrm{~km}$ of Water Well 8.

\section{Water Well 4}

\section{Location}

Water Well 4 is located in northern CP Basin, northwest of Frenchman Flat (Figure 5). Land surface elevation at the well site is $1098.2 \mathrm{~m}$ MSL. Water Well 4 is located in the Ash Meadows subbasin groundwater flow system. Potentiometric data (Winograd and Thordarson, 1975) indicate the general direction of groundwater flow in the area of Water Well 4 to be from north to south (Figure 3).

\section{Construction/Completion}

Water Well 4 (Figure 25) was drilled in 1981 to a total depth of $450.8 \mathrm{~m}$ using rotary tools with conventional circulation using air-foam. A $66-\mathrm{cm}$-diameter hole was drilled to $193.8 \mathrm{~m}$; a $50.8-\mathrm{cm}$-diameter hole was then drilled to total depth at $450.8 \mathrm{~m}$. Water Well 4 was completed with $34-\mathrm{cm}$-diameter casing from $438.3 \mathrm{~m}$ to the surface. This casing was slotted from $287.1 \mathrm{~m}$ to 437.7 $\mathrm{m}$. The annular space between this casing and the wellbore was stemmed with pea gravel from total depth to $273.7 \mathrm{~m}$ (just above static water level in the well). The annular space above the gravel was not cemented. Following installation of the casing, the hole was cleaned out and reamed with a 44.4-cm-diameter bit from $437.7 \mathrm{~m}$ to $447.4 \mathrm{~m}$.

\section{Hydrogeology}

Static water level in Water Well 4 is reported at $286.8 \mathrm{~m}$ below land surface. The slotted gravel-packed interval in Water Well 4 penetrates units of the Rainier Mesa, Paintbrush, and Topopah Springs tuffs (Figure 25). The Rainier Mesa and Topopah Spring tuffs are described as nonwelded to densely welded ash-flow tuff units. The Paintbrush Tuffs are described as bedded tuff 


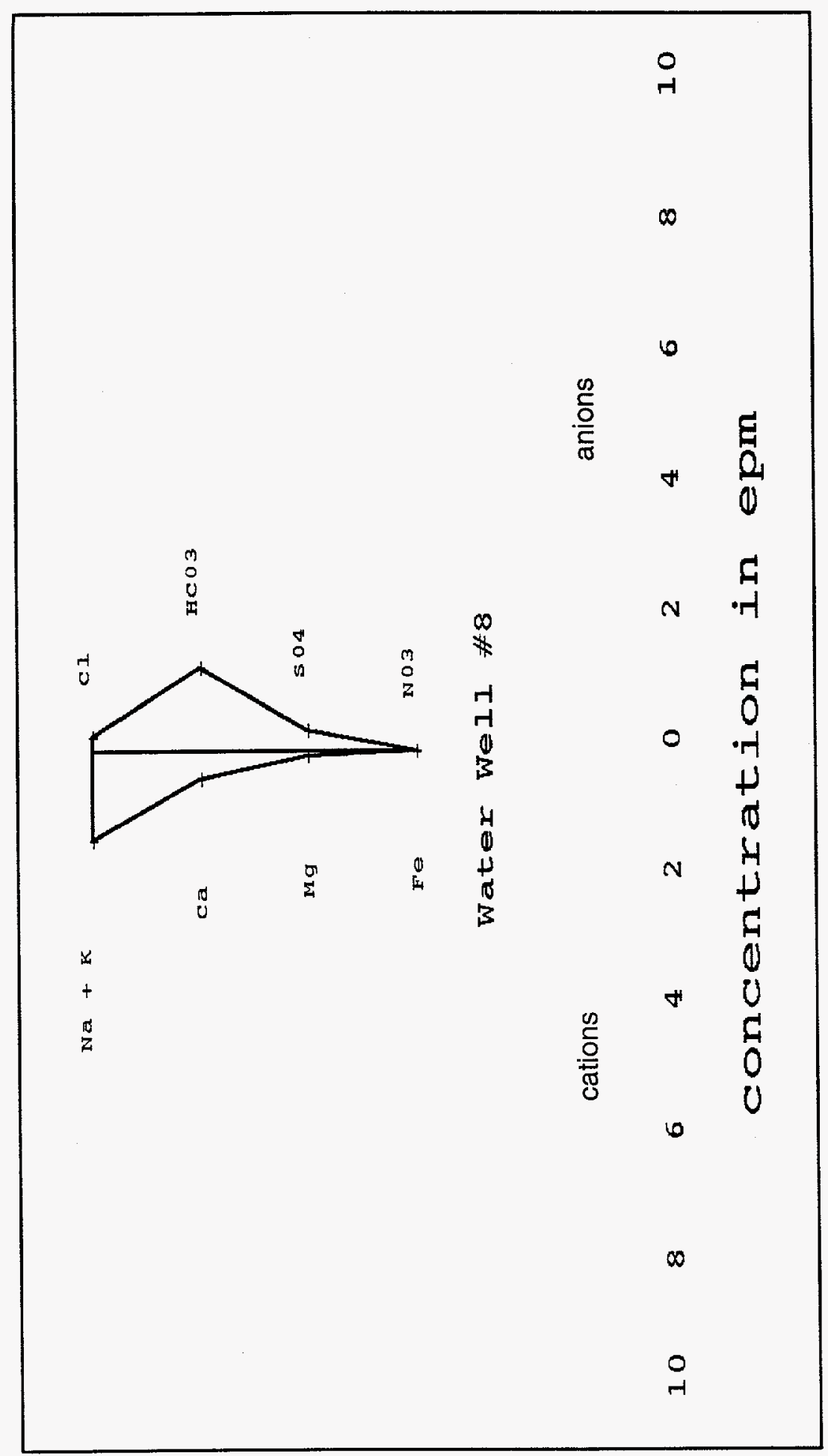

है 

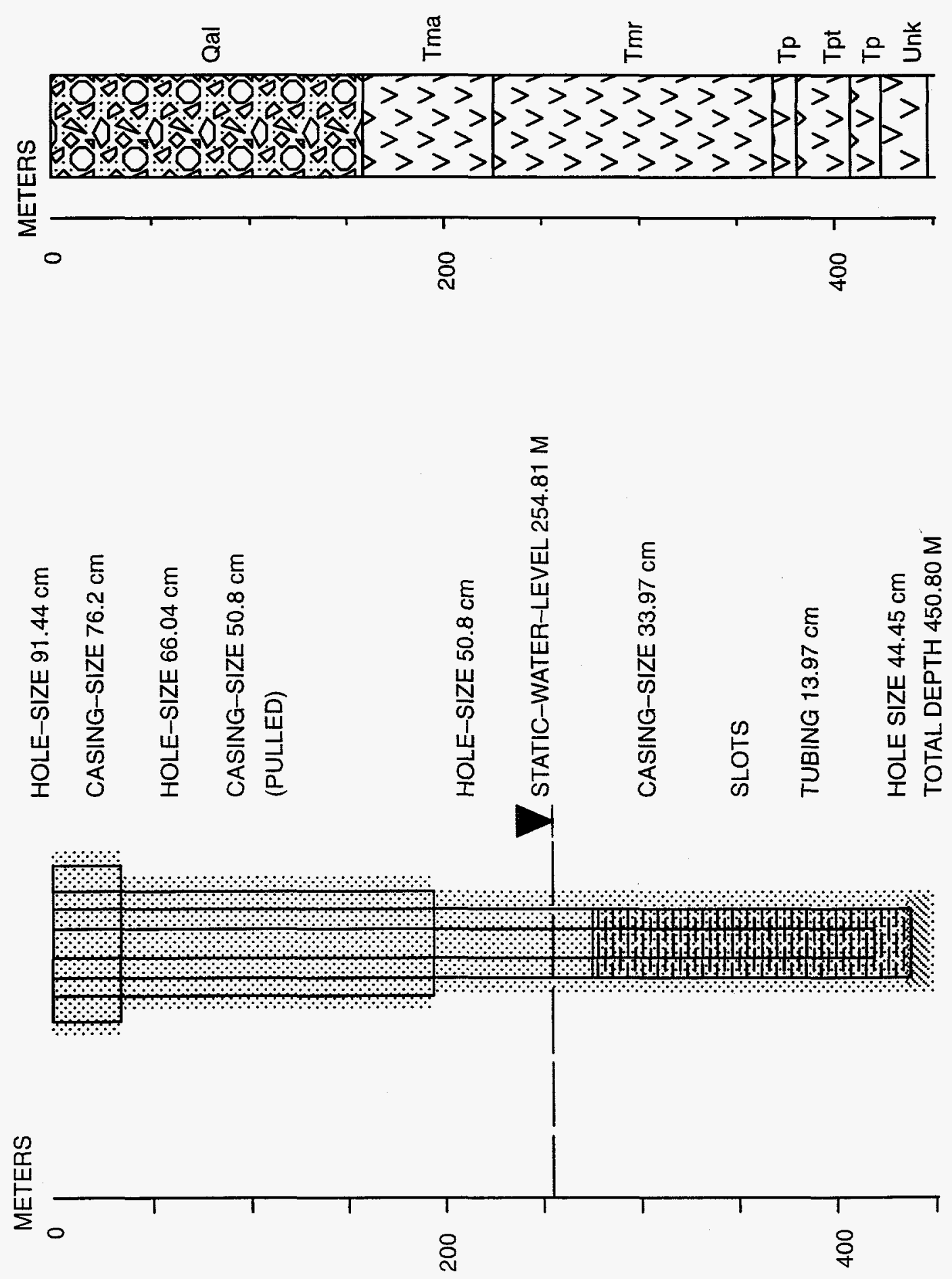

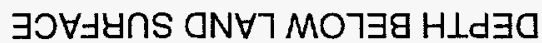


units. Water quality data (Chapman and Lyles, 1993) from the well indicate a $\mathrm{Na}+\mathrm{K}+\mathrm{HCO}_{3}$ water type, but with considerable $\mathrm{Ca}$ and $\mathrm{Mg}$ content compared to typical volcanic aquifers (Figure 26). Water production from Water Well 4 appears to originate primarily from fractures in the more densely welded portions of the Rainier Mesa and Topopah Spring tuff units penetrated by the well. NTS Site Maintenance Department records (unpublished) indicate a specific capacity of 140 $\mathrm{m}^{3} /$ day $/ \mathrm{m}$ of drawdown at a discharge rate of $3543 \mathrm{~m}^{3} /$ day.

\section{Proximity to Underground Nuclear Tests and Existing Wells}

No underground tests are located within $2 \mathrm{~km}$ of Water Well 4. Two existing wells, Water Well 4A and Water Well C-1, are located within $2 \mathrm{~km}$ of Water Well 4 (Figure 27). Water Well 4A is located $363.6 \mathrm{~m}$ southwest of Water Well 4 . Water Well C-1 is located $1.9 \mathrm{~km}$ northeast of Water Well 4.

\section{Water Well 4A}

\section{Location}

Water Well 4A is located in northern CP Basin, northwest of Frenchman Flat (Figure 5). Land surface elevation at the well site is $1099.0 \mathrm{~m}$ MSL. Water Well 4A is located in the Ash Meadows subbasin groundwater flow system. Potentiometric data (Winograd and Thordarson, 1975) indicate the general direction of groundwater flow in the area of Water Well 4A to be from north to south (Figure 3). Water Well 4A is located $363.6 \mathrm{~m}$ southwest of Water Well 4 and penetrates essentially the same hydrogeologic units as Water Well 4.

\section{Construction/Completion}

Water Well 4A (Figure 28) was drilled in 1990 to a total depth of $462.1 \mathrm{~m}$. An initial 76.2-cm-diameter hole was drilled to $163.4 \mathrm{~m}$ using rotary tools and conventional circulation with bentonite mud. This portion of the borehole was cased with $61-\mathrm{cm}$-diameter casing from the surface to $161.8 \mathrm{~m}$. The annular space between this casing and the borehole was cemented to the surface. A 52.1-cm-diameter hole was drilled to total depth at $462.1 \mathrm{~m}$ using rotary tools and conventional circulation with air-foam. The well was completed with $34-\mathrm{cm}$-diameter casing set from the surface to $457.5 \mathrm{~m}$. This casing contains slotted intervals from 416 to $444.1 \mathrm{~m}$ and from 324.9 to $390.4 \mathrm{~m}$. The annular space between the 34-cm-diameter casing and the wellbore was gravel packed from 287.7 to $457.8 \mathrm{~m}$ (just below the static water level in the well) with pea gravel. No cement was placed in the annular space above the gravel pack.

\section{Hydrogeology}

Static water level in Water Well 4A is reported at $254.5 \mathrm{~m}$ below land surface. The slotted gravel-packed intervals in Water Well 4 penetrate units of the Ammonia Tanks, Rainier Mesa, Pre-Rainier Mesa, Paintbrush/Topopah Springs and Calico Hills tuffs (Figure 28). The Ammonia Tanks, Rainier Mesa and Paintbrush/Topopah Spring tuffs are described as nonwelded to densely welded ash-flow tuff units. The Pre-Rainier Mesa and Calico Hills tuffs are described as bedded tuff units. Water production from Water Well 4A appears to originate primarily from fractures in the more densely welded portions of the Rainier Mesa and Paintbrush/Topopah Spring tuff units 


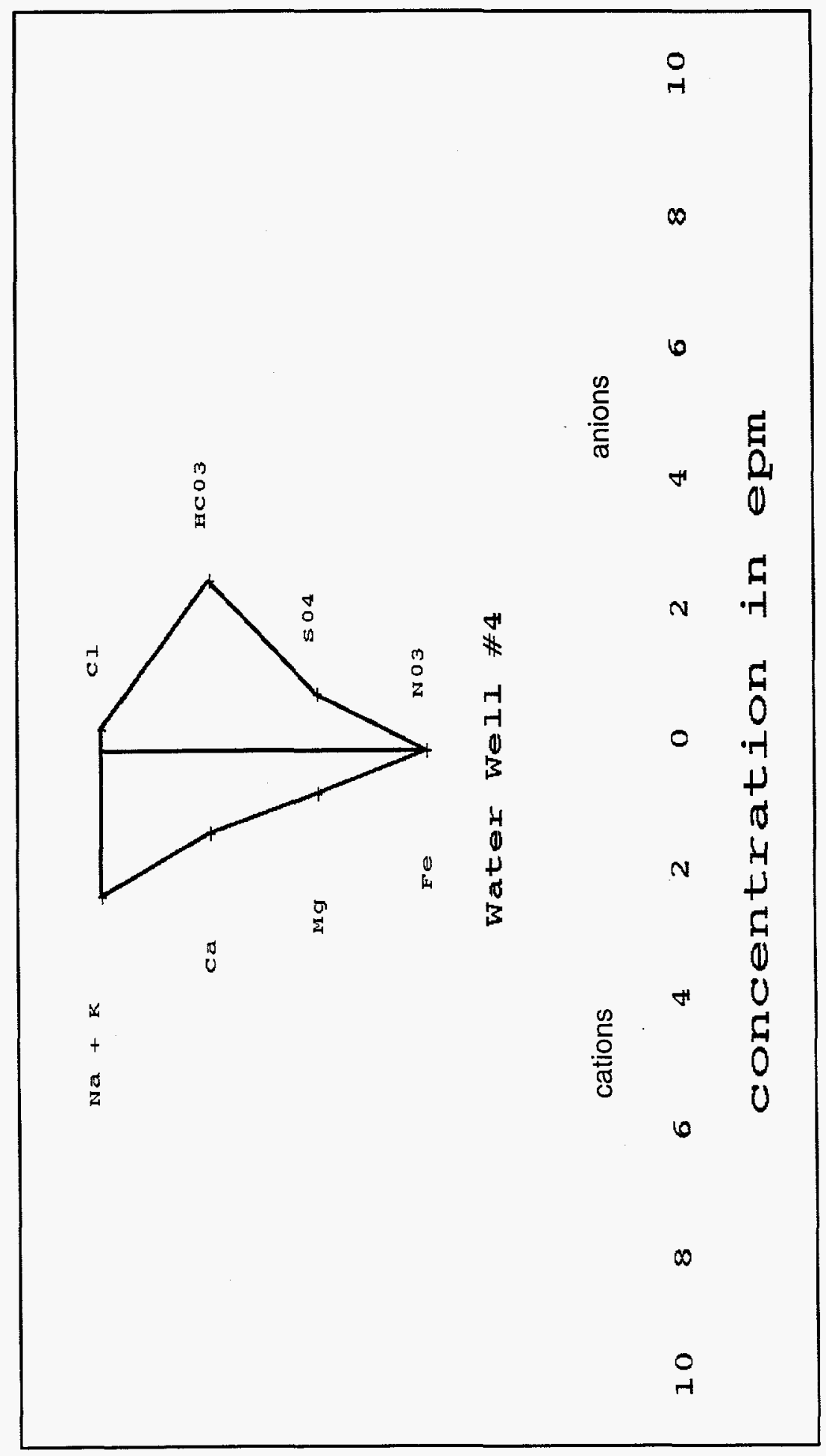

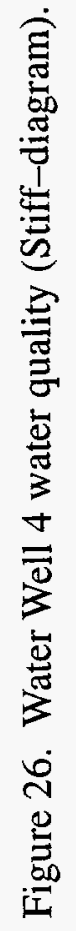




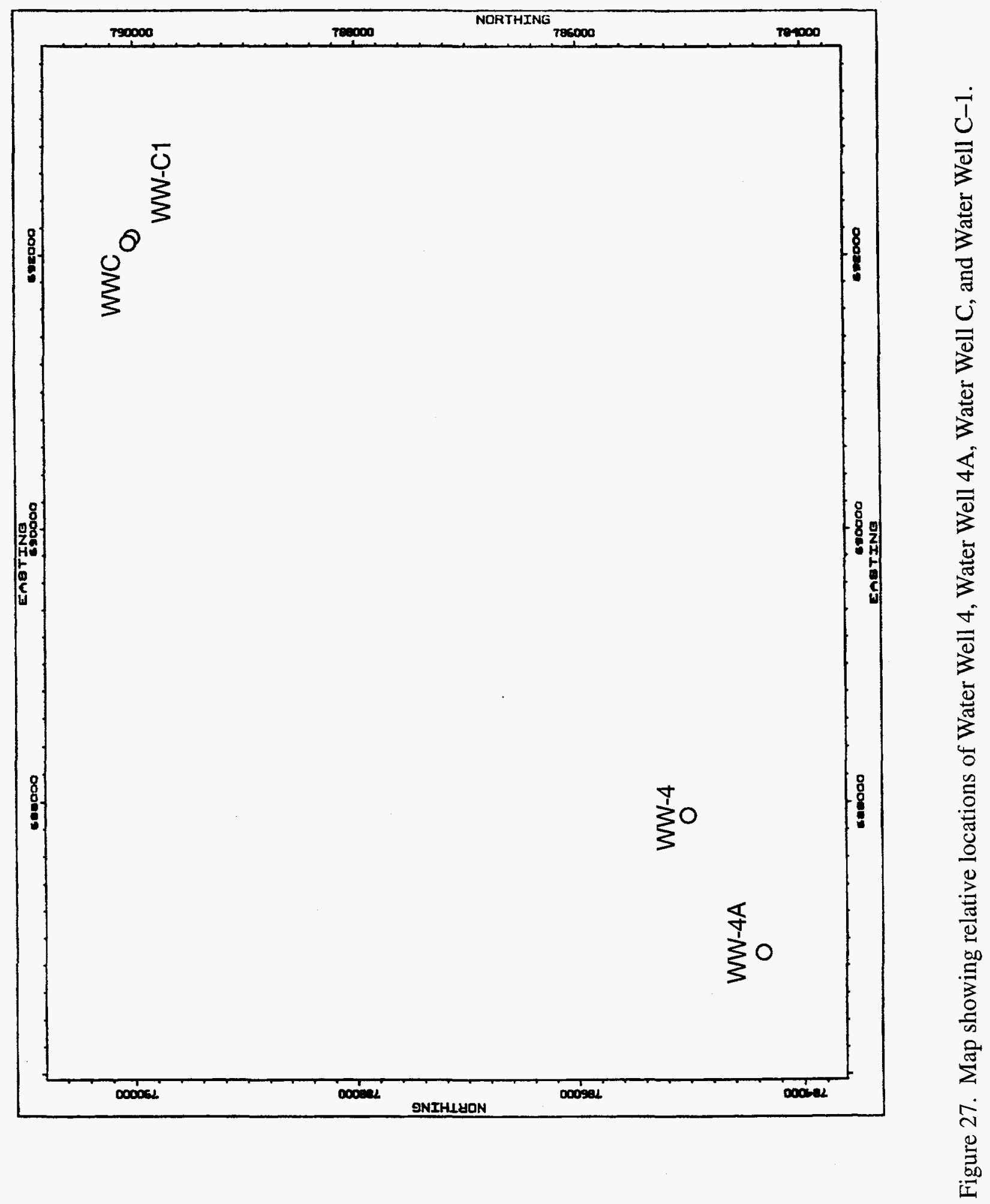




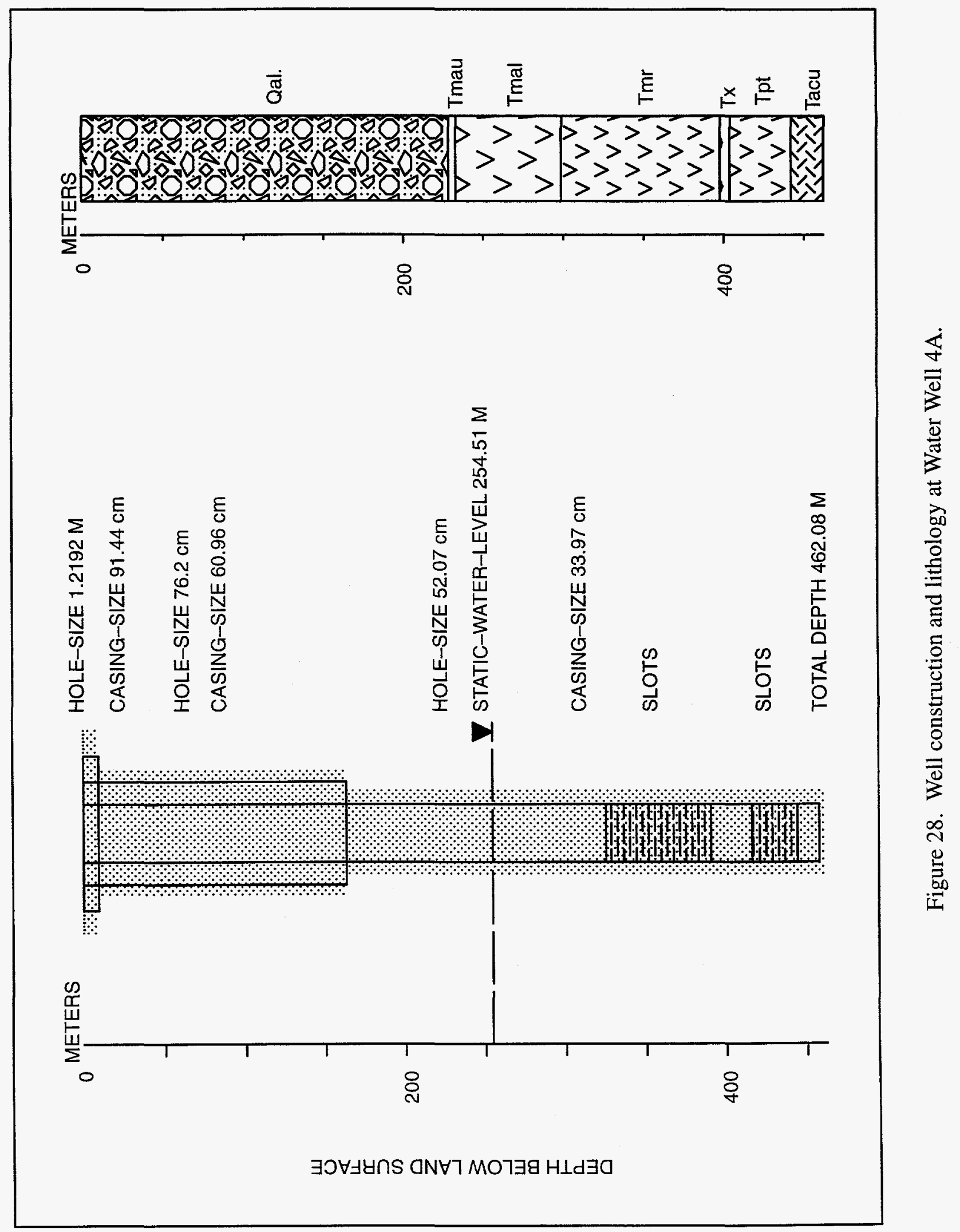


penetrated by the well with some contribution from the Ammonia Tanks Tuff. Water quality data are not available for Water Well 4A but are assumed to be similar to that found in Water Well 4 (Figure 26). NTS Site Maintenance Department records (unpublished) indicate a specific capacity of $321 \mathrm{~m}^{3} /$ day $/ \mathrm{m}$ of drawdown at a discharge rate of $3816 \mathrm{~m}^{3} /$ day.

Proximity to Underground Nuclear Tests and Existing Wells

No underground tests are located within $2 \mathrm{~km}$ of Water Well 4A. One existing well, Water Well 4 , is located within $2 \mathrm{~km}$ of Water Well 4A (Figure 27).

\section{Water Well C}

Location

Water Well $\mathrm{C}$ is located in extreme southern Yucca Flat (Figure 5). Land surface elevation at the well site is $1195.2 \mathrm{~m}$ MSL. Water Well C is located in the Ash Meadows subbasin groundwater flow system. Potentiometric data (Winograd and Thordarson, 1975) indicate the general direction of groundwater flow in the area of Water Well C to be from north to south (Figure 3).

\section{Construction/Completion}

The borehole at Water Well C (Figure 29) was drilled in 1961 to a total depth of $518.5 \mathrm{~m}$ using a combination of rotary and cable tools. A $38.1-\mathrm{cm}$-diameter hole was drilled to $494.4 \mathrm{~m}$, where severe hole sloughing conditions were encountered. To control the sloughing, a string of 32.4-cm-diameter casing was set in the borehole to a depth of $418.5 \mathrm{~m}$ and tack cemented in the borehole at the top and bottom. Cable tools were used to open and drill the hole from $418.5 \mathrm{~m}$ to total depth at $518.5 \mathrm{~m}$. A 27.3 -cm-diameter liner casing was placed in the well from 413.3 to 518.5 $\mathrm{m}$. This liner contained a slotted interval from 478.8 to $511.8 \mathrm{~m}$.

Water Well C was recompleted in 1967 with the removal of approximately $67 \mathrm{~m}$ of the 27.3-cm-diameter slotted liner casing from the well. The remainder of the 27.3-cm-diameter slotted liner casing was drilled out to a depth of $495.4 \mathrm{~m}$. A new string of $27.3-\mathrm{cm}$-diameter liner was then placed in the well from 404.2 to $495 \mathrm{~m}$. The new 27.3-cm-diameter liner contained slots on the bottom two joints (approximately the bottom $20 \mathrm{~m}$ ).

\section{Hydrogeology}

Static water level in Water Well $\mathrm{C}$ is reported at $469.7 \mathrm{~m}$ below land surface. Water Well C penetrates the contact between Tertiary volcanics and Paleozoic carbonates at $413 \mathrm{~m}$ below land surface. Water produced from Water Well C originates entirely from the Carrara Formation of the lower carbonate aquifer (Figure 30). Water quality data (Chapman and Lyles, 1993) from Water Well $\mathrm{C}$ indicate a $\mathrm{Na}+\mathrm{Ca}+\mathrm{Mg}+\mathrm{HCO}_{3}$ water type (Figure 30). This "mixed" water type is indicative of the contribution of water from volcanic units, either by downward leakage or by lateral flow from structurally juxtaposed formations (Chapman and Lyles, 1993). Production tests conducted at Water Well C are inconclusive due to the high transmissivity of the well, however, NTS Site Maintenance Department production records (unpublished) indicate a specific capacity of approximately 10,373

$\mathrm{m}^{3} /$ day $/ \mathrm{m}$ of drawdown at a discharge rate of $1581 \mathrm{~m}^{3} /$ day. Estimated mean transmissivity for Water Well $\mathrm{C}$ is $11,180 \mathrm{~m}^{2} /$ day (Winograd and Thordarson, 1975). 

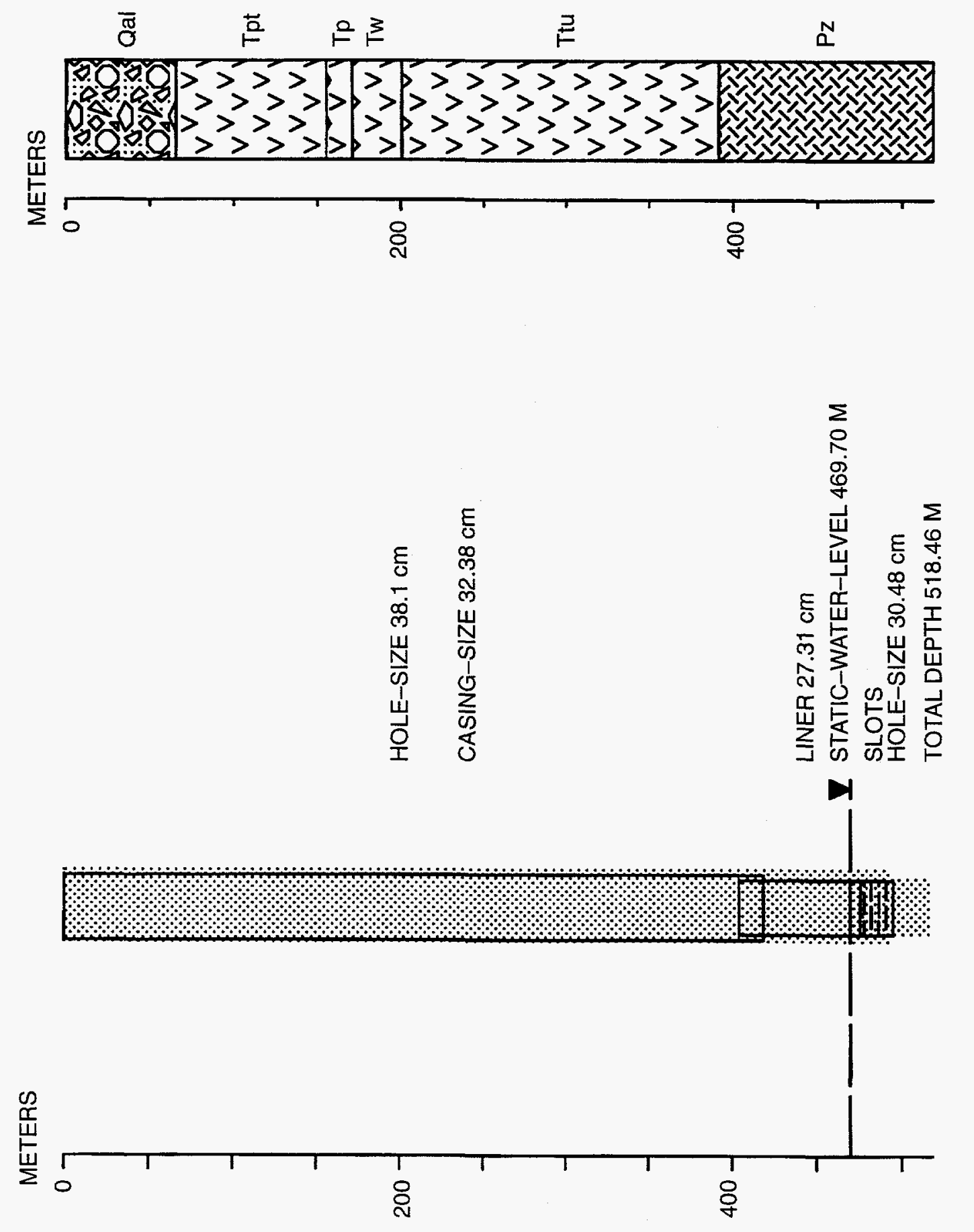

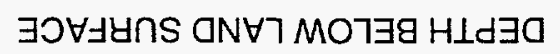




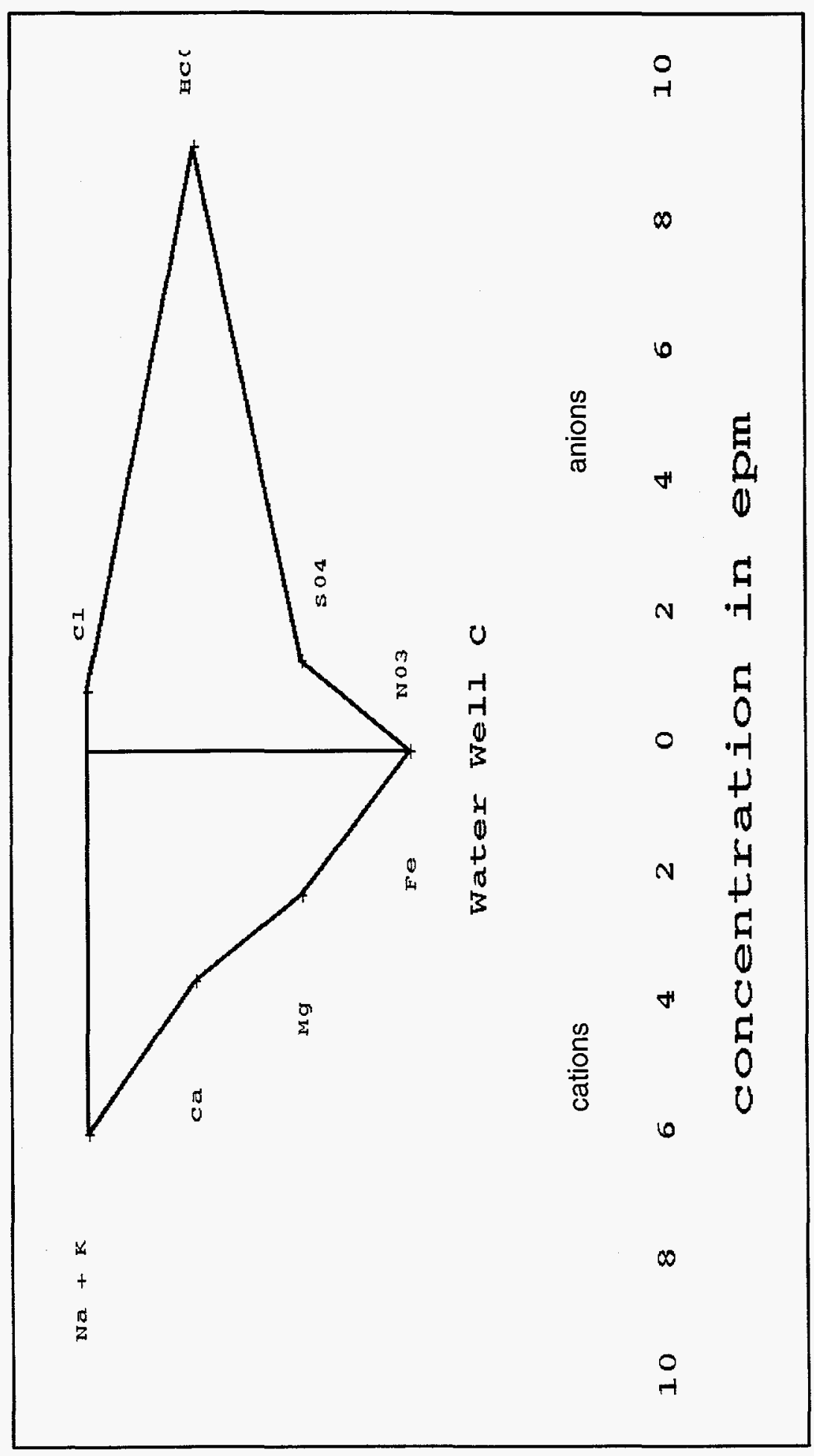


Proximity to Underground Nuclear Tests and Existing Wells

No underground tests are located within $2 \mathrm{~km}$ of Water Well C. One existing well, Water Well $\mathrm{C}-1$, is located within $2 \mathrm{~km}$ of Water Well C (Figure 27). Water Well C-1 is located $30.5 \mathrm{~m}$ southeast of Water Well C.

\section{Water Well C-1}

\section{Location}

Water Well C-1 (Figure 5) is located in extreme southern Yucca Flat. Land surface elevation at the well site is $1195.1 \mathrm{~m}$ MSL. Water Well C-1 is located in the Ash Meadows subbasin groundwater flow system. Potentiometric data (Winograd and Thordarson, 1975) indicate the general direction of groundwater flow in the area of Water Well C-1 to be from north to south (Figure 3).

\section{Construction/Completion}

Water Well C-1 (Figure 31) was drilled in 1962 to a total depth of $502.9 \mathrm{~m}$ using both rotary and cable tools. Air and mud were used to circulate cuttings from the hole. A 91.4-cm-diameter hole was drilled to $277.4 \mathrm{~m}$, and 61-cm-diameter casing placed in the hole with the annular space between this casing and the borehole was cemented to the surface. Following placement of this casing, the hole was drilled and reamed to $57.5-\mathrm{cm}$-diameter from $278.6 \mathrm{~m}$ to $486.5 \mathrm{~m}$ below land surface. A 47.3-cm-diameter hole was drilled to total depth at $520.3 \mathrm{~m}$. Following construction of the borehole, the original borehole was sidetracked from $423.4 \mathrm{~m}$ to $502.9 \mathrm{~m}$ below land surface due to the loss of equipment in the original borehole. A 42.2-cm-diameter liner casing was set in the sidetracked borehole from $259.1 \mathrm{~m}$ to $502.9 \mathrm{~m}$ below land surface. This liner was not cemented within the wellbore, and was perforated from $468.2 \mathrm{~m}$ to $502.9 \mathrm{~m}$ below land surface. It is of interest to note that during drilling of the sidetrack borehole, circulation was lost at Water Well C-1 (no returns to surface), however, foam returned to the surface in Water Well C.

\section{Hydrogeology}

Static water level in Water Well C is reported at $470 \mathrm{~m}$ below land surface. As in Water Well C, water produced from Water Well C-1 originates entirely from the Carrara Formation of the lower carbonate aquifer (Figure 31). Winograd and Thordarson (1975) indicated that water entry into the well was chiefly from the interval between 489.7 and $494.7 \mathrm{~m}$. Production records at Water Well C-1 indicate at specific capacity of approximately $519 \mathrm{~m}^{3} / \mathrm{day} / \mathrm{m}$ of drawdown at a discharge rate of $1581 \mathrm{~m} 3 /$ day. Estimated mean transmissivity for Water Well C-1 is approximately $75 \mathrm{~m}^{2} /$ day (Winograd and Thordarson, 1975). Water quality data (Chapman and Lyles, 1993) from Water Well $\mathrm{C}-1$ are similar to that from Water Well $\mathrm{C}$, but with slightly lower concentrations of $\mathrm{Na}, \mathrm{K}$, and $\mathrm{Ca}$ concentrations (Figure 32).

\section{Proximity to Underground Nuclear Tests and Existing Wells}

No underground tests are located within $2 \mathrm{~km}$ of Water Well C-1. Two existing wells, Water Well 4 and Water Well C, are located within $2 \mathrm{~km}$ of Water Well C-1 (Figure 27). 


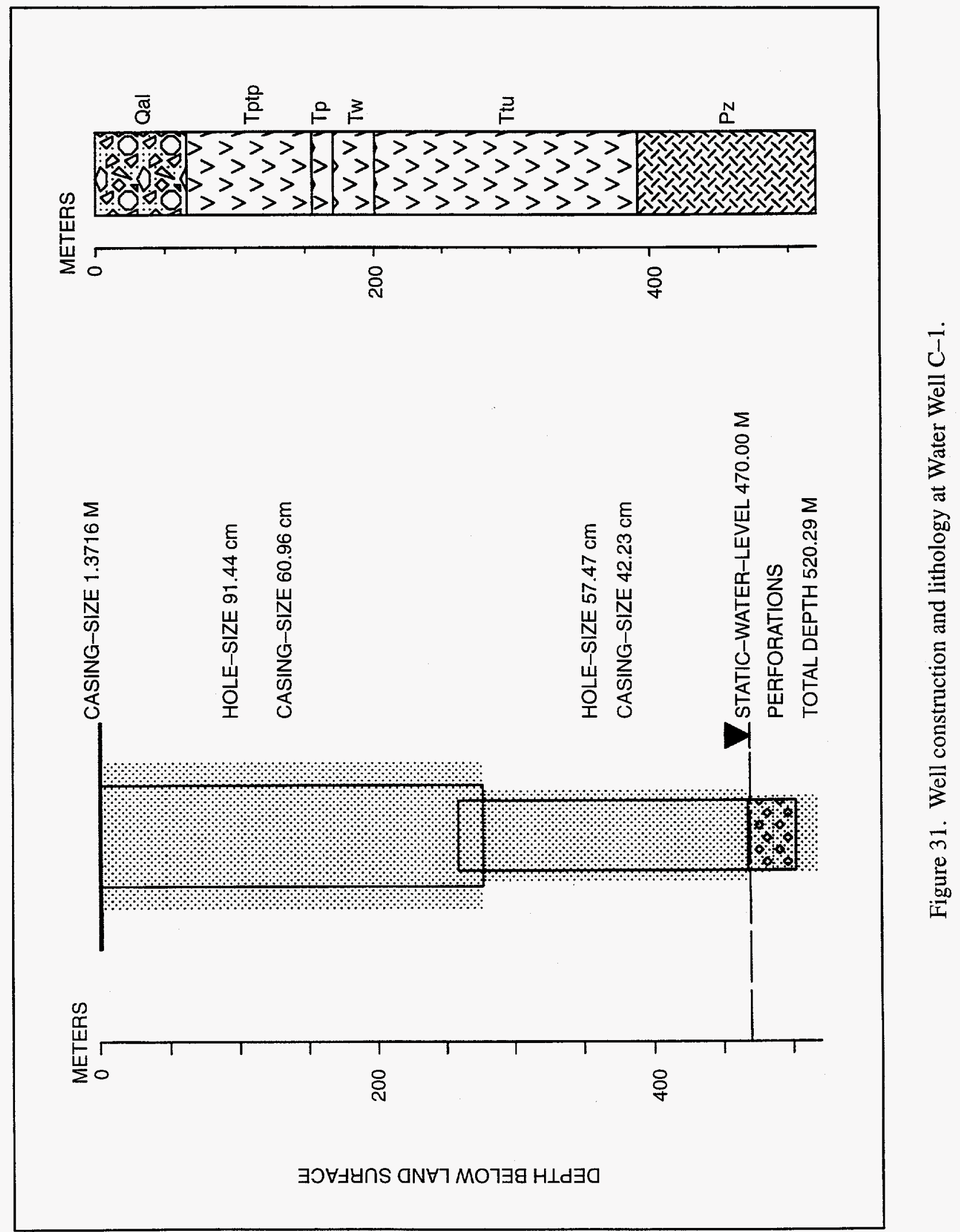




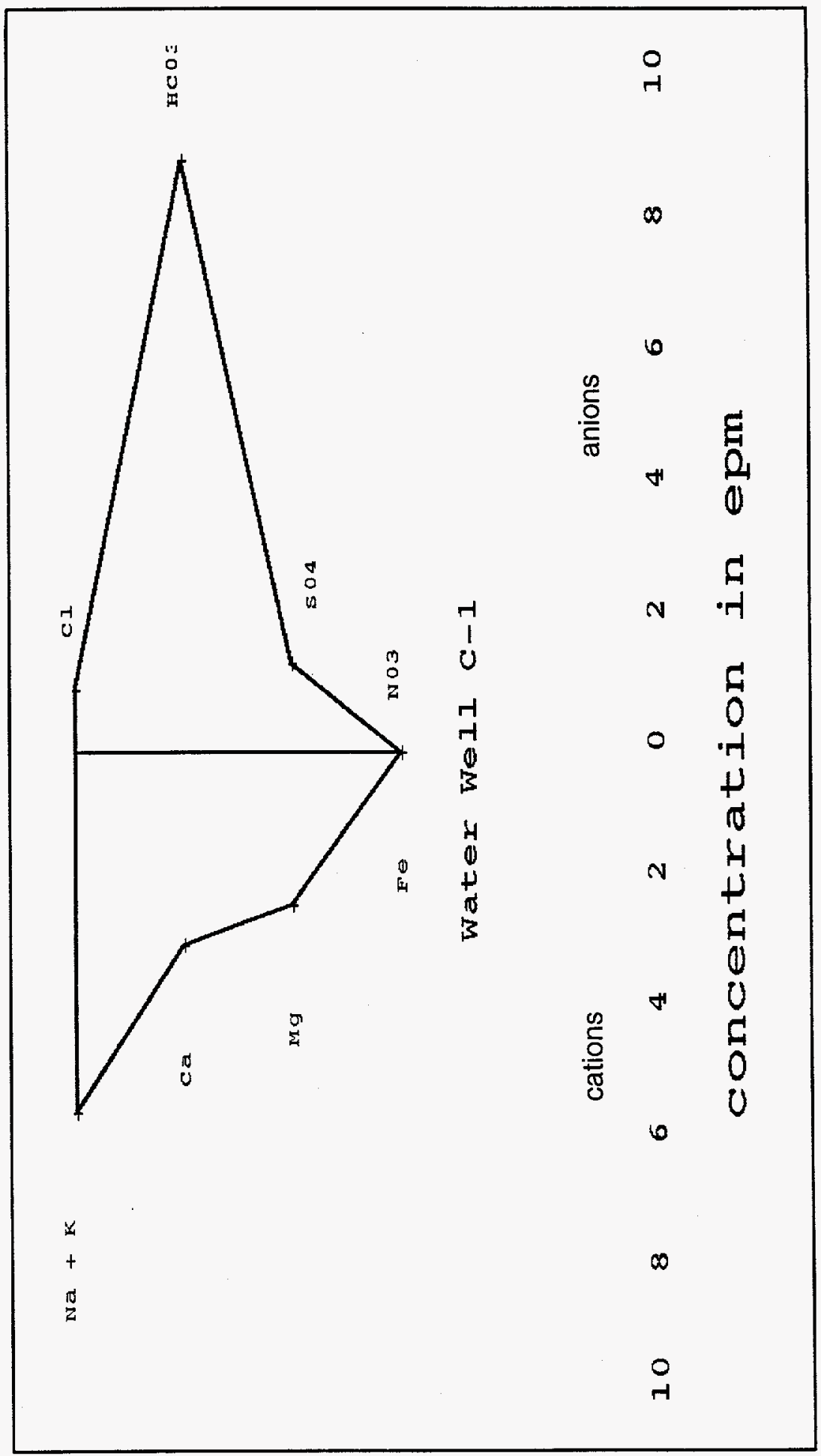

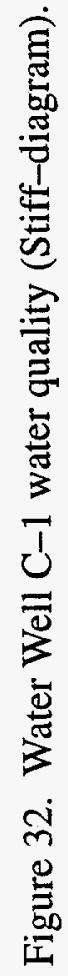




\section{Water Well 2}

Location

Water Well 2 (Figure 5) is located in northern Yucca Flat in the Ash Meadows subbasin groundwater flow system. Elevation at the well site is $1362.5 \mathrm{~m}$ MSL. Potentiometric data (Winograd and Thordarson, 1975) indicate the general direction of groundwater flow in the area of Water Well 2 to be from the northwest toward the southeast (Figure 3).

\section{Construction/Completion}

Water Well 2 (Figure 33) was drilled using both rotary and cable tools in 1962. A $38.1-\mathrm{cm}$-diameter hole was drilled to $480 \mathrm{~m}$, but $48.5 \mathrm{~m}$ of rotary tools were lost when the drilling string became stuck in the hole. The hole was then whipstocked at $365.8 \mathrm{~m}$ and the side-tracked hole drilled to $485.8 \mathrm{~m}$ below land surface. The $38.1-\mathrm{cm}$-diameter drillhole was then cased with 29.8 -cm-diameter casing to $446.5 \mathrm{~m}$. The annular space between this casing and the wellbore was tack cemented at the bottom and at the surface. Cable tools were then used to drill a 27.9-cm-diameter hole to $777.2 \mathrm{~m}$. Casing, $21.9 \mathrm{~cm}$ in diameter, was then placed in the hole and cable tools were used to drill a $20-\mathrm{cm}$-diameter hole to $822 \mathrm{~m}$. The 20 -cm-diameter hole was then under-reamed with an 27.9-cm-diameter bit and the 21.9-cm-casing was lowered to $781.2 \mathrm{~m}$. The 21.9-cm-casing was not cemented in place. Drilling of Water Well 2 was completed using rotary tools to drill a $20-\mathrm{cm}$ hole to a total depth of $1043 \mathrm{~m}$ below land surface. Construction of the well was completed with the placing of 16.8-cm-diameter liner casing from 762 to $823 \mathrm{~m}$. This liner was perforated between 762 and $823 \mathrm{~m}$ below land surface.

\section{Hydrogeology}

Fluid level in Water Well 2 is reported at $626.4 \mathrm{~m}$ below land surface. Water Well 2 penetrates both Tertiary volcanic and Paleozoic carbonate units in the saturated interval. The contact between Tertiary volcanic and Paleozoic units occurs at a depth of $780.3 \mathrm{~m}$ (Figure 33).

NTS Site Maintenance Department records (unpublished) indicate a specific capacity of 10.8 $\mathrm{m}^{3} /$ day $/ \mathrm{m}$ of drawdown at a discharge rate of $927 \mathrm{~m}^{3} /$ day. Water quality data (Chapman and Lyles, 1993) from the well indicate a $\mathrm{Ca}+\mathrm{Mg}+\mathrm{HCO}_{3}$ water type typical of carbonate aquifers (Figure 34). Although the perforations in the well casing are located within the carbonate interval in the well, the liner was not cemented in place, and it is possible the saturated portion of the volcanic interval may contribute to water produced from the well. The saturated portion of the volcanic interval in the well is composed of the Oak Springs Tuff. The Oak Springs Tuff penetrated by Water Well 2 is described as having a zeolitized or a clayey matrix, indicating minimal permeability.

\section{Proximity to Underground Nuclear Tests and Existing Wells}

One underground nuclear test (U-2ax), located within $25 \mathrm{~m}$ or below the water table, and five existing wells (UE-8d, UE-8f, UE-8i, UE-8h, and Jangle Test Hole \#A2) are located within $2 \mathrm{~km}$ of Water Well 2 (Figure 35). Underground test U-2ax is located downgradient from Water Well 2. Of the existing wells located upgradient of Water Well 2 (UE-8f, UE-8i, and UE-8h), only well UE-8f penetrates the carbonate interval below the water table (Figure 36). 


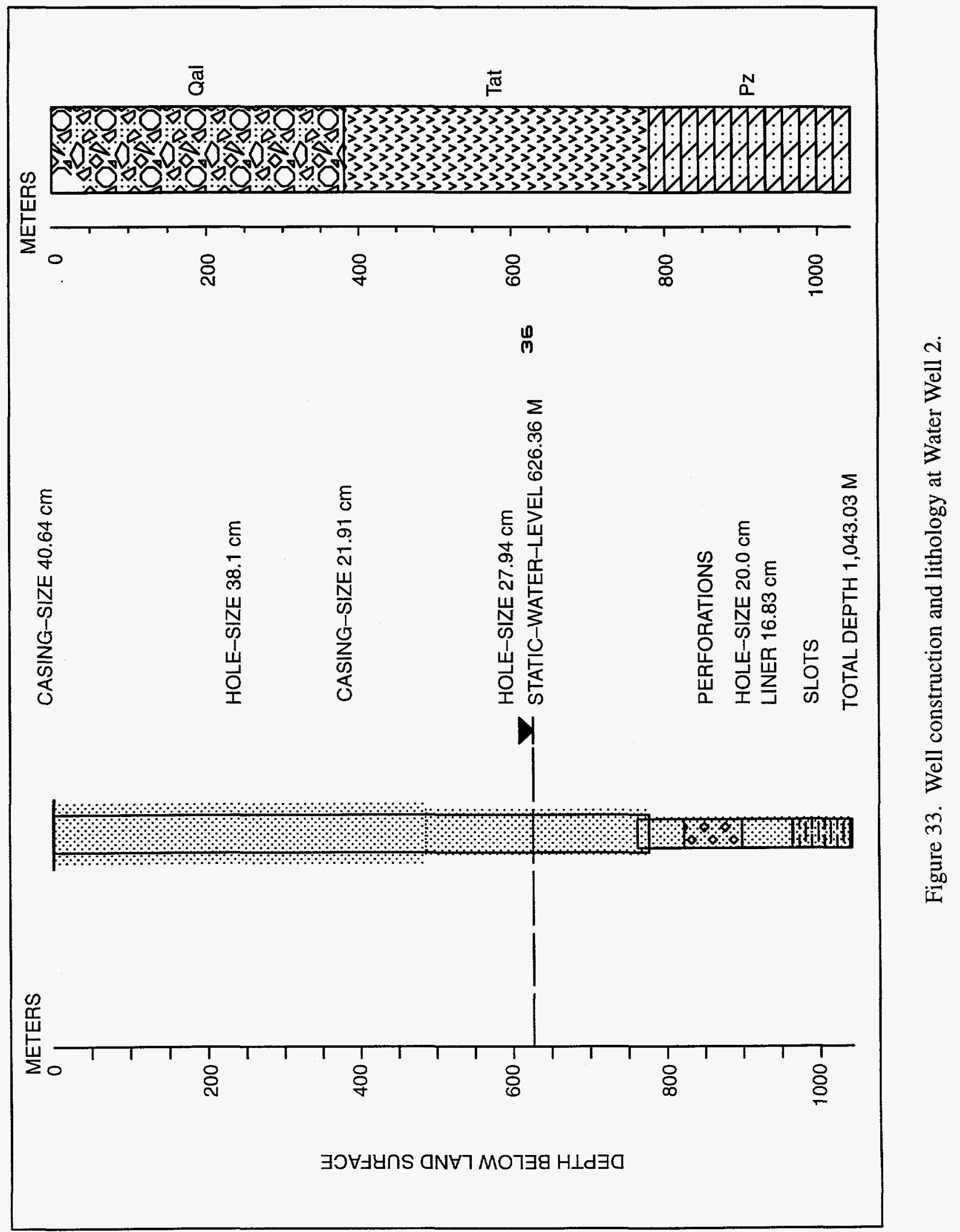




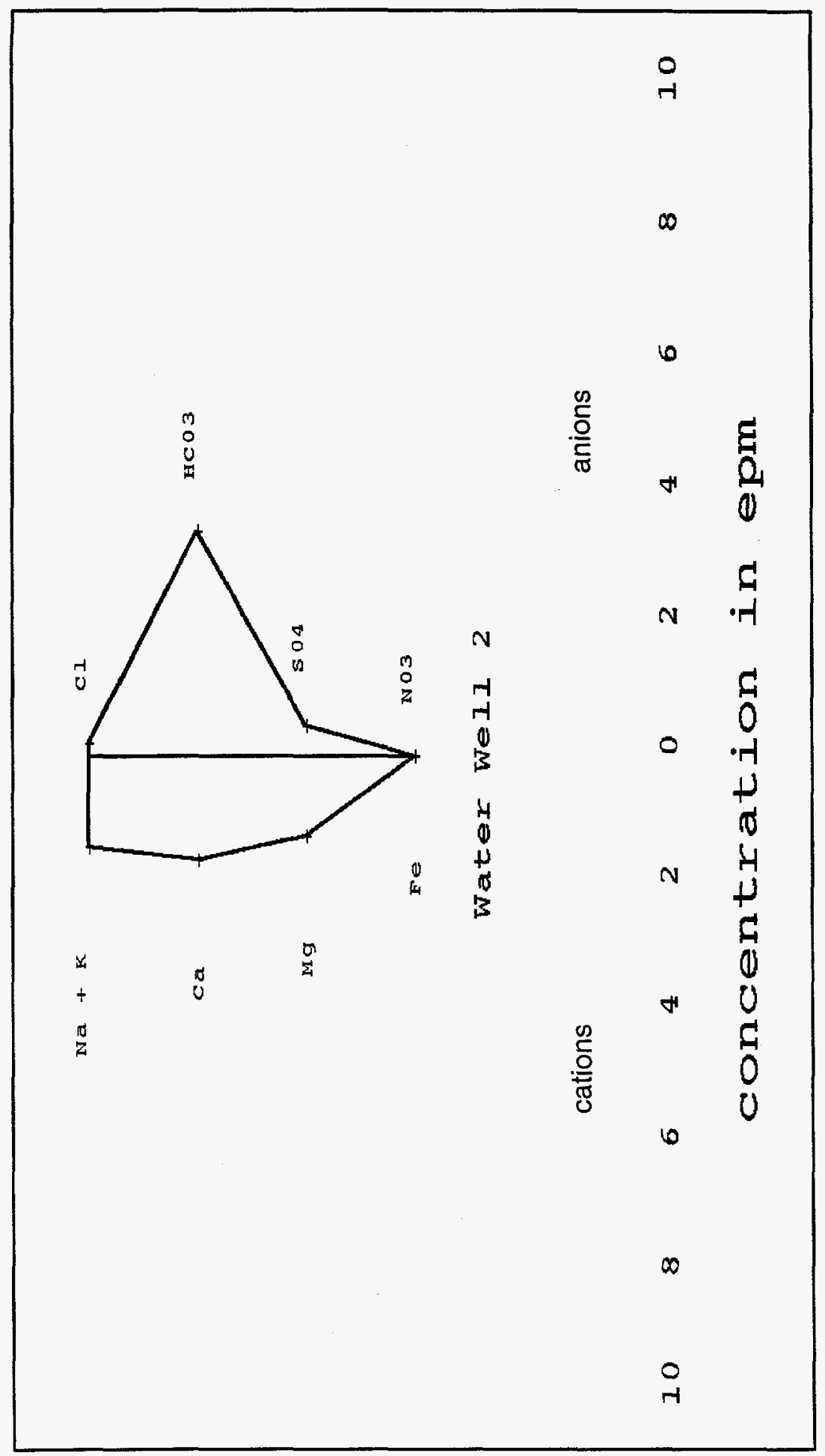

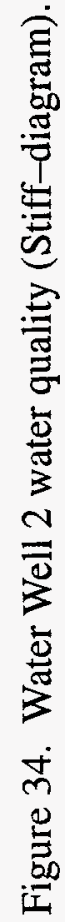




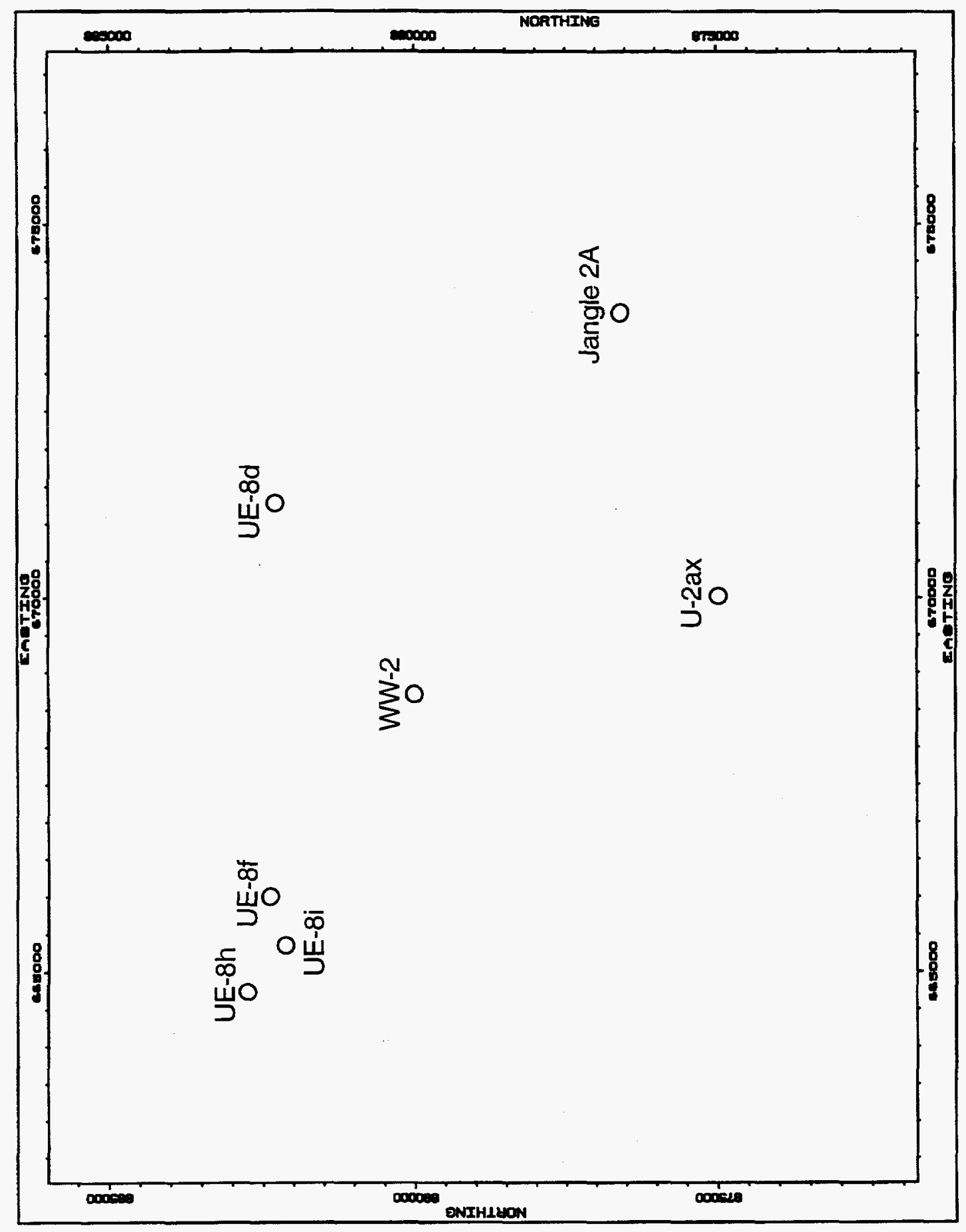

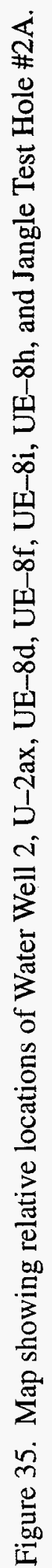




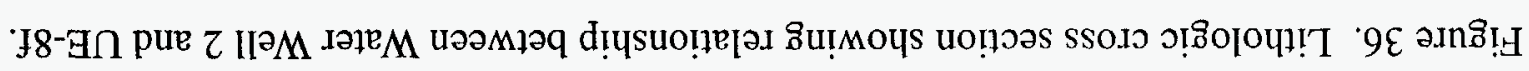

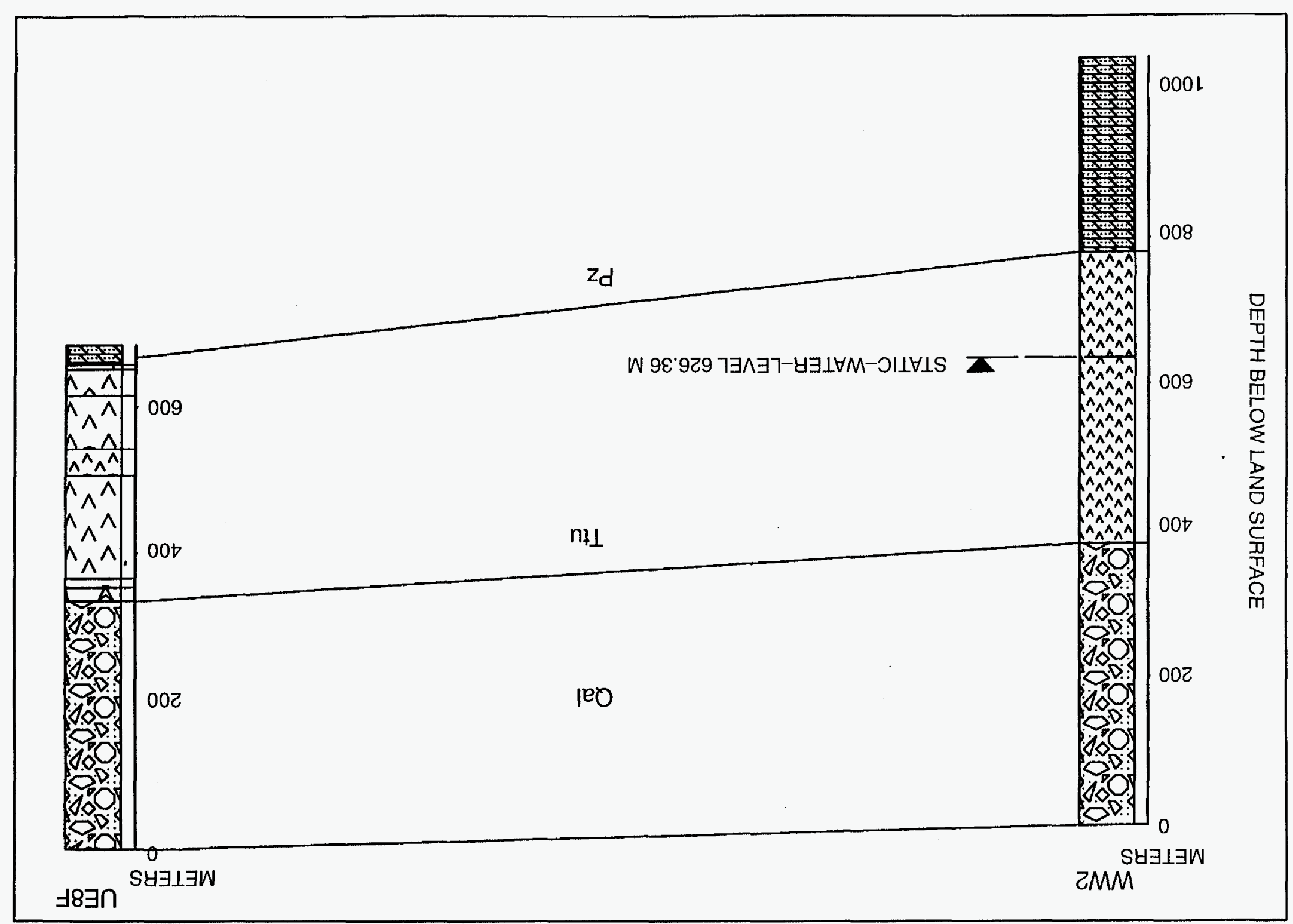




\section{Water Well U-20}

\section{Location}

Water Well U-20 is located on Pahute Mesa in the Alkali Flat-Furnace Creek Ranch subbasin (Figure 5). Potentiometric data (Winograd and Thordarson, 1975) indicated the general direction of groundwater flow in the area of Water Well U-20 to be from the northeast to the southwest (Figure 3). Land surface elevation at the well site is $1971.4 \mathrm{~m} \mathrm{MSL}$.

\section{Construction/Completion}

Water Well U-20 (Figure 37) was drilled in 1982 to a total depth of $996.1 \mathrm{~m}$. A 55.9-cm-diameter borehole was drilled to $818.1 \mathrm{~m}$, followed by a $44.4-\mathrm{cm}$-diameter borehole to total depth. The well was completed with 34-cm-diameter casing (slotted from 692.2 to $925.1 \mathrm{~m}$ ) set to a depth of $975 \mathrm{~m}$. This casing was not cemented within the well.

\section{Hydrogeology}

Fluid level within the well is reported at $620.3 \mathrm{~m}$ below land surface. NTS Site Maintenance Department records (unpublished) indicate a specific capacity of $7.4 \mathrm{~m}^{3} / \mathrm{day} / \mathrm{m}$ of drawdown at a discharge rate of $1526 \mathrm{~m}^{3} /$ day.

Water production from Water Well U-20 originates primarily from fractured rhyolite lava flows of the Tuffs and Rhyolites of Area 20 stratigraphic unit penetrated by the wellbore (Figure 40). Water quality data (Chapman and Lyles, 1993) from Water Well U-20 indicate a $\mathrm{Na}+\mathrm{K}+\mathrm{HCO}_{3}$ type water typical of volcanic aquifers (Figure 38).

\section{Proximity to Underground Nuclear Tests and Existing Wells}

Eight underground nuclear tests (U-20ac, U-20a, U-20b, U-20n, U-20bf, U-20bd, U-20ay, and U-20ai) have been conducted near (within $25 \mathrm{~m}$ ) or below the water table, and two wells (UE-20n\#1 and UE-20bh\#1) are located within $2 \mathrm{~km}$ of Water Well U-20 (Figure 39). All of these tests and wells, except U-20bd, are located downgradient or along near equal potentiometric gradient from Water Well U-20. U-20bd is located $1.4 \mathrm{~km}$ upgradient from Water Well U-20.

The underground test conducted in emplacement hole U-20bd was detonated approximately $50 \mathrm{~m}$ below the water table. The slotted interval in Water Well U-20 is located from 72 to $305 \mathrm{~m}$ below the water table (Figure 40). Although U-20bd is located a substantial distance upgradient from Water Well U-20, contamination of Water Well U-20 due to groundwater flow from U-20bd may be a possibility. Sampling of Water Well U-20 on a regular basis could provide valuable information on contaminate transport on Pahute Mesa.

\section{Water Well UE-19c}

\section{Location}

Water Well UE-19c is located on Pahute Mesa in the Alkali Flat-Furnace Creek Ranch subbasin (Figure 5). Potentiometric data (Winograd and Thordarson, 1975) indicate the general direction of groundwater flow in the area of Water Well UE-19c is from the east to the west (Figure 3). Land surface elevation at the well site is $2143.7 \mathrm{~m} \mathrm{MSL}$. 


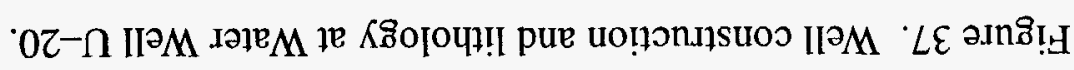

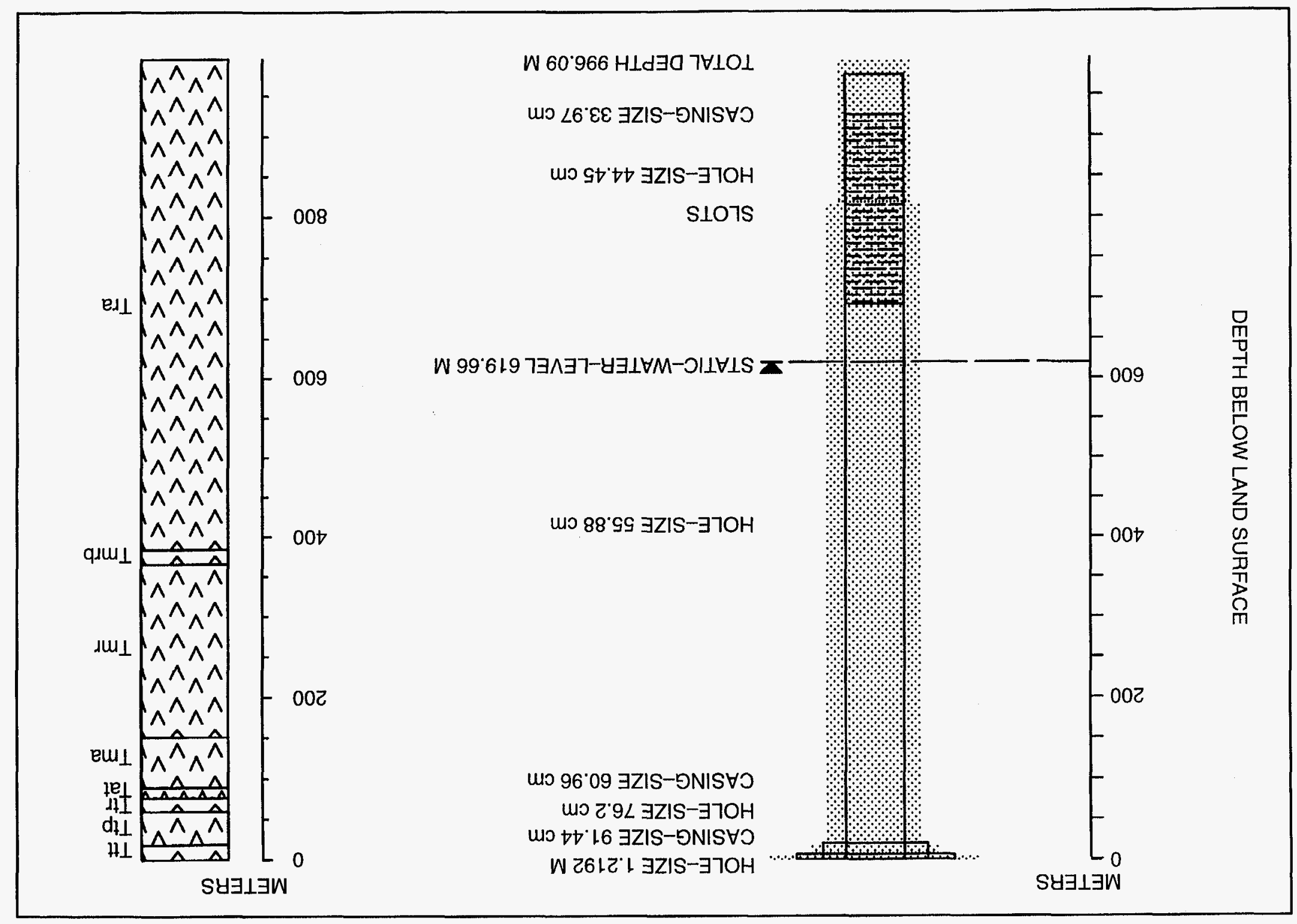




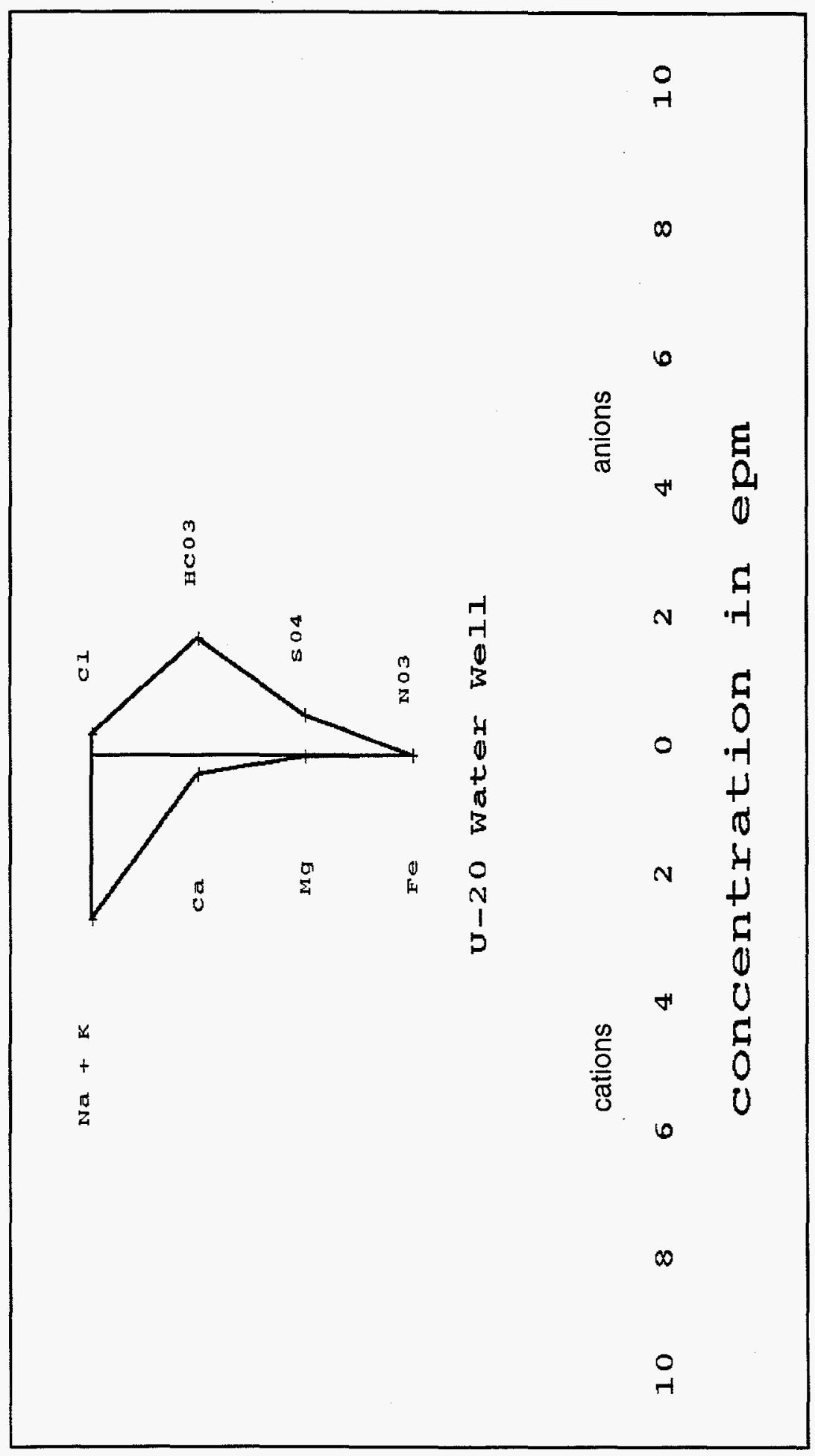

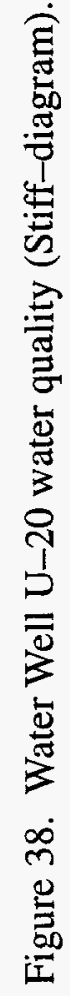




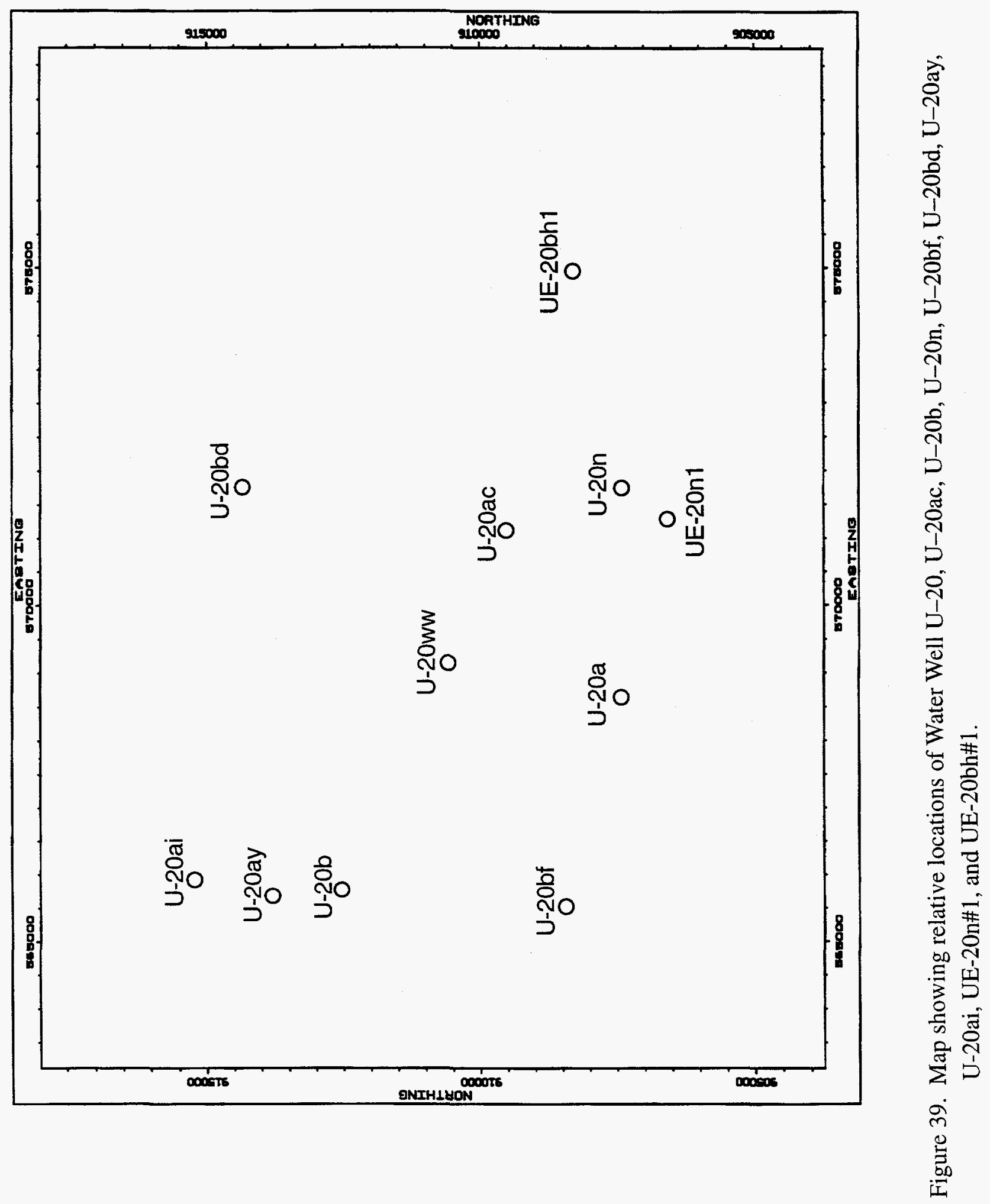




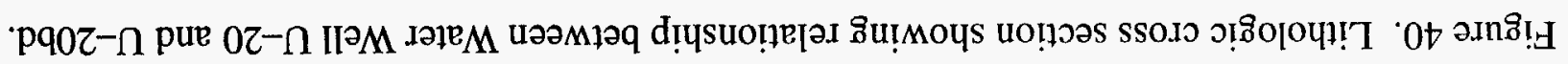

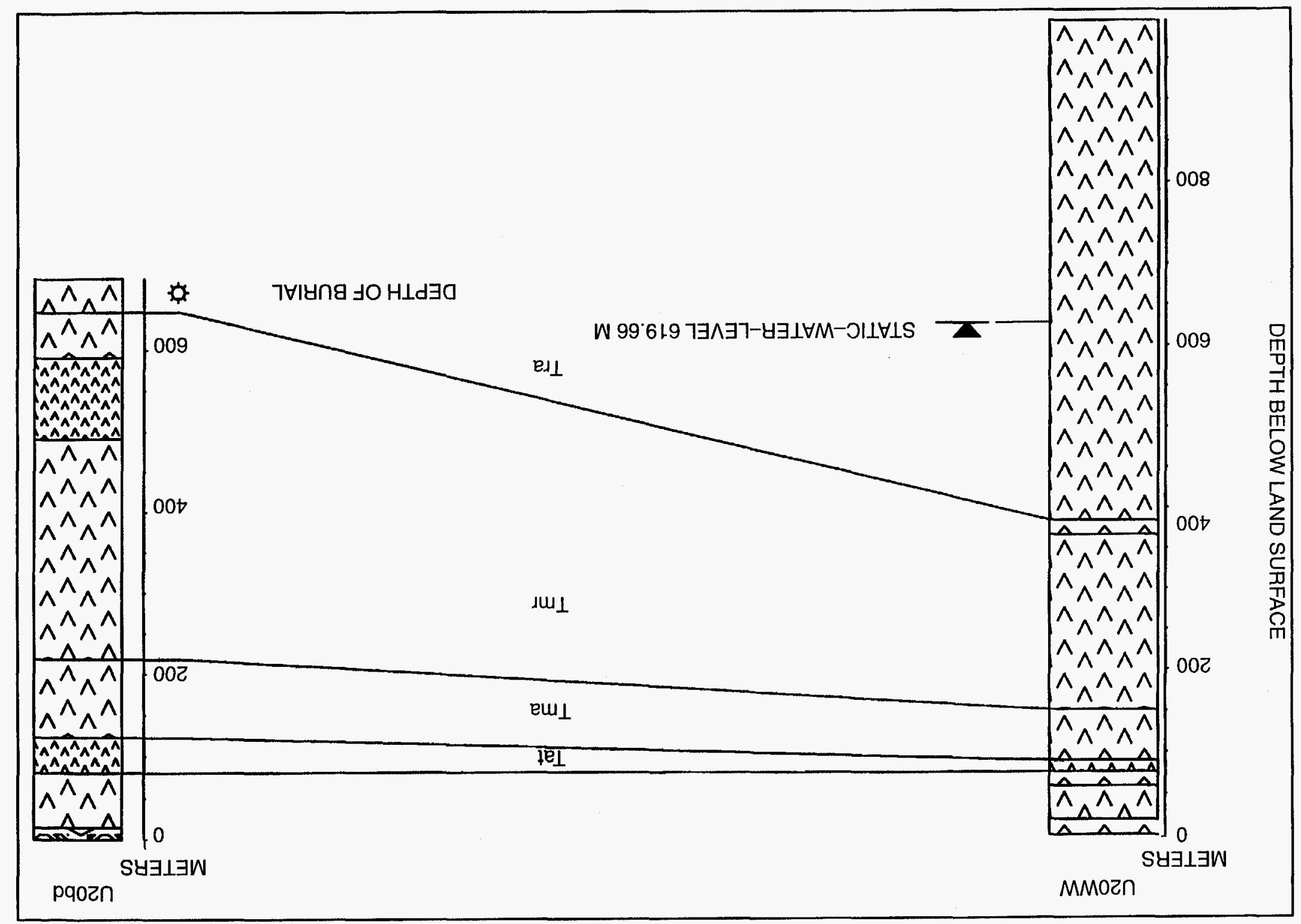




\section{Construction/Completion}

Water Well UE-19c (Figure 41) was drilled in 1964 to a total depth of $2587.5 \mathrm{~m}$. During construction of the well, 34-cm-diameter casing was set within the well to a depth of $737.9 \mathrm{~m}$. The annular space between this casing and the wellbore was cemented to the surface. Below the casing, a $25.1-\mathrm{cm}$-diameter hole was drilled to $793.7 \mathrm{~m}$. Drilling continued with a $25.1-\mathrm{cm}$-diameter hole until drilling was terminated due to the loss of drill pipe near the bottom of the hole. The top of the lost pipe is approximately $2276.3 \mathrm{~m}$ below land surface. Caliper logs conducted in Water Well UE-19c in March 1976 indicated casing damage has occurred in three places within the 34-cm-diameter casing: at $127.7 \mathrm{~m}$, the inside diameter of the casing is reduced to $26.7 \mathrm{~cm}$; at 535.8 $\mathrm{m}$ to $29.2 \mathrm{~cm}$; and at $586.7 \mathrm{~m}$ to $21.6 \mathrm{~cm}$. This casing damage is most likely the result of nearby underground nuclear testing.

\section{Hydrogeology}

On November 16,1992, DRI personnel conducted fluid level and total depth checks in Water Well UE-19c; temperature and electrical conductivity logs of the saturated interval were also obtained. Fluid level in the well was measured at $714.7 \mathrm{~m}$ below land surface. Total depth was measured at $922 \mathrm{~m}$.

NTS Site Maintenance Department production records (unpublished) indicate a specific capacity of approximately $73 \mathrm{~m}^{3} / \mathrm{day} / \mathrm{m}$ of drawdown at a discharge rate of $1962 \mathrm{~m}^{3} /$ day. Estimated mean transmissivity for Water Well UE-19c is $149 \mathrm{~m}^{2} /$ day (Blankennagel and Weir, 1973).

Water quality data (Chapman and Lyles, 1993) from Water Well UE-19c indicate a $\mathrm{Na}+\mathrm{K}+\mathrm{HCO}_{3}$ type water typical of volcanic aquifers (Figure 43). Hydrologic tests conducted during construction of Water Well UE-19c indicated the major water production to be from a rhyolite lava interval (portion of Tuffs and Rhyolites of Area 20 stratigraphic unit) present from approximately 742.2 to $951 \mathrm{~m}$ (Figure 44). Below this aquifer is a tuff unit. Repeated bridging of the hole occurred within this tuff unit at approximately the depth at which the borehole diameter is reduced from 31.1 to $25.1 \mathrm{~cm}$.

\section{Proximity to Underground Nuclear Tests and Existing Wells}

One underground nuclear test, U-19c, has been conducted near (within $25 \mathrm{~m}$ ) or below the water table within $2 \mathrm{~km}$ of Water Well UE-19c (Figure 46). U-19c is located $0.605 \mathrm{~km}$ southeast of Water Well UE-19c. The underground test conducted in emplacement hole U-19c was detonated just above the water table. The major water production in Water Well UE-19c is from a unit located just below the water table (Figure 47). Although Water Well UE-19c appears to be located a substantial distance from and perpendicular to the direction of groundwater flow from U-19c, the groundwater flow patterns in the volcanic units on Pahute Mesa are not well enough understood to rule out possible contamination of Water Well UE-19c due to groundwater flow from U-19c. Sampling of Water Well UE-19c on a regular basis could provide valuable information on contaminate transport on Pahute Mesa. 


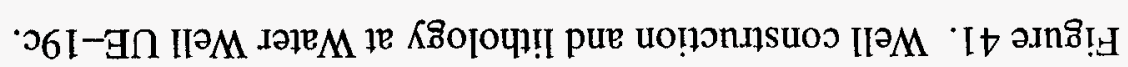

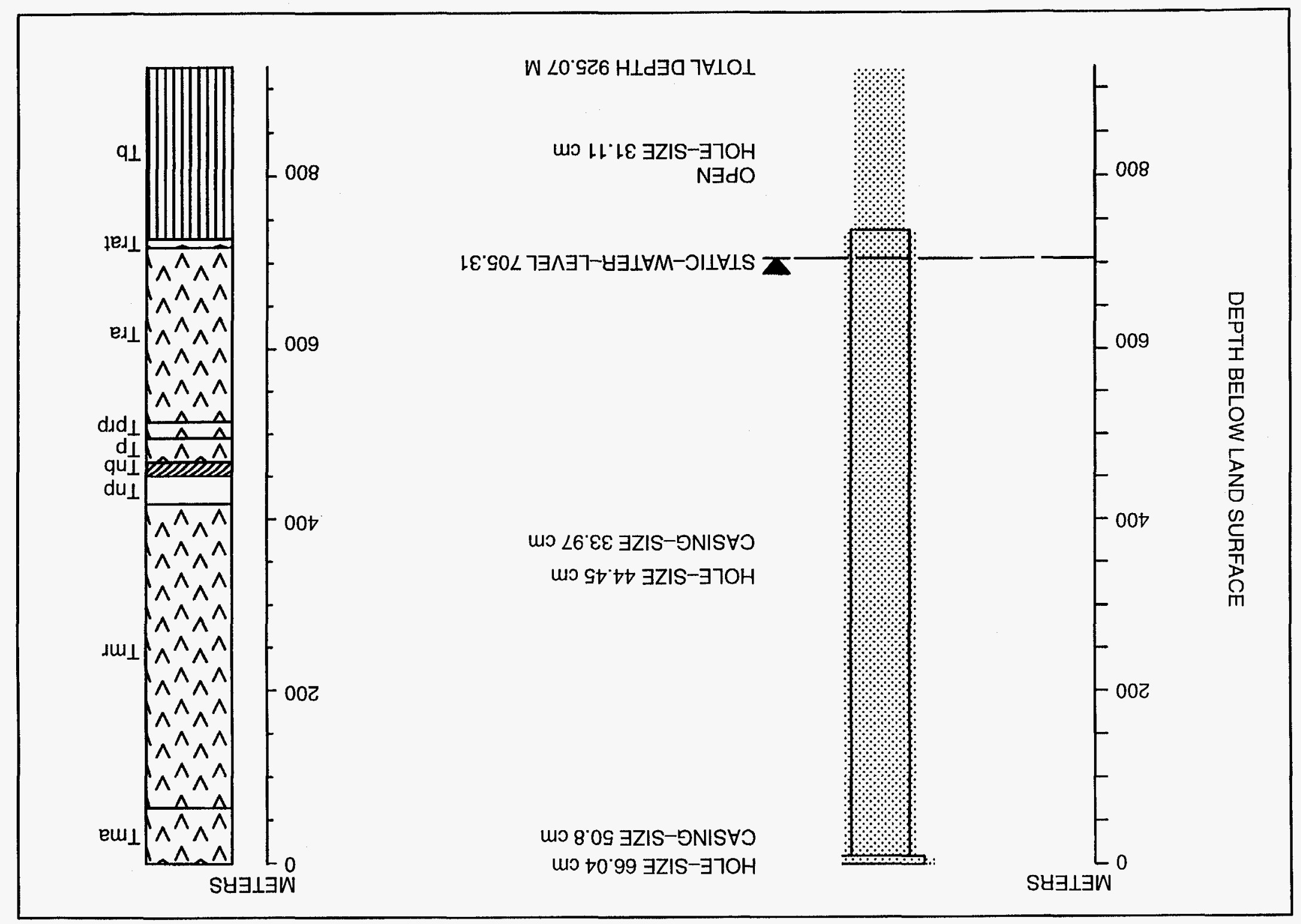




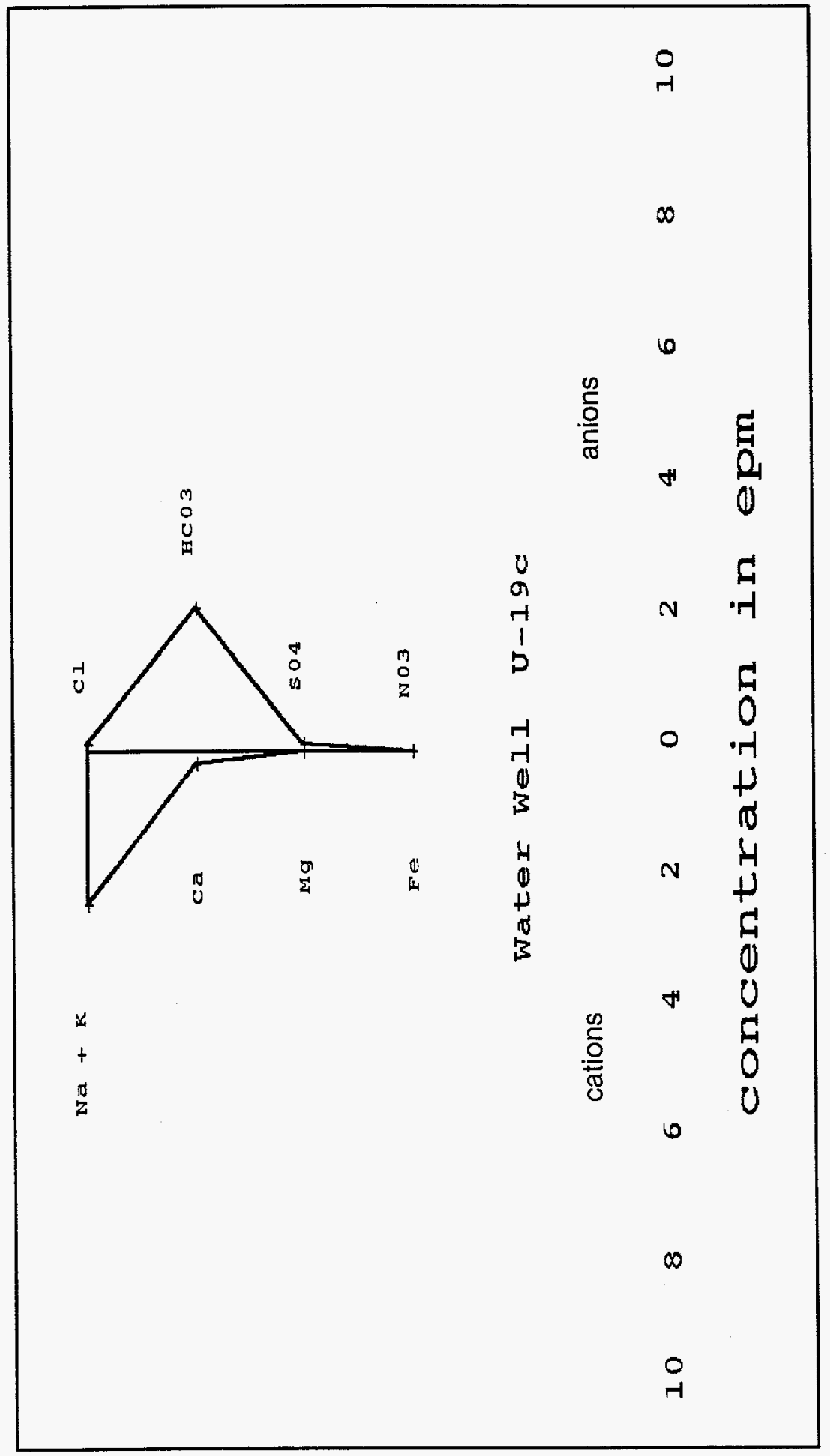

है 


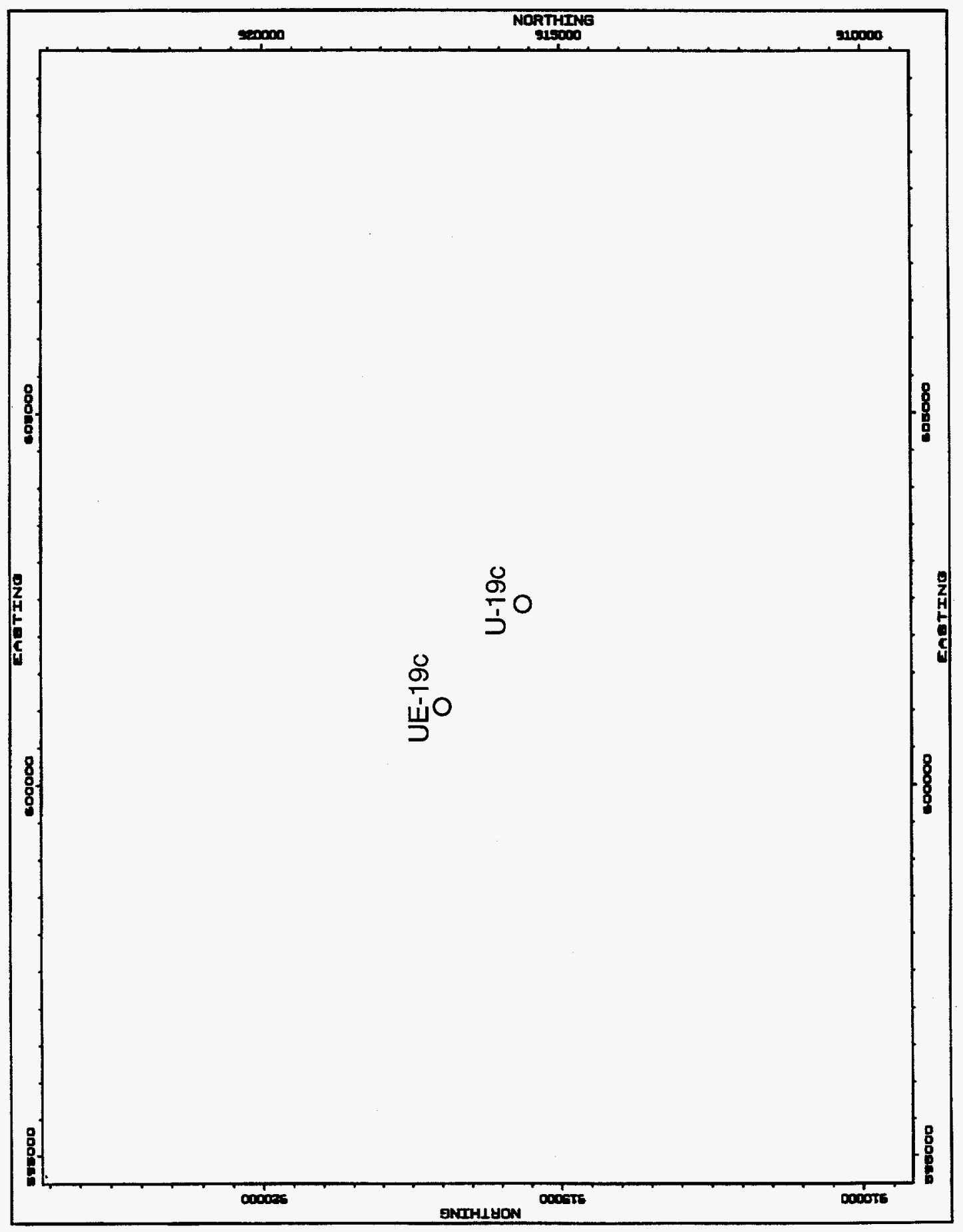

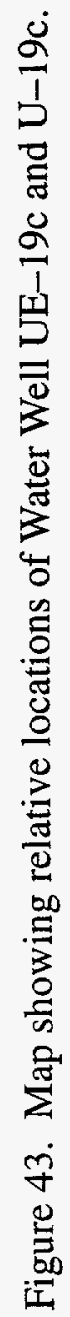




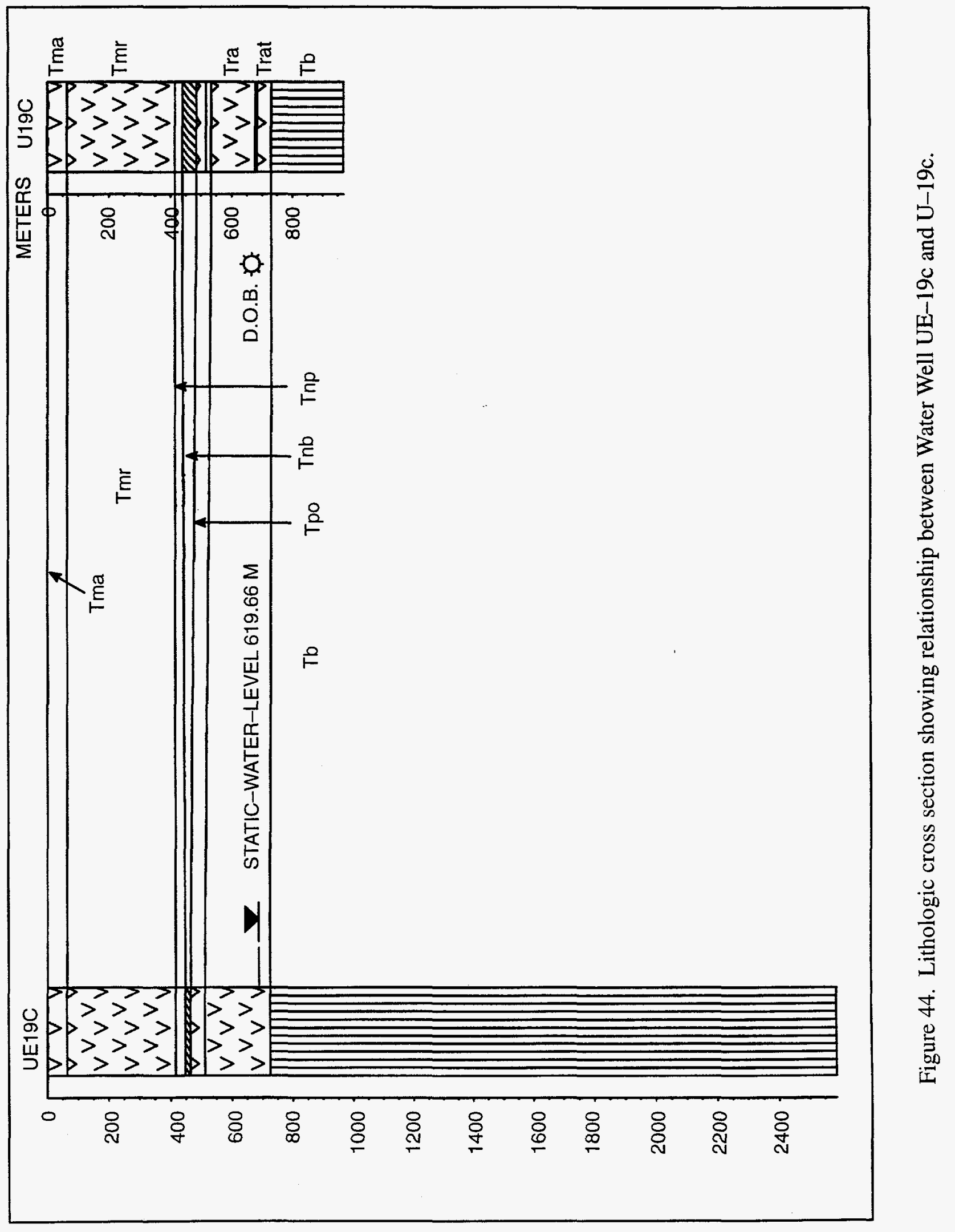




\section{REFERENCES}

Blankennagel, R.K. and J.E. Weir, Jr., 1973. Geohydrology of the Eastern Part of Pahute Mesa, Nevada Test Site, Nye County, Nevada. U.S. Geological Survey Professional Paper 712-B, 35 p.

Chapman J.B. and B. Lyles, 1993. Groundwater chemistry at the Nevada Test Site: Data and preliminary interpretations, Desert Research Institute Publication No. 45100.

Claassen, H.C., 1973. Water quality and physical characteristics of Nevada Test Site water-supply wells: U.S. Geological Survey, USGS-474-158.

Schoff, S.L. and J.E. Moore, 1964. Chemistry and movement of groundwater, Nevada Test Site, U.S. Geological Survey Report TEI-838.

Waddell, R.K., J.H. Robison and R.K. Blankennagel, 1984. Hydrology of Yucca Mountain and vicinity, Nevada-California--Investigative results through mid-1983: U.S. Geological Survey Water-Resources Investigations Report 84-4267, 35 p.

White, A.F., 1979. Geochemistry of groundwater associated with tuffaceous rocks, Oasis Valley, Nevada: U.S. Geological Survey Professional Paper 712-E, 25 p.

Winograd, I.J. and W. Thordarson, 1975. Hydrogeologic and hydrochemical framework, south-central Great Basin, Nevada-California, with special reference to the Nevada Test Site: U.S. Geological Survey Professional Paper 712-C, C1-C126. 
APPENDIX A

LITHOLOGIC SYMBOLS USED IN CROSS SECTIONS AND WELL DIAGRAMS

LITHOLOGIC SYMBOL

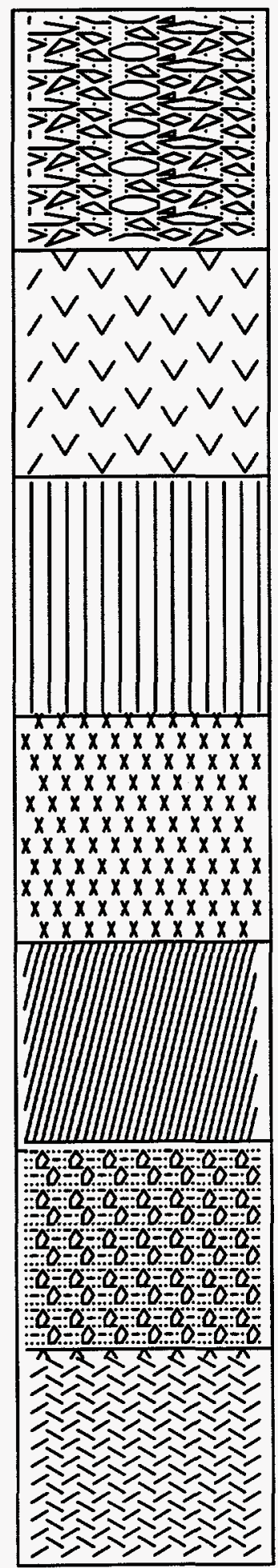

GENERAL ROCK TYPE

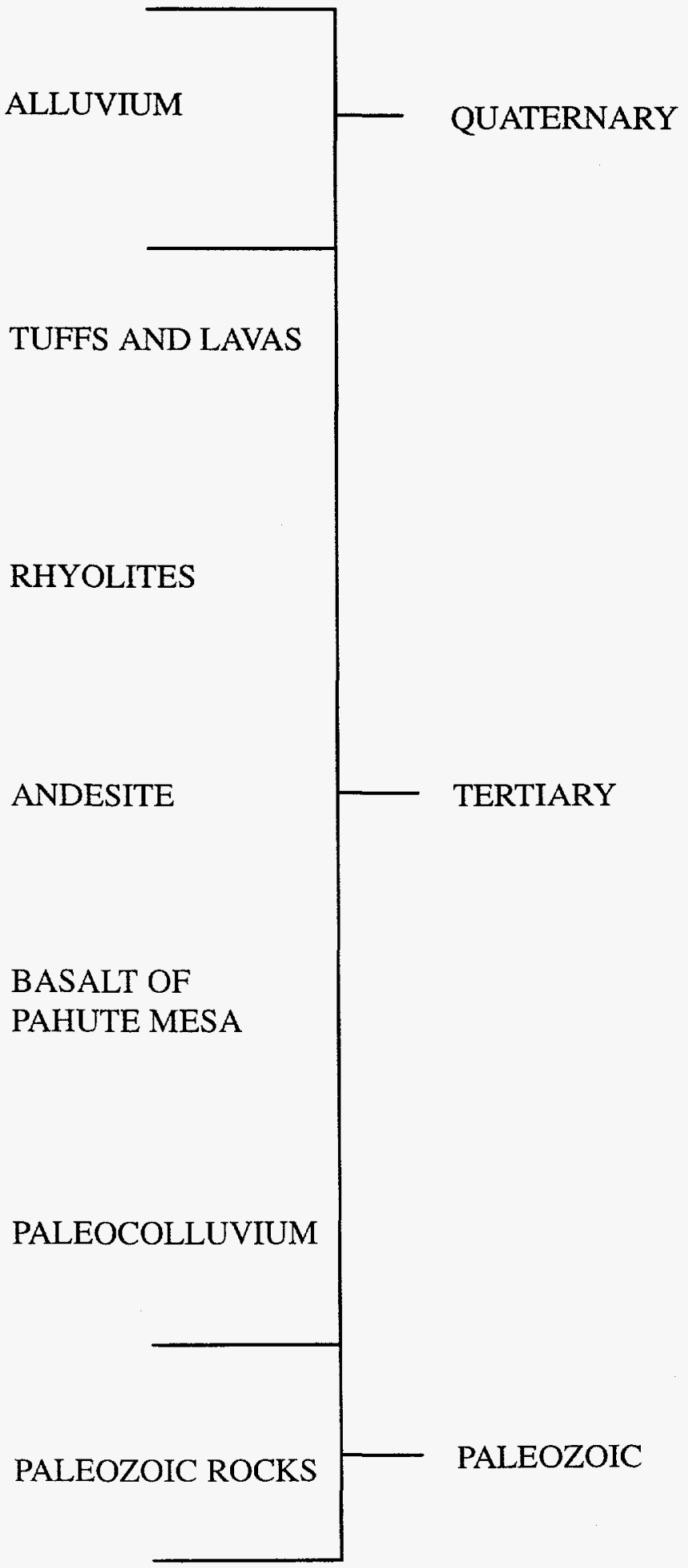




\section{APPENDIX B}

STRATIGRAPHIC NOMENCLATURE USED IN HOLE DIAGRAMS

\begin{tabular}{ll}
\hline \hline Pz & Paleozoic Rocks - Unidentified \\
Pzc & Paleozoic Carbonates \\
Pzq & Paleozoic Quartzites \\
Pzt & Colluvium \\
Qal & Alluvium, Undivided \\
Tab & Bedded Tuffs (Peralkaline) \\
Tac & Calico Hills Rhyolite \\
Tacu & Calico Hills Rhyolite, Mafic-poor \\
Tan & Ash-fall and Nonwelded Tuff (Post Timber Mountain) \\
Tat & Vitric Bedded, Ash-fall, and Reworked Tuff (Post Timber Mountain) \\
Tb & Belted Range Rhyolite \\
Tbdx & Landslide Breccia \\
Tbg & Bedded Grouse Canyon Tuff \\
Tbgb & Comendite of Basket Valley \\
Tbt & Tub Spring Tuff \\
Tc & Crater Flat Tuff, Undifferentiated \\
Tca & Andesite \\
Tcb & Bullfrog Tuff \\
Tcf & Crater Flat Tuff \\
Tcpu & Mafic-poor Prow Pass \\
Tf & Fraction Tuff \\
Tfbw & Beatty Wash Rhyolite \\
TlC & Paleocolluvium (Tuffaceous) \\
Tma & Ammonia Tanks Tuff \\
Tmab & Ammonia Tanks Tuff, Bedded \\
Tmal & Ammonia Tanks Tuff, Lower \\
Tmau & Timmonia Tanks Tuff, Upper \\
Tmb & Timber Mountain Bedded Tuff \\
Tmr & \\
Tmrb & Timber Mountain Tuff, Rainier Mesa Member, Lower \\
Tmrl & Tmpr \\
Tnb & \\
\hline \hline & Aahinier Mesa Rhyolite \\
\hline
\end{tabular}


APPENDIX B

STRATIGRAPHIC NOMENCLATURE USED IN HOLE DIAGRAMS (CONT.)

\begin{tabular}{ll}
\hline \hline Tnp & Pool Unit \\
Tnqr & Quartz Rhyolite of Scrugham Peak Quad \\
Tot1 & Pre-fraction Bedded Tuffs, Undifferentiated \\
Tot2 Undiff. & Pre-Redrock Valley Post-fraction Bedded Tuffs \\
Tp & Paintbrush Tuff \\
Tpc & Paintbrush Tuff, Tiva Canyon Member \\
Tppr & Pyroxene Rhyolite of Scrugham Peak Quad \\
Tprp & Pre-Pah Canyon Rhyolite \\
Tpt & Topopah Spring Tuff \\
Tptp & Topopah Spring Member of Pahute Mesa \\
Tra & Tuffs and Lavas of Area 20 \\
Trab & Area 20 Tuffs and Lavas, Bedded and Ash Flows \\
Tral & Area 20 Tuffs and Lavas, Lower Lava Unit \\
Trat & Area 20 Tuffs and Lavas, Lithic-rich Tuff \\
Trq & Rhyolite Lava of Quartet Dome \\
Trv & Redrock Valley Tuff \\
Tt & Thirsty Canyon Tuffs \\
Tt1 & Tunnel Bed 1 \\
Tt2 & Tunnel Bed 2 \\
Tt3 & Tunnel Beds, Unit 3 \\
Tt3BC & Tunnel Beds, Subunit 3bc \\
Tt4 & Tunnel Beds, Unit 4 \\
Tt4E & Tunnel Beds, Subunit 4e \\
Ttl & Thirsty Canyon, Lower Tuff \\
Ttp & Thirsty Canyon, Pahute Mesa Member \\
Ttr & Thirsty Canyon, Rocket Wash Member \\
Ttt & Thirsty Canyon, Trail Ridge Member \\
Ttu & Tunnel Beds, Undifferentiated \\
Tw & Wahmonie Tuff \\
Tx Undiff. & Pre-Rainier Mesa, Post-Wahmonie Bedded Tuffs \\
Tyf & Yucca Flat Tuff \\
Unk &
\end{tabular}




\section{DISTRIBUTION}

Bob Bangerter

Environmental Restoration Division

Nevada Operations Office

U.S. Department of Energy

P.O. Box 98518

Las Vegas, NV 89193-8518

Dave Beck

U.S. Geological Survey

Water Resources Division

6770 S. Paradise Rd.

Las Vegas, NV 89119

Ron Baugh

Bechtel Nevada Corporation

P.O. Box 98521

Las Vegas, NV 89193-8521

Joanne M. Bradbery, Director Contract Management Division

Nevada Operations Office

U.S. Department of Energy

P.O. Box 98518

Las Vegas, NV 89193-8518

Beverly Colbert

Contract Management Division

Nevada Operations Office

U.S. Department of Energy

P.O. Box 98518

Las Vegas, NV 89193-8518

Lee Davisson

Nuclear Chemistry Division

Lawrence Livermore National Laboratory

P.O. Box 808 , L-237

Livermore, CA 94550

Brian Dozier

Bechtel Nevada Corporation

P.O. Box 98521

Las Vegas, NV 89193-8521
Doug Duncan (4)

Environmental Protection Division

Nevada Operations Office

U.S. Department of Energy

P.O. Box 98518

Las Vegas, NV 89193-8518

Dennis Farmer

Radiation Sciences Laboratory

Office of Radiation and Indoor Air

U.S. Environmental Protection Agency

P.O. Box 98517 , M/S 513

Las Vegas, NV 89193-8517

Larry Franks

Nevada State Health Department

Radiological Health Section

620 Belrose Avenue

Las Vegas, NV 89158

Wayne Glines

Bechtel Nevada Corporation

P.O. Box 98521

Las Vegas, NV 89193-8521

Laura Helfel

State of Nevada

Department of Conservation

and Natural Resources

Division of Environmental Protection

333 W. Nye Lane

Carson City, NV 89710

Kenneth Hoar, Director

Environmental Protection Division

Nevada Operations Office

U.S. Department of Energy

P.O. Box 98518

Las Vegas, NV 89193-8518

Deborah Howard

Environmental Protection Division

Nevada Operations Office

U.S. Department of Energy

P.O. Box 98518

Las Vegas, NV 89193-8518 
Kathy Izell

Assistant Manager for Technical Services

Nevada Operations Office

U.S. Department of Energy

P.O. Box 98518

Las Vegas, NV 89193-8518

Roger Jacobson

Desert Research Institute

Water Resources Center

P.O. Box 19040

Las Vegas, NV 89132-0040

Marjory Jones

Desert Research Institute

Water Resources Center

P.O. Box 60220

Reno, NV 89506-0220

Jim Kannard

Bechtel Nevada Corporation

P.O. Box 98521

Las Vegas, NV 89193-8521

Annie Kersting

Lawrence Livermore National Laboratory

Isotope Sciences Division

L-213

P.O. Box 808

Livermore, CA 94550

Randy Laczniak

U.S. Geological Survey

Water Resources Division

6770 S. Paradise Rd.

Las Vegas, NV 89119

Steve Mellington, Director

Environmental Restoration Division

Nevada Operations Office

U.S. Department of Energy

P.O. Box 98518

Las Vegas, NV 89193-8518
Leslie A. Monroe

Environmental Protection Division

Nevada Operations Office

U.S. Department of Energy

P.O. Box 98518

Las Vegas, NV 89193-8518

Ken Rehfeldt

Geotrans, c/o IT

4330 Valley View

Suite 112, MS-439

Las Vegas, NV 89103

David K. Smith

Isotopes Sciences Division

Lawrence Livermore National Laboratory

P.O. Box 808, M/S L231

Livermore, CA 94550

Nick Stellevato

Nuclear Waste Repository Project Office

P.O. Box 675

Mercury, NV 89023

Bonnie Thompson

Environmental Protection Division

Nevada Operations Office

U.S. Department of Energy

P.O. Box 98518

Las Vegas, NV 89193-8518

Joe Thompson

Los Alamos National Laboratory

INC-11, MS J514

P.O. Box 1663

Los Alamos, NM 87545

Doug Trudeau

U.S. Geological Survey

Water Resources Division

6770 S. Paradise Rd.

Las Vegas, NV 89119

Steve Wiel

Bechtel Nevada Corporation

P.O. Box 98521

Las Vegas, NV 89193-8521 
Janet Wiley

International Technology Corporation $4330 \mathrm{~S}$. Valley View

Suite 114

Las Vegas, NV 89103

Annie Kelley

State Documents Department

Nevada State Library

Capitol Complex

Carson City, NV 89710

Archives

Getchell Library

University of Nevada, Reno

Beverly Carter

MacKay School of Mines Library

University of Nevada, Reno

Document Section, Library

University of Nevada, Las Vegas

4505 Maryland Parkway

Las Vegas, NV 89154

Library (Stead)

Desert Research Institute

P.O. Box 60220

Reno, Nevada 89506-0220
Library

IT Corporation

4330 S. Valley View

Suite 114

Las Vegas, NV 89103

ATTN: Toni Miller

Library

Southern Nevada Science Center

Desert Research Institute

P.O. Box 19040

Las Vegas, NV 89132-0040

Public Reading Facility

Bechtel Nevada Corporation

P.O. Box 98521

Las Vegas, NV 89193-8521

Technical Information Resource Center

Nevada Operations Office

U.S. Department of Energy

P.O. Box 98518

Las Vegas, NV 89193-8518

Librarian

Water Resources Center Archives

$4100^{\prime} B$ Brien Hall

University of California

Berkeley, CA 94720-1718

Office of Scientific and Technical Information

U.S. Department of Energy

P.O. Box 62

Oak Ridge, TN 37831-9939 